In cooperation with the Arkansas Natural Resources Commission, the Arkansas Geological Commission, and the Louisiana Department of Transportation and Development

\title{
Status of Water Levels and Selected Water-Quality Conditions in the Sparta-Memphis Aquifer in Arkansas and the Status of Water Levels in the Sparta Aquifer in Louisiana, Spring 2005
}

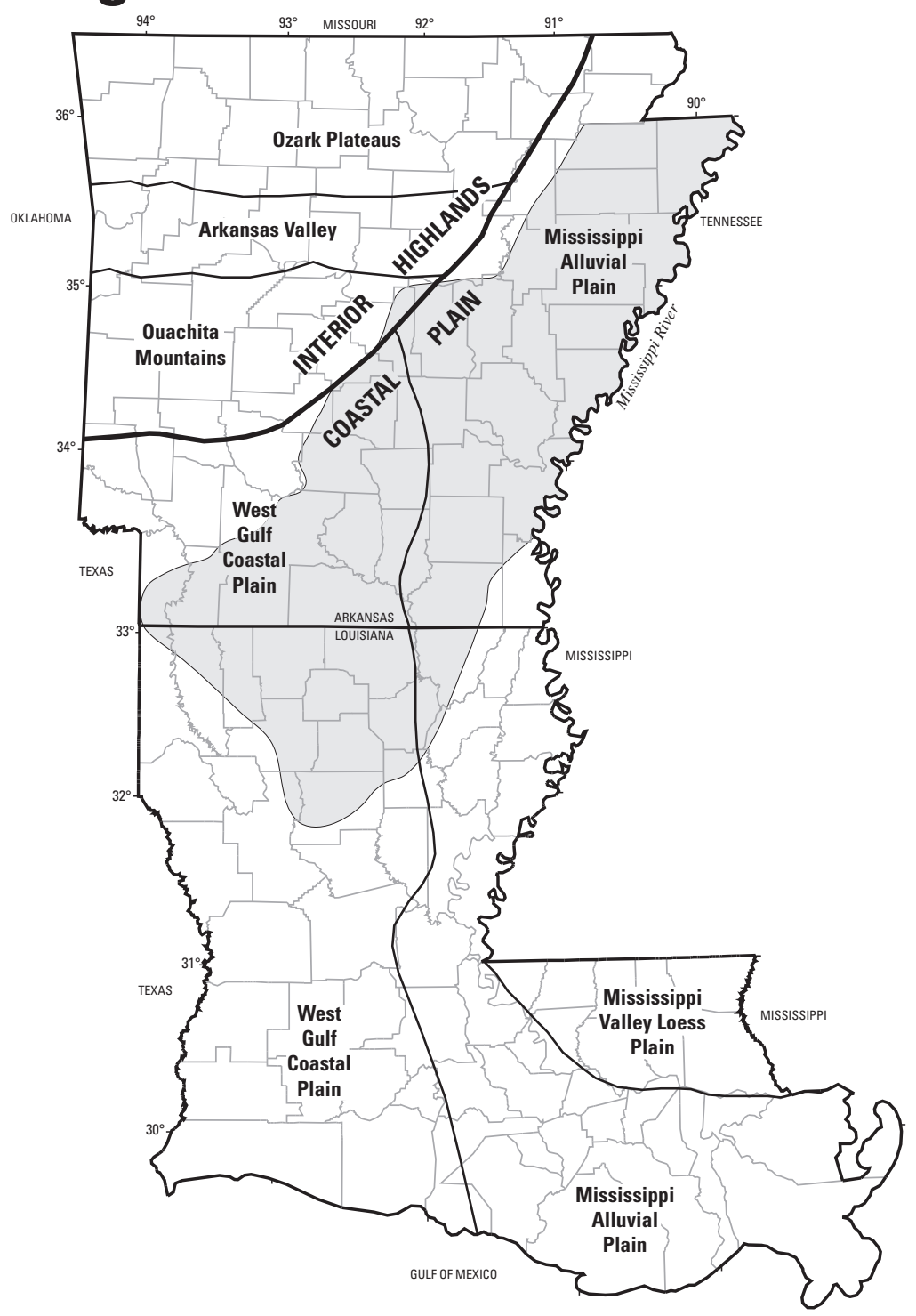

Scientific Investigations Report 2007-5029 


\section{Status of Water Levels and Selected Water-Quality Conditions in the Sparta- Memphis Aquifer in Arkansas and the Status of Water Levels in the Sparta Aquifer in Louisiana, Spring 2005}

By T.P. Schrader and J.S. Jones

In cooperation with the Arkansas Natural Resources Commission, the Arkansas

Geological Commission, and the Louisiana Department of Transportation and Development

Scientific Investigations Report 2007-5029 


\section{U.S. Department of the Interior DIRK KEMPTHORNE, Secretary}

\section{U.S. Geological Survey \\ Mark D. Myers, Director}

\section{U.S. Geological Survey, Reston, Virginia: 2007}

For product and ordering information:

World Wide Web: http://www.usgs.gov/pubprod

Telephone: 1-888-ASK-USGS

For more information on the USGS--the Federal source for science about the Earth, its natural and living resources, natural hazards, and the environment:

World Wide Web: http://www.usgs.gov

Telephone: 1-888-ASK-USGS

Any use of trade, product, or firm names is for descriptive purposes only and does not imply endorsement by the U.S. Government.

Although this report is in the public domain, permission must be secured from the individual copyright owners to reproduce any copyrighted materials contained within this report.

Suggested citation:

Schrader, T.P., and Jones, J.S., 2007, Status of water levels and selected water-quality conditions in the Sparta-Memphis aquifer in Arkansas and the status of water levels in the Sparta aquifer in Louisiana, spring 2005: U.S. Geological Survey Scientific Investigations Report 2007-5029, 66 p. 


\section{Contents}

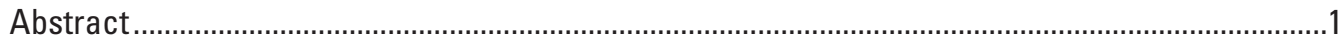

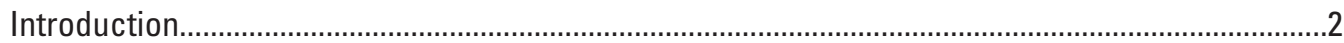

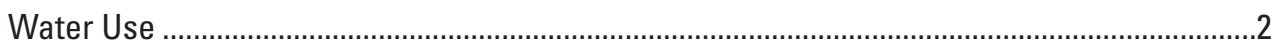

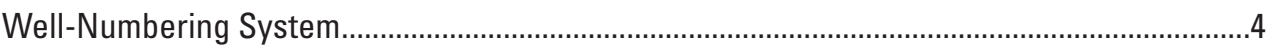

Methods

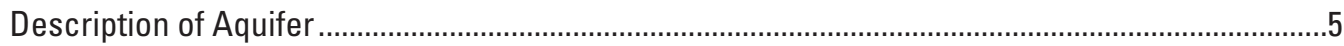

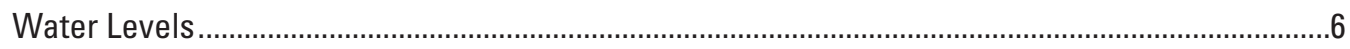

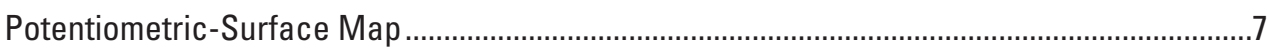

Water-Level Difference Map from 2001 to 2005....................................................................

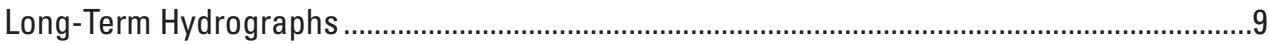

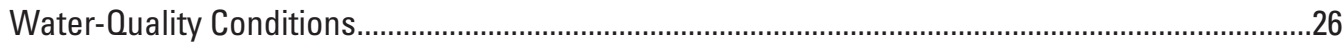

Summary.

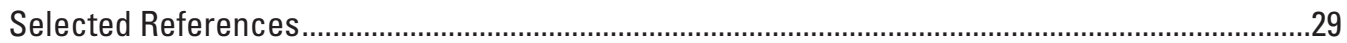

Appendix 1. Water-level data collected during spring 2005 from wells completed in the Sparta-Memphis aquifer in Arkansas and Louisiana........................................................32

Appendix 2. Difference in water level from 2001 to 2005 in the Sparta-Memphis aquifer in Arkansas and Louisiana ..............................................................................................50

Appendix 3. Specific conductance and temperature data collected from wells completed in the Sparta-Memphis aquifer in Arkansas, spring 2005......................................................63

\section{Plates}

[In pocket]

1. Map showing potentiometric surface of the Sparta-Memphis aquifer in Arkansas and Louisiana, spring 2005

2. Map showing water-level difference between 2001 to 2005 for the Sparta-Memphis aquifer in Arkansas and Louisiana

\section{Figures}

1. Map showing location of study area …….................................................................................

2. Graph showing water use in the Sparta-Memphis aquifer in Arkansas and Louisiana,

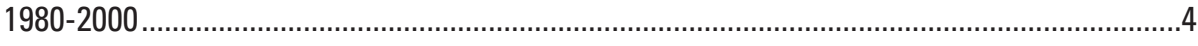

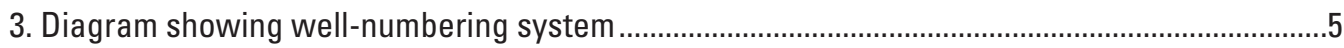

4. Graphs showing water-level hydrographs for selected wells completed in the SpartaMemphis aquifer in Arkansas and Louisiana................................................................11

5. Graph showing distribution of specific conductance in samples from wells screened in the Sparta-Memphis aquifer in Arkansas, 2005-2003..........................................................26 


\section{Tables}

1. Stratigraphic correlation of Louisiana and the north and south parts of Arkansas for the study area

2. Statistical summary of annual rise-decline in water level by county for wells in the Sparta-Memphis aquifer in Arkansas, 1981-2005.

\section{Conversion Factors, Vertical Datum, and Abbreviations}

\begin{tabular}{lcl}
\hline \multicolumn{1}{c}{ Multiply } & By & \multicolumn{1}{c}{ To obtain } \\
\hline foot (ft) & Length & \\
mile (mi) & 0.3048 & meter $(\mathrm{m})$ \\
\hline & 1.609 & kilometer $(\mathrm{km})$ \\
\hline foot per year (ft/yr) & Flow rate & \\
million gllons per day (Mgal/d) & 0.3048 & meter per year $(\mathrm{m} / \mathrm{yr})$ \\
\hline
\end{tabular}

Temperature in degrees Celsius $\left({ }^{\circ} \mathrm{C}\right)$ may be converted to degrees Fahrenheit $\left({ }^{\circ} \mathrm{F}\right)$ as follows:

$$
{ }^{\circ} \mathrm{F}=\left(1.8 \mathrm{x}^{\circ} \mathrm{C}\right)+32
$$

Vertical coordinate information is referenced to the National Geodetic Vertical Datum of 1929 (NGVD of 1929).

Horizontal coordinate information is referenced to the North american Datum of 1983 (NAD of 1983). 


\title{
Status of Water Levels and Selected Water-Quality Conditions in the Sparta-Memphis Aquifer in Arkansas and the Status of Water Levels in the Sparta Aquifer in Louisiana, Spring 2005
}

\author{
By T.P. Schrader and J.S. Jones
}

\section{Abstract}

The U.S. Geological Survey in cooperation with the Arkansas Natural Resources Commission, the Arkansas Geological Commission, and the Louisiana Department of Transportation and Development has monitored water levels in the Sparta Sand of Claiborne Group and Memphis Sand of Claiborne Group since the 1920's. Ground-water withdrawals have increased while water levels have declined since monitoring was initiated. This report has been produced to describe ground-water levels in the aquifers in the Sparta Sand and Memphis Sand and provide information for the management of this valuable resource.

The 2005 potentiometric-surface map of the aquifers in the Sparta Sand and Memphis Sand was constructed using water-level data collected in 333 wells in Arkansas and 120 wells in Louisiana during the spring of 2005. The highest water-level altitude measured in Arkansas was 327 feet above National Geodetic Vertical Datum of 1929 located in Grant County in the outcrop at the western boundary of the study area; the lowest water-level altitude was 189 feet below National Geodetic Vertical Datum of 1929 in Union County. The highest water-level altitude measured in Louisiana was 246 feet above National Geodetic Vertical Datum of 1929 located in Bossier Parish in the outcrop area near the western boundary of the study area; the lowest water-level altitude was 226 feet below National Geodetic Vertical Datum of 1929 in central Ouachita Parish.

Three large depressions centered in Columbia, Jefferson, and Union Counties in Arkansas are the result of large withdrawals for industrial and public supplies. In Louisiana, three major pumping centers are in Ouachita, Jackson, and Lincoln Parishes. Water withdrawals from these major pumping centers primarily is used for industrial and public-supply purposes. Withdrawals from Ouachita and Lincoln Parishes and Union County, Arkansas, primarily for industrial purposes, have caused the resulting cones of depression to coalesce so that the -40 foot potentiometric contour encircles the three pumping centers.
Seven smaller depressions are evident on the 2005 Sparta-Memphis potentiometric-surface map located in Webster and Winn Parishes, Louisiana, and Calhoun, Cleveland, western Columbia, Desha, and Lafayette Counties, Arkansas. The depression in Calhoun County initially was shown in the 1996-1997 potentiometric surface. The depression in Desha County initially was shown in the 1999 potentiometric surface. The depressions in Webster and Winn Parishes were shown as early as 1975. The depressions in Cleveland, western Columbia, and Lafayette Counties initially were shown in the 2003 potentiometric surface.

A map of differences in water-level measurements between 2001 and 2005 was constructed using the difference between water-level measurements from 294 wells in Arkansas and 29 wells in Louisiana. The difference in water levels between 2001 and 2005 ranged from -30.1 to 44.6 feet. The largest rise of 44.6 feet in water level measured was in Union County in Arkansas. The largest decline of 30.1 feet in water level measured was in Columbia County in Arkansas. Areas with a general rise in water levels in Arkansas are shown in Arkansas, Columbia, Craighead, Jefferson, Prairie, and the western half of Union Counties. The area around west-central Union County had rises as much as 44.6 feet, with seven wells showing a rise of 20 feet or greater, which is an annual rise of 5 feet or greater. Areas in Arkansas with a general decline in water level are shown in western Bradley, eastern Calhoun, Cleveland, Cross, Desha, Drew, Lafayette, Lee, Lincoln, Lonoke, Poinsett, and the eastern half of Union Counties.

In Louisiana, the water-level difference map showed a general rise in water levels in northern Claiborne, northern Webster, and northwestern Union Parishes mainly because of a decrease in industrial withdrawals in southern Arkansas, particularly Union County. Another rise in water level was indicated in western Jackson Parish where industrial withdrawals have been reduced. The remainder of the study area in Louisiana showed a general decline in water level ranging from -1.5 feet in Jackson Parish to -6.1 feet in Union Parish. 
Hydrographs were constructed for wells with a minimum of 25 years of water-level measurements. In Arkansas, the mean annual water-level rose only in Columbia, Lafayette, and Ouachita Counties. Mean annual declines occurred in Dallas, Grant, Phillips, Woodruff, Calhoun, Cleveland, Craighead, Cross, Desha, Drew, Jefferson, Lee, Union, Arkansas, Bradley, Lincoln, Lonoke, Poinsett, and Prairie Counties in Arkansas. In Louisiana, hydrographs were constructed using a minimum of 25 years of water-level measurements. At well Cl-149 in Claiborne Parish, a decline in water level is evident from 1981 until late 1999 at a rate of approximately -1.7 feet per year. Since 1999, a water-level increase of approximately 1.1 feet per year is evident at $\mathrm{Cl}-149$, mainly because of a reduction of industrial withdrawals in Union County, Arkansas.

Water samples were collected from 61 wells in the spring of 2005 and measured onsite for specific conductance and temperature in Arkansas. Specific conductance ranged from 32.7 microsiemens per centimeter in Ouachita County to 1,356 microsiemens per centimeter in Lee County. The median specific conductance was 278 microsiemens per centimeter and the mean specific conductance was 362 microsiemens per centimeter. Along the western border of the Sparta-Memphis aquifer in Arkansas near the outcrop area, ground water has low specific conductance-generally less than 200 microsiemens per centimeter. Specific conductance increases to the east and south. The statistical distribution of specific conductance values in 2005 has changed from the distribution of specific conductance values in 2003.

\section{Introduction}

The U.S. Geological Survey (USGS) in cooperation with the Arkansas Natural Resources Commission, the Arkansas Geological Commission, and the Louisiana Department of Transportation and Development has monitored water levels in the Sparta Sand of Claiborne Group and Memphis Sand of Claiborne Group (herein the geologic formations are referred to as the Sparta Sand and the Memphis Sand, respectively), since the 1920 's. Ground-water withdrawals have increased while water levels have declined since monitoring was initiated. This report describes results from two continuing projects that include the ground-water networks and basic data collection for Arkansas and Louisiana. The USGS has produced separate and combined reports, at various periodic schedules, discussing the groundwater conditions of the Sparta-Memphis aquifer in Arkansas and the Sparta aquifer in Louisiana. A combined report for Arkansas and Louisiana has been produced every 4 years since 1997 to describe ground-water levels in these aquifers and provide information for the management of this valuable resource.

This report presents a status of water levels in the SpartaMemphis aquifer in Arkansas and the Sparta aquifer in Louisiana, and water-quality conditions in the Sparta-Memphis aquifer in Arkansas. Herein, aquifers in the Sparta Sand and Memphis Sand will be referred to as the Sparta-Memphis aquifer throughout Arkansas and Louisiana. During the spring of 2005, 333 water levels in Arkansas and 120 water levels in Louisiana were measured in wells completed in the Sparta-Memphis aquifer. These measurements were used to provide information describing the potentiometric surface of the Sparta-Memphis aquifer. During the spring of 2005, 61 water-quality samples were collected and measured for temperature and specific conductance from wells completed in the Sparta-Memphis aquifer in Arkansas. Water-quality data were not measured for Louisiana. This report presents results as a potentiometric-surface map, a water-level difference map comparing water levels from 2001 to 2005, selected water-level hydrographs, a specific-conductance map for the Arkansas part of the aquifer, and water-level and water-quality data tables.

The study area (fig. 1) in Arkansas is bounded on the north by the Missouri State line, and on the east by the Tennessee and Mississippi State lines. The western boundary is defined as the western extent of the outcrop and subcrop (Hosman, 1982) of the Sparta Sand and the Memphis Sand. In Louisiana, the area is bounded on the south and east by the approximate downdip limit of freshwater (Payne, 1968) (plate 1) and the western boundary is defined by the western extent of the Sparta Sand aquifer. The Sparta Sand and the Memphis Sand occur in Arkansas and the Sparta Sand occurs in Louisiana. Water levels in the Sparta Sand aquifer generally correlate with those in the Memphis Sand aquifer; therefore, the water-bearing formations are considered to be one hydrologic unit (Stanton, 1997).

The authors acknowledge the contribution of data and the technical assistance of their staff, particularly Jeffrey A. Brantly and Ralf F. Montanus.

\section{Water Use}

Water use in the Sparta-Memphis aquifer in Arkansas generally has increased from 1980 to 2000 (fig. 2). In 1980 water use in the Sparta-Memphis aquifer in Arkansas was about 185 million gallons per day (Mgal/d) (Holland and Ludwig, 1981). There was a decline in water use to about $157 \mathrm{Mgal} / \mathrm{d}$ in 1985 (Holland, 1987). In 2000, water use in the Sparta-Memphis aquifer in Arkansas was about 287 $\mathrm{Mgal} / \mathrm{d}$ (Holland, 2004), an increase of 55 percent from 1980.

Water use from the Sparta-Memphis aquifer in Arkansas in 2000 was divided among three primary categories- irrigation, public supply, and industrial. Irrigation used about $175 \mathrm{Mgal} / \mathrm{d}$ (61 percent), public supply used about $55 \mathrm{Mgal} / \mathrm{d}$ (19 percent), and industrial used about $49 \mathrm{Mgal} / \mathrm{d}$ (17 percent). Agriculture and power generation accounted for about 1 percent each of the water use in the Sparta-Memphis aquifer in Arkansas in 2000. Major pumping centers that use the Sparta-Memphis aquifer for public supply and industry occur in Columbia, Jefferson, and Union Counties. Arkansas, Lonoke, Monroe, and Prairie 


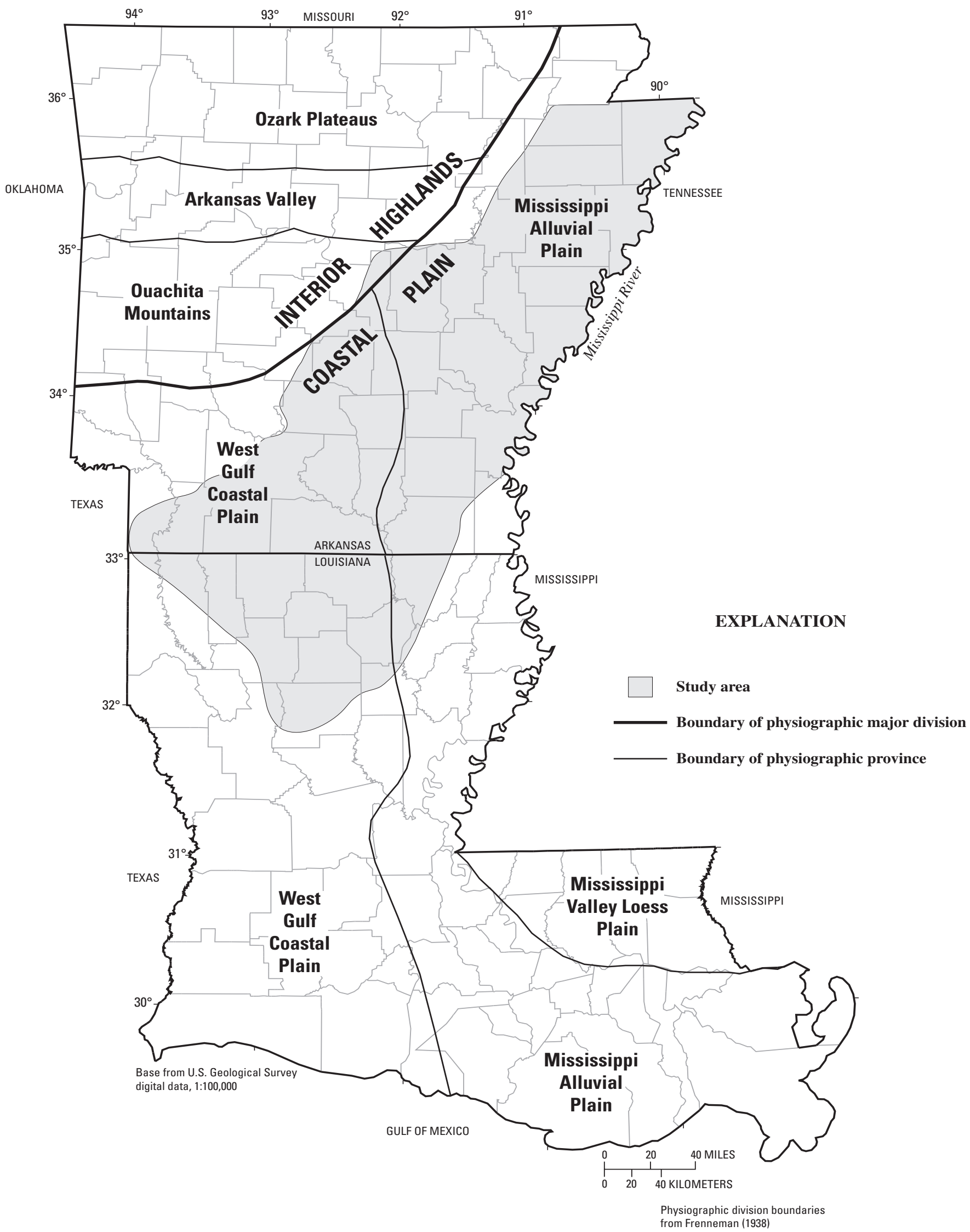

Figure 1. Location of study area. 
Counties accounted for the majority of the water withdrawn for irrigation from the Sparta-Memphis aquifer in 2000 (Holland, 2004).

Water use from the Sparta-Memphis aquifer in Louisiana was approximately $68 \mathrm{Mgal} / \mathrm{d}$ in 2000 (Sargent, 2002). Of that amount, approximately $38 \mathrm{Mgal} / \mathrm{d}$ (56 percent) was used for public supply, approximately $27 \mathrm{Mgal} / \mathrm{d}$ (40 percent) was used for industrial purposes, and the remaining $3 \mathrm{Mgal} / \mathrm{d}$ (4 percent) was used for rural domestic, livestock, irrigation, and aquaculture. Water use in the Sparta-Memphis aquifer in 2000 (68 $\mathrm{Mgal} / \mathrm{d}$ ) decreased approximately $3 \mathrm{Mgal} / \mathrm{d}$ (4 percent) from the amount used in 1995 (71 Mgal/d) (Lovelace and Johnson, 1996).

The Sparta-Memphis aquifer in Louisiana has three major pumping centers that accounted for more than 65 percent of the total withdrawals from the Sparta Sand aquifer in 2000 (Sargent, 2002). Major pumping centers are located in Ouachita, Bienville, and Lincoln Parishes. In 2000, Ouachita and Bienville Parishes used approximately 23.2 and $12.3 \mathrm{Mgal} / \mathrm{d}$, respectively, mainly for industrial purposes. Lincoln Parish used approximately 8.9 Mgal/d, mainly for public-supply purposes.

Total water use in the Sparta-Memphis aquifer in Arkansas and Louisiana generally increased from 1980 to 1995, then remained the same until 2000 (fig. 2). In 1980, total water use in Arkansas and Louisiana was about $251 \mathrm{Mgal} / \mathrm{d}$. In 1995 and 2000, total water use in Arkansas and Louisiana was about $355 \mathrm{Mgal} / \mathrm{d}$, an increase of 41 percent over the 1980 total water use.

\section{Well-Numbering System}

The well-numbering system used in this report is based upon the location of the wells according to the Federal land survey used in Arkansas. The component parts of a well number are the township designation; the range designation; the section number; three letter designation that indicates, respectively, the quarter section, the quarter-quarter section, and the quarter-quarter-quarter section in which the well is located; and the sequence number of the well in the quarter-quarterquarter section. The letters are assigned counterclockwise, beginning with " $\mathrm{A}$ " in the northeast quarter or quarter-quarter or quarter-quarter-quarter section in which the well is located. For example, well 01S03W04BBD16 (fig. 3) is located in Township 1 South, Range 3 West, in the southeast quarter of the northwest quarter of the northwest quarter of section 4 . This well is the 16th well in this quarter-quarter-quarter section of section 4 from which data were collected.

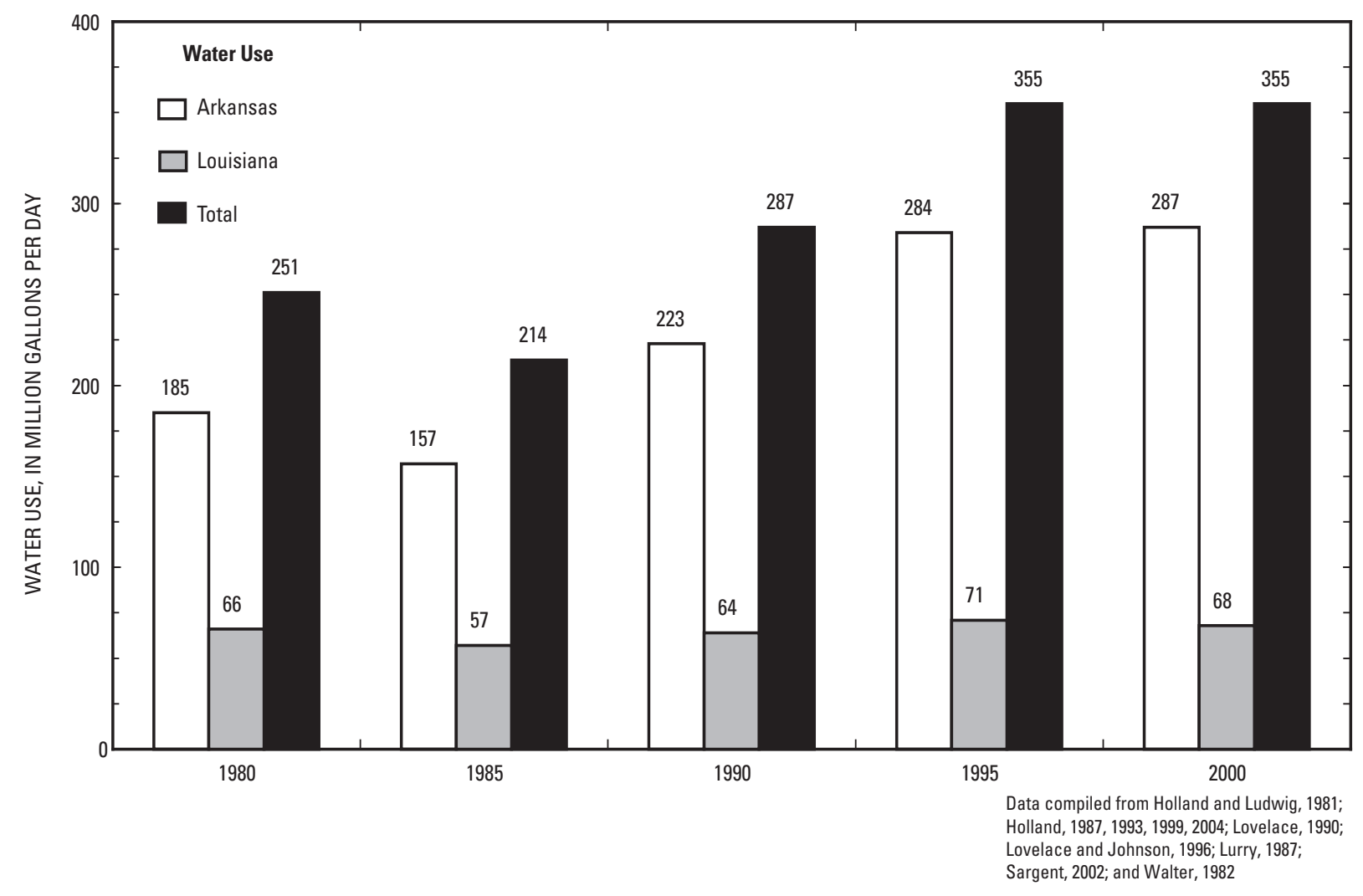

Figure 2. Water use in the Sparta-Memphis aquifer in Arkansas and Louisiana, 1980-2000. 


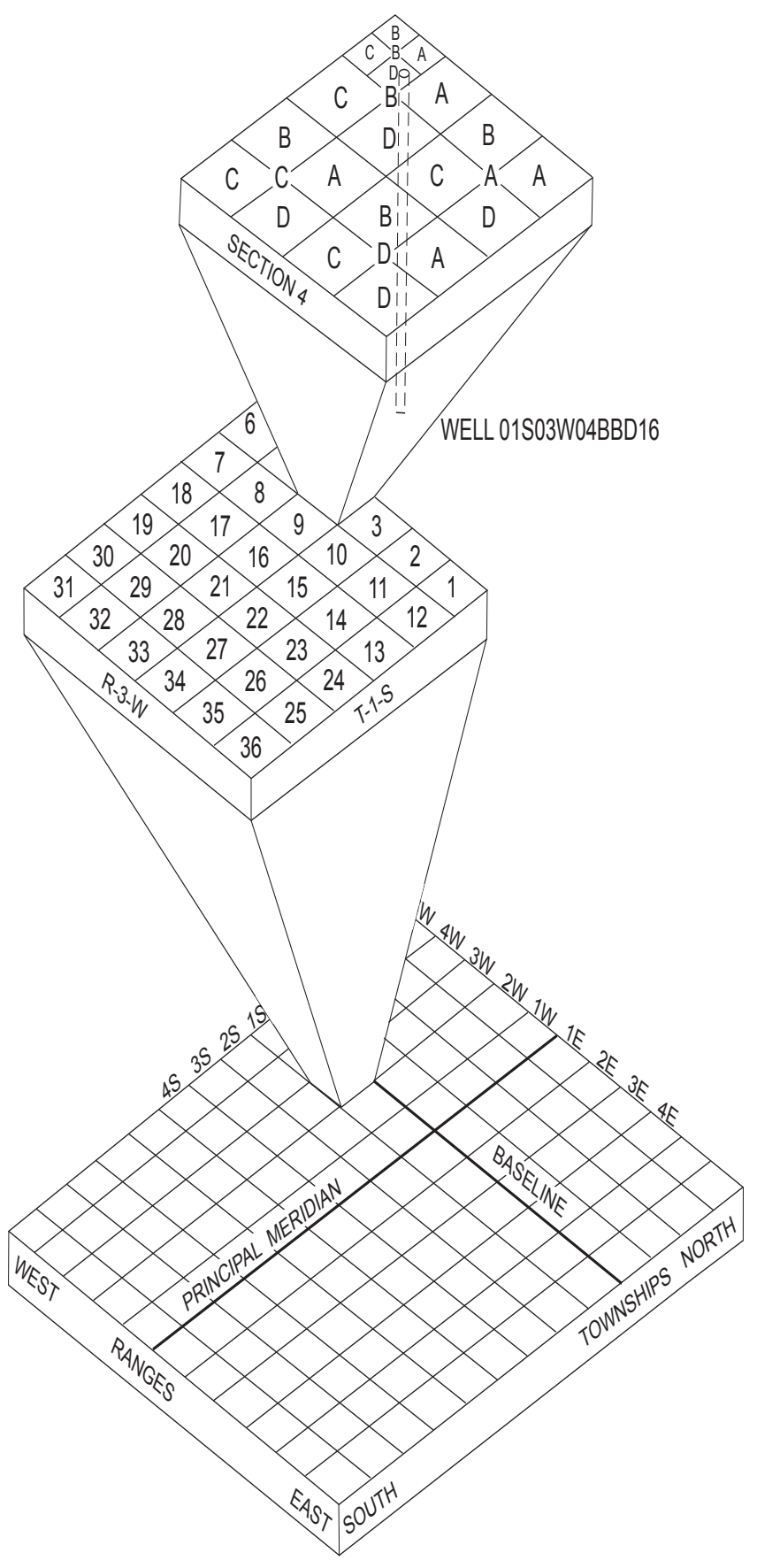

Figure 3. Well-numbering system.

In Louisiana, wells are identified by the Parish abbreviation followed by a sequence number based on the registration date of the well. For example, well Ou- 80 is identified by the Ouachita Parish abbreviation $(\mathrm{Ou})$, followed by a sequence number (80) corresponding to the date on which the well was registered with the State of Louisiana.

\section{Methods}

USGS personnel measured water levels from March 2005 to May 2005 from wells completed in the Sparta-Memphis aquifer. Measurements were made using steel or electric tapes graduated in hundredths of a foot. The steel and electric tapes were calibrated prior to collecting water-level measurements. Calibration was performed by comparing the steel or electric tapes to a standardized steel tape used only for calibration.

Wells locations were verified using Global Positioning System (GPS) receivers to acquire the horizontal coordinate information, latitude and longitude, based on the North American Datum of 1983. The latitude and longitude of the wells in Arkansas were recorded from a GPS accurate to one-tenth of a second of latitude and longitude (approximately 10-20 feet $(\mathrm{ft})$ ). The latitude and longitude of the well location were transferred to a topographic map and the altitude of the well (National Geodetic Vertical Datum of 1929) was determined from the topographic contours at the location on the map. Altitude is accurate to about one-half of the contour interval of the topographic map.

In Arkansas, water-quality samples were collected for specific-conductance analysis using the procedures described in the "National Field Manual for the Collection of WaterQuality Data" (U.S. Geological Survey, variously dated). Wells were purged a minimum of three-casing volumes. During the well purge, specific conductance and temperature were monitored until measurements stabilized. If the specific conductance and temperature were unstable, the well purge continued past the minimum three-casing volumes until specific-conductance and temperature values stabilized.

Specific-conductance data were measured from selected Arkansas wells using specific-conductance meters with temperature compensation. Specific-conductance meters were calibrated twice daily by comparing the measurement of the meter of two specific conductance calibration solutions. Specific conductance is a measure of the electrical conductance of a substance. As the dissolved-solids concentration in ground water increases, specific conductance increases. Specific-conductance data were not measured in Louisiana.

\section{Description of Aquifer}

The Sparta Sand and Memphis Sand (table 1) of Eocene age mainly consist of fine to medium sand. Some silt, clay, and lignite occur in the upper portion of the Sparta Sand and Memphis Sand. Sands in the Sparta Sand were deposited by shifting streams on a deltaic-fluvial flood plain (Payne, 1968). These sands mostly are interconnected, but separately identifiable sands can be traced for short distances (Snider and others, 1972). The Cook Mountain Formation of Claiborne Group overlies the Sparta Sand and serves as an upper confining unit (table 1). The permeable units of the Sparta Sand and the Memphis Sand compose the Sparta and Memphis aqui- 
6 Status of Water Levels and Selected Water-Quality Conditions in the Sparta-Memphis Aquifer in Arkansas and the Status of Water Levels in the Sparta Aquifer in Louisiana, Spring 2005

Table 1. Stratigraphic correlation of Louisiana and the north and south parts of Arkansas for the study area.

[Compiled from Petersen and others, 1985; Tomaszewski and others, 2002]

\begin{tabular}{|c|c|c|c|c|}
\hline Series & Group & Formations in Louisiana & $\begin{array}{l}\text { Formations in the } \\
\text { south part of Arkansas }\end{array}$ & $\begin{array}{l}\text { Formations in the } \\
\text { north part of Arkansas }\end{array}$ \\
\hline \multirow{7}{*}{ Eocene } & Jackson & Undifferentiated & Undifferentiated & Undifferentiated \\
\hline & \multirow{5}{*}{ Claiborne } & Cockfield Formation & Cockfield Formation & Cockfield Formation \\
\hline & & Cook Mountain Formation & Cook Mountain Formation & Cook Mountain Formation \\
\hline & & Sparta Sand & Sparta Sand & \multirow{3}{*}{ Memphis Sand } \\
\hline & & Cane River Formation & Cane River Formation & \\
\hline & & Carrizo Sand & Carrizo Sand & \\
\hline & \multirow{2}{*}{ Wilcox } & & Wilcox Group Undifferentiated & Wilcox Group Undifferentiated \\
\hline \multirow{2}{*}{ Paleocene } & & Wilcox Group Undifferentiated & & \\
\hline & Midway & Undifferentiated & Undifferentiated & Undifferentiated \\
\hline
\end{tabular}

fers. The Sparta-Memphis aquifer occurs in Arkansas and the Sparta aquifer occurs in Louisiana. In this report, the aquifers are referred to as the Sparta-Memphis aquifers throughout the study area.

The Sparta Sand is composed of a sequence of alternating sand and clay beds between the massive clays of the overlying Cook Mountain Formation of Claiborne Group and the underlying Cane River Formation of Claiborne Group confining units (Hosman and others, 1968) shown in table 1. The Sparta Sand is in the southern part of the study area (south of about 35 degrees latitude, plate 1) where the Cane River Formation of Claiborne Group is composed predominantly of clay. The Memphis Sand is in the northern part of the study area (north of about 35 degrees latitude), and the Cane River Formation of Claiborne Group or equivalent facies is composed predominantly of sand. In the southern area, the Claiborne Group is subdivided into the Carrizo Sand, Cane River Formation, Sparta Sand, Cook Mountain Formation, and the Cockfield Formation (table 1). The equivalent section in the northern area is subdivided into the Memphis Sand, the Cook Mountain Formation, and the Cockfield Formation. The Memphis Sand in the northern area is equivalent to the Carrizo Sand, the Cane River Formation, and the Sparta Sand in the southern area. The Memphis Sand is underlain by a thick layer of clay in the upper part of the Wilcox Group (Hosman and others, 1968).

The Sparta Sand generally thickens and ground water increases in salinity as depth of occurrence increases to the southeast. The Sparta Sand is 50 to $200 \mathrm{ft}$ thick within the outcrop area (along the western limit) and thickens easterly to nearly $900 \mathrm{ft}$. The Sparta Sand contains freshwater throughout most of its extent in Arkansas. However, saltwater is present in the extreme southeastern part of the State in parts of Ashley, Chicot, and Union Counties (Payne, 1968).

In Louisiana, the Sparta Sand generally dips to the east and southeast. Near the Sabine uplift in northwestern Louisiana (plate 1), the dip in northwestern Louisiana is northeasterly. The Sparta Sand is approximately 50 to $300 \mathrm{ft}$ thick within the outcrop area and thickens easterly to nearly $700 \mathrm{ft}$ near the downdip limit of freshwater. The approximate downdip limit of freshwater is shown on plate 1. Downdip from the limit of freshwater, most or all sands in the Sparta Sand aquifer contain saltwater; updip from the freshwater limit, sands in the upper part of the aquifer contain freshwater but some sands in the lower part of the aquifer contain saltwater. A more detailed description of the Sparta-Memphis aquifer (upon which the preceding descriptions are based) is provided by Edds and Fitzpatrick (1989), Hosman and others (1968), Payne (1968), Petersen and others (1985), and Ryals (1980).

\section{Water Levels}

Water-level measurements collected in wells screened in the Sparta-Memphis aquifer (appendix 1) were used to produce a regional potentiometric-surface map (plate 1). Water levels measured during the spring of 2005 were subtracted from water levels measured during the spring of 2001 at selected Sparta-Memphis aquifer wells (appendix 2) and were used to create a water-level difference map (plate 2). Data from wells that have water-level measurements with a minimum 25-year period of record were used to produce hydrographs shown in figure 4 and compiled by county for 
Arkansas. The water levels shown in the hydrographs indicate long-term changes in hydrologic conditions. Long-term waterlevel declines shown in the hydrographs reflect the development of the depressions on the potentiometric surface.

\section{Potentiometric-Surface Map}

A potentiometric-surface map was constructed using 453 water-level measurements from wells completed in the SpartaMemphis aquifer. Hydrologic principles, water-use data, and historical information are interpreted with the water-level data to delineate the potentiometric-surface contours. The number and location of wells used to construct potentiometric-surface maps differ from year to year. The combined information will result in both variations and similarities in potentiometric contours that define the surface depicted on the maps produced in different years.

The 2005 potentiometric-surface map of the Sparta-Memphis aquifer shows the altitude to which water would have stood in tightly cased wells completed in the aquifer (plate 1). The map is based upon water-level data collected in 333 wells in Arkansas and 120 wells in Louisiana (appendix 1), in the Sparta-Memphis aquifer during the spring of 2005. The surface is mapped by determining the altitude of the water levels measured in the wells and is represented on the map by contours that connect points of equal water-level altitude. The general direction of ground-water flow in the Sparta-Memphis aquifer is perpendicular to the contours in the direction of decreasing hydraulic gradient.

Cones of depression or potentiometric depressions, shaded in gray on plate 1, in Jefferson and Union Counties in Arkansas and Ouachita Parish in Louisiana, usually are caused by withdrawal rates that exceed the recharge rates within the aquifer over an extended period of time. When a well is pumped, the water level in and around the well declines, creating a slope or gradient on the potentiometric surface. The gradient increases the flow of water in the aquifer towards the lower water level. When pumping stops the water level recovers. In an area where withdrawal rates exceed the recharge rates in the aquifer, the area of the declining water level expands to form a cone of depression or potentiometric-surface depression. The depression can reach equilibrium when the flow rate increases with the expanding depression or the withdrawal rate decreases with the declining water level.

The natural direction of flow, which historically was eastward from the western limit and then southward, in the Sparta-Memphis aquifer is altered in areas by large groundwater withdrawals. The regional direction of ground-water flow in the Sparta-Memphis aquifer is generally to the southsoutheast in the northern half of Arkansas and to the east and south in the southern half of Arkansas and Louisiana, away from the outcrop area except where affected by large groundwater withdrawals (Joseph, 1997, 2000). The highest waterlevel altitude measured in Arkansas was $327 \mathrm{ft}$ above NGVD of 1929, located in Grant County in the outcrop at the western boundary of the study area; the lowest water-level altitude was $189 \mathrm{ft}$ below NGVD of 1929 in Union County (appendix 1). The water level at this well in Union County was $10 \mathrm{ft}$ higher than in 2003 (Schrader, 2006). The highest water-level altitude measured in Louisiana was $246 \mathrm{ft}$ above NGVD of 1929, located in Bossier Parish in the outcrop area near the western boundary of the study area; the lowest water-level altitude was 226 ft below NGVD of 1929 in central Ouachita Parish.

Three large depressions are shown in Arkansas on the 2005 potentiometric-surface map, centered in Columbia, Jefferson, and Union Counties, as a result of large withdrawals for industrial and public supplies (Holland, 2004, 1999, 1993). The depression centered in Jefferson County deepened and expanded in recent years into Prairie County where withdrawals for agricultural, irrigation, and public supplies have increased from 22.6 Mgal/d in 1990 to $24.7 \mathrm{Mgal} / \mathrm{d}$ in 1995 to $27.7 \mathrm{Mgal} / \mathrm{d}$ in 2000 (Holland, 2004, 1999, 1993). This depression has approximately the same shape and depth as on the 2003 potentiometric-surface map (Schrader, 2006). The depressions in Columbia and Union Counties are elongated east to west because of large industrial withdrawals and coalesce at or near the Columbia and Union County line. The deepest measurement during 2005 in the center of the depression in Union County has risen by 10 feet since 2003. The area enclosed by the deepest contour, $180 \mathrm{ft}$ below NGVD of 1929 , is about one-third the area enclosed in the same contour in the 2001 potentiometric-surface map (Schrader, 2004). The depression in Union County has receded from Union Parish, Louisiana. The -100-ft contour had extended into Union Parish on the 2001 potentiometric-surface map (Schrader, 2004). The -60-ft contour on the 2005 potentiometric-surface map is near the Arkansas-Louisiana State border. The deepest water-level measurement in the depression in Columbia County was about $13 \mathrm{ft}, 7 \mathrm{ft}$, and $10 \mathrm{ft}$ below NGVD of 1929 in 2001, 2003, and 2005 , respectively. This depression is similar in shape and depth as on the 2003 potentiometric-surface map. The fluctuations of a few feet in the deepest water-level measurement may be the result of variations in climate or variability in the location of withdrawals. The similarity of the shape and size with the 2003 potentiometric-surface map may suggest that this depression may be stabilizing in this configuration. Continued monitoring of the water level in this area will determine if this depression has stabilized, expanded, or declined in shape and depth.

A broad depression in western Poinsett and Cross Counties in Arkansas was first shown in the 1995 potentiometricsurface map (Stanton, 1997) and has been variable in size since 1995. The depression expanded in area in 1997 and 1999, then decreased in area in 2003 and 2005. In 1995, this depression was enclosed within the 150 -foot contour in the southwestern corner of Poinsett County. In 1997, the depression covered most of the western half of Poinsett County (Joseph, 1997). In 1999 and 2001, the depression extended from Poinsett County through Cross County into St. Francis County (Joseph, 2000; Schrader, 2004). In 2003, the depression covered most of the western half of Poinsett County 
(Schrader, 2006). In the 2005 potentiometric-surface map, the depression covers part of western Poinsett County and extends into northwestern Cross County. In 2001, the mapped contour interval was changed from $25-\mathrm{ft}$ to 20 -ft intervals, and the 20 -ft interval has been used for potentiometric-surface maps since 2001. The 1999 and 2001 potentiometric maps indicate that this depression is similar in size and extent. This would suggest that the variability in size from 1995 to 2005 may not be because of the change in contour interval.

In Louisiana, three major pumping centers are shown on the 2005 potentiometric map in Ouachita, Jackson, and Lincoln Parishes. Water usage from these major pumping centers primarily is used for public and industrial supply purposes (Sargent, 2002). Withdrawals from Ouachita and Lincoln Parishes in Louisiana and Union County in Arkansas, used primarily for public supply and industrial purposes, have caused the resulting cones of depression to coalesce into the $-40 \mathrm{ft}$ potentiometric contour that encircles the three pumping centers.

Seven smaller depressions are evident on the 2005 Sparta-Memphis potentiometric-surface map located in Webster and Winn Parishes, Louisiana, and Calhoun, Cleveland, western Columbia, Desha, and Lafayette Counties, Arkansas. The depressions in Webster and Winn Parishes were evident on the 2001 potentiometric-surface map and were shown as early as 1975 (Ryals, 1980). These two depressions have increased in depth from 2001 to 2005. Two depressions in Calhoun and western Lincoln Counties in Arkansas were evident on the 2001 potentiometric-surface map (Schrader, 2004). The depression in Calhoun County appears to be stable since 2001 with similar shape and depth. This depression initially was shown on the 1996-1997 potentiometric-surface map (Joseph, 1997). The depression in western Lincoln County has merged with the large depression in Jefferson County on the 2005 potentiometric-surface map. The water level in the depression in Cleveland County has declined in well 09S11W01DCA1 from $24 \mathrm{ft}$ above NGVD of 1929 to $18 \mathrm{ft}$ above NGVD of 1929 since 2003, when this depression was initially shown in the potentiometric surface (Schrader, 2004). The water level in the depression in Desha County, at well 12S03W26CBB1, has declined from $61 \mathrm{ft}$ above NGVD of 1929 in 1999 to $48 \mathrm{ft}$ above NGVD of 1929 in 2005. This depression was connected to the cone of depression centered in Jefferson County in 2001, and initially was shown on the 1999 potentiometric-surface map (Joseph, 2000). Rising water levels in eastern Drew County separated the cone in Desha County from the larger cone centered in Jefferson County. In western Columbia and Lafayette Counties, the area and depth of the depressions are similar in 2003 and 2005. The depressions in western Columbia and Lafayette Counties were not shown on potentiometric surfaces prior to 2003.

Short-term variations in climate and withdrawals may account for these smaller depressions. Local increases in water withdrawals may result in the formation of long-term cones of depression. Continued monitoring of the Sparta-Memphis aquifer potentiometric surface could determine if these depressions are related to climate variations or withdrawals.

The potentiometric surface indicates that large withdrawals have altered or reversed the natural direction of flow in most areas. Flow in the areas surrounding the depression is toward the depression near the center of pumping. In the northern third of the study area, flow is from the east, west, and north towards the depression in Poinsett County. In the central third of the study area, flow is dominated by the depression centered in Jefferson County. Flow from all directions is towards the depression in Jefferson County, with the exception of Cleveland County. In Cleveland County the flow is primarily towards the southeast and northeast to the small depression centered in Cleveland County. In the southern third of the study area, flow is dominated by the three depressions in Union and Columbia Counties, Arkansas, and Ouachita Parish, Louisiana. Flow is radially towards the center of the depressions. In most of eastern Columbia County, flow is west towards the depression in the center of Columbia County. Near the Columbia-Union County line, flow reverses direction east towards the depression in Union County. In Ashley and Chicot Counties, flow is south-southwest. In Louisiana, flow generally is southeast from areas of recharge to areas of discharge, but is influenced by withdrawals from pumping centers in Union, Webster, Ouachita, Lincoln, Jackson, and Winn Parishes.

\section{Water-Level Difference Map from 2001 to 2005}

A water-level difference map (plate 2) was constructed using the difference between water-level measurements made during 2001 and 2005 from 294 wells in Arkansas and 29 wells in Louisiana (appendix 2). The difference in water level was calculated by subtracting the 2005 depth-to-water level from the 2001 depth-to-water level. Positive values indicate a rise and negative values indicate a decline in water level. Rises in the water level are indicated on plate 2 with blue triangles pointing upward; declines in the water level are indicated with red triangles pointing downward. Triangles are scaled to the relative value of the rise or decline. Water-level differences do not necessarily equate to a water-level trend, but are intended to show where water levels have increased or decreased from 2001 to 2005.

The difference in water level between 2001 and 2005 ranged from -30.1 to $44.6 \mathrm{ft}$. The largest rise ( $44.6 \mathrm{ft}$ ) in water level measured was in Union County in Arkansas. The largest decline (30.1 ft) in water level measured was in Columbia County in Arkansas. Between 1999 and 2003, a large public supply converted from a primary source of ground water to a primary source of surface water (Terrance W. Holland, U.S. Geological Survey, written commun., 2005). Withdrawals from the Sparta-Memphis aquifer in Columbia County decreased from about $29.1 \mathrm{Mgal} / \mathrm{d}$ in 1996 to $2.6 \mathrm{Mgal} / \mathrm{d}$ in 2000 and $1.2 \mathrm{Mgal} / \mathrm{d}$ in 2003. Withdrawals from the wells around the largest rise decreased from about $1.02 \mathrm{Mgal} / \mathrm{d}$ in 
1996 to $0.03 \mathrm{Mgal} / \mathrm{d}$ in 2000 and $0.04 \mathrm{Mgal} / \mathrm{d}$ in 2003. The decrease in withdrawals resulted in the large rises in Columbia County. When public supply changed to surface water as the primary source, an industrial user decreased the amount of public-supplied water and increased self-supplied ground water. The well near the largest decline withdrew about 0.00 $\mathrm{Mgal} / \mathrm{d}$ in 1996, $0.11 \mathrm{Mgal} / \mathrm{d}$ in 2000, and $0.10 \mathrm{Mgal} / \mathrm{d}$ in 2003 (Terrance W. Holland, U.S. Geological Survey, written commun., 2006); the increase in self-supplied ground water may have contributed to the largest decline in water level.

Areas with a general rise in water levels in Arkansas are shown in Arkansas, Columbia, Craighead, Jefferson, Prairie Counties and the western half of Union County (plate 2). The inset area on plate 2 indicates an expanded view of part of Union County. In the area around west-central Union County (plate 2) water levels rose as much as $44.6 \mathrm{ft}$, with seven wells rising $20 \mathrm{ft}$ or greater, which is an average annual rise of $5 \mathrm{ft}$ or greater. The rising water level around west-central Union County coincides with water conservation measures initiated in 1999 and the conversion of large industrial ground-water users to surface water from the Ouachita River in December, 2004 (Robert Reynolds, Union County Water Conservation Board, written commun., 2006). The area in Arkansas, Jefferson, Lonoke, and Prairie Counties indicates mostly rising water levels, the largest rise is $35.7 \mathrm{ft}$, with seven wells rising $20 \mathrm{ft}$ or greater.

Areas in Arkansas with a general decline in water level are shown in western Bradley, eastern Calhoun, Cleveland, Cross, Desha, Drew, Lafayette, Lee, Lincoln, Lonoke, and Poinsett Counties; also the eastern half of Union County. Water levels in Lonoke County declined about -0.8 to $-7.9 \mathrm{ft}$. The single large rise of $30.4 \mathrm{ft}$ in Lonoke County was measured in a well with an inoperable pump and water was not withdrawn for several months in 2005. The area of western Bradley, eastern Calhoun, Cleveland, Desha, Drew, and Lincoln Counties indicate areas of mostly declines of less than 4.5 $\mathrm{ft}$, with five large declines of 8.7, 9.6, 10.4, 10.7, and $12.0 \mathrm{ft}$. The area of Cross and Poinsett Counties are mostly declines of $4.0 \mathrm{ft}$ or less, with the largest decline of $5.8 \mathrm{ft}$. Lafayette County declined about $3.1 \mathrm{ft}$ or less. The eastern half of Union County declined in two wells 17.7 and $11.7 \mathrm{ft}$, with most of the declines being $5.2 \mathrm{ft}$ or less. Lee County has declines from 3.6 to $8.4 \mathrm{ft}$.

In Louisiana, the water-level difference map (plate 2) indicated a general rise in water levels in northern Claiborne, northern Webster, and northwestern Union Parishes mainly because of a decrease in industrial ground-water withdrawals in southern Arkansas, particularly Union County. A rise in water level was indicated in western Jackson Parish where industrial withdrawals have been reduced. Rising water levels ranged from $0.6 \mathrm{ft}$ in Claiborne Parish at well C1-116 to 10.3 $\mathrm{ft}$ in Jackson Parish at well Ja-49. The remainder of the study area in Louisiana indicated a general decline in water levels ranging from $1.5 \mathrm{ft}$ in Jackson Parish at well Ja-148 to $6.1 \mathrm{ft}$ in Union Parish at well Un-134.

\section{Long-Term Hydrographs}

Hydrographs were constructed for wells with a minimum of 25 years of water-level measurements. Selected hydrographs are shown in figure 4 with locations indicated on plate 1. The minimum 25-year period of record is used to evaluate long-term trends not dominated by variations in climate and localized pumping rates on water levels in a single well. A trend line using linear regression was calculated for the period from 1981 to 2005 to determine the slope in feet per year (ft/yr) for water levels in each well. The slope of the trend line represents the typical annual decline or rise in water level during the 25-year period. A statistical summary of the number of wells, the range of the annual rise or decline in water level for the county, the mean, and the median value for each county in Arkansas are listed in table 2. Negative values denote a decline in water level. Statistical hydrograph data were not compiled in table 2 by parish for Louisiana.

In Arkansas, during the period 1981-2005, the county mean annual water-level rose only in Columbia, Lafayette and Ouachita Counties. Mean annual declines were between $0.5 \mathrm{ft} /$ yr and $0.0 \mathrm{ft} / \mathrm{yr}$ in Dallas, Grant, Phillips, and Woodruff Counties. Mean annual declines were between $1.0 \mathrm{ft} / \mathrm{yr}$ and $0.5 \mathrm{ft} / \mathrm{yr}$ in Calhoun, Cleveland, Craighead, Cross, Desha, Drew, Jefferson, Lee, and Union Counties. Mean annual declines were between $1.5 \mathrm{ft} / \mathrm{yr}$ and $1.0 \mathrm{ft} / \mathrm{yr}$ in Arkansas, Bradley, Lincoln, Lonoke, Poinsett, and Prairie Counties.

In Louisiana, declines in the Sparta-Memphis aquifer generally are shown at wells Cl-149 (hydrograph LB, fig. 4, plate 1), in Claiborne Parish, L-26 (hydrograph LD, fig. 4, plate 1), in Lincoln Parish, Un-26 (hydrograph LF, fig. 4, plate 1), in Union Parish, W-172 (hydrograph LH, fig. 4, plate 1), in Winn Parish, Ou-444 (hydrograph LE, fig. 4, plate 1) in Ouachita Parish, Ja-147 (hydrograph LC, fig. 4, plate 1), in Jackson Parish, and Bi-144 (hydrograph LA, fig. 4, plate 1) in Bienville Parish for the period of record from 1981-2005. The only exception is at well Cl-149, where the water level indicates an increase beginning in late 1999 and continues to the present. From 1981 to late 1999, Cl-149 indicates a declining water level at the rate of approximately $1.7 \mathrm{ft} / \mathrm{yr}$ and after 1999, an increase in water level at a rate of approximately 1.1 $\mathrm{ft} / \mathrm{yr}$. The rising water level in this well is likely a result of decreased industrial withdrawals in Union County, Arkansas. 
10 Status of Water Levels and Selected Water-Quality Conditions in the Sparta-Memphis Aquifer in Arkansas and the Status of Water Levels in the Sparta Aquifer in Louisiana, Spring 2005

Table 2. Statistical summary of annual rise-decline in water level by county for wells in the Sparta-Memphis aquifer in Arkansas, 1981-2005.

[Annual rise or decline in water level for each well is calculated using linear regression. Negative values represent a decline in water level]

\begin{tabular}{|c|c|c|c|c|}
\hline County & $\begin{array}{l}\text { Number } \\
\text { of wells }\end{array}$ & $\begin{array}{c}\text { Range or value } \\
\text { of average } \\
\text { rise/decline } \\
\text { in water level } \\
\text { (feet/year) }\end{array}$ & $\begin{array}{c}\text { Mean } \\
\text { annual } \\
\text { rise/decline } \\
\text { in water level } \\
\text { (feet/year) }\end{array}$ & $\begin{array}{c}\text { Median } \\
\text { annual } \\
\text { rise/decline } \\
\text { in water level } \\
\text { (feet/year) }\end{array}$ \\
\hline Arkansas & 23 & -2.56 to -0.07 & -1.21 & -1.28 \\
\hline Bradley & 3 & -1.39 to -0.73 & -1.06 & -1.06 \\
\hline Calhoun & 2 & -0.95 to -0.62 & -0.78 & -0.78 \\
\hline Cleveland & 4 & -1.75 to -0.55 & -0.97 & -0.78 \\
\hline Columbia & 10 & -0.84 to +2.05 & +0.14 & -0.05 \\
\hline Craighead & 2 & -0.88 to -0.73 & -0.80 & -0.80 \\
\hline Cross & 4 & -1.24 to -0.51 & -0.89 & -0.91 \\
\hline Dallas & 5 & -0.55 to +0.04 & -0.26 & -0.18 \\
\hline Desha & 5 & -1.57 to -0.66 & -0.93 & -0.84 \\
\hline Drew & 5 & -0.95 to -0.18 & -0.61 & -0.51 \\
\hline Grant & 7 & -1.39 to -0.11 & -0.41 & -0.20 \\
\hline Jefferson & 14 & -1.64 to -0.51 & -0.98 & -0.99 \\
\hline Lafayette & 2 & +0.04 to +0.26 & +0.15 & +0.15 \\
\hline Lee $^{1}$ & 1 & -0.55 & -0.55 & -0.55 \\
\hline Lincoln & 5 & -2.04 to -0.84 & -1.37 & -1.35 \\
\hline Lonoke $^{1}$ & 1 & -1.13 & -1.13 & -1.13 \\
\hline Ouachita & 6 & -0.07 to +0.91 & +0.18 & +0.02 \\
\hline Phillips & 6 & -0.69 to +0.66 & -0.11 & -0.27 \\
\hline Poinsett & 2 & -1.24 to -1.22 & -1.23 & -1.23 \\
\hline Prairie & 8 & -1.53 to -0.58 & -1.15 & -1.20 \\
\hline Union & 27 & -2.26 to -0.11 & -0.97 & -0.84 \\
\hline Woodruff ${ }^{1}$ & 1 & 0.00 & 0.00 & 0.00 \\
\hline
\end{tabular}

\footnotetext{
${ }^{1}$ This county contained one well with a hydrograph of 25 years or more.
} 


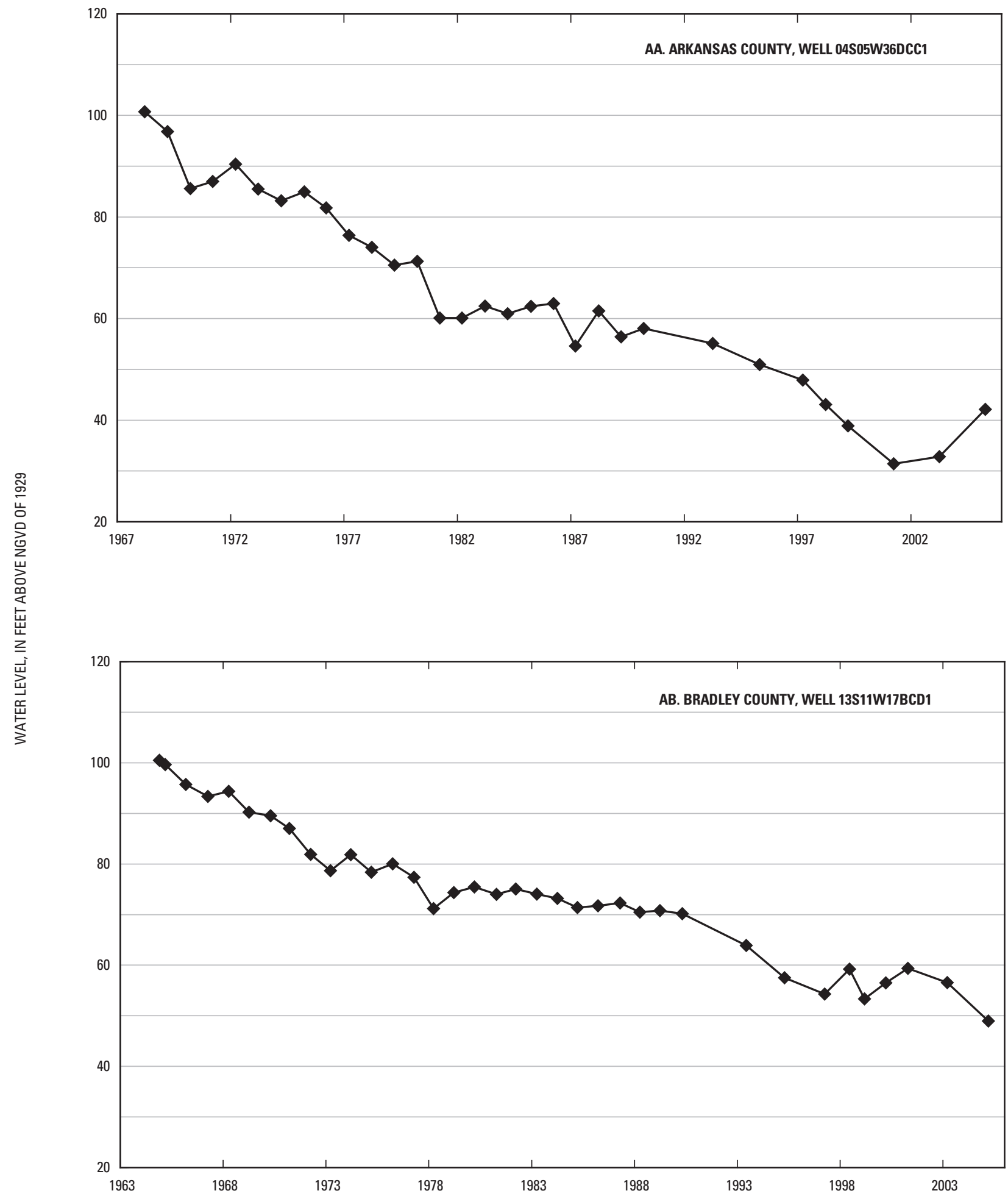

Figure 4. Water-level hydrographs for selected wells completed in the Sparta-Memphis aquifer in Arkansas and Louisiana. Well location listed in appendix 1. 
12 Status of Water Levels and Selected Water-Quality Conditions in the Sparta-Memphis Aquifer in Arkansas and the Status of Water Levels in the Sparta Aquifer in Louisiana, Spring 2005
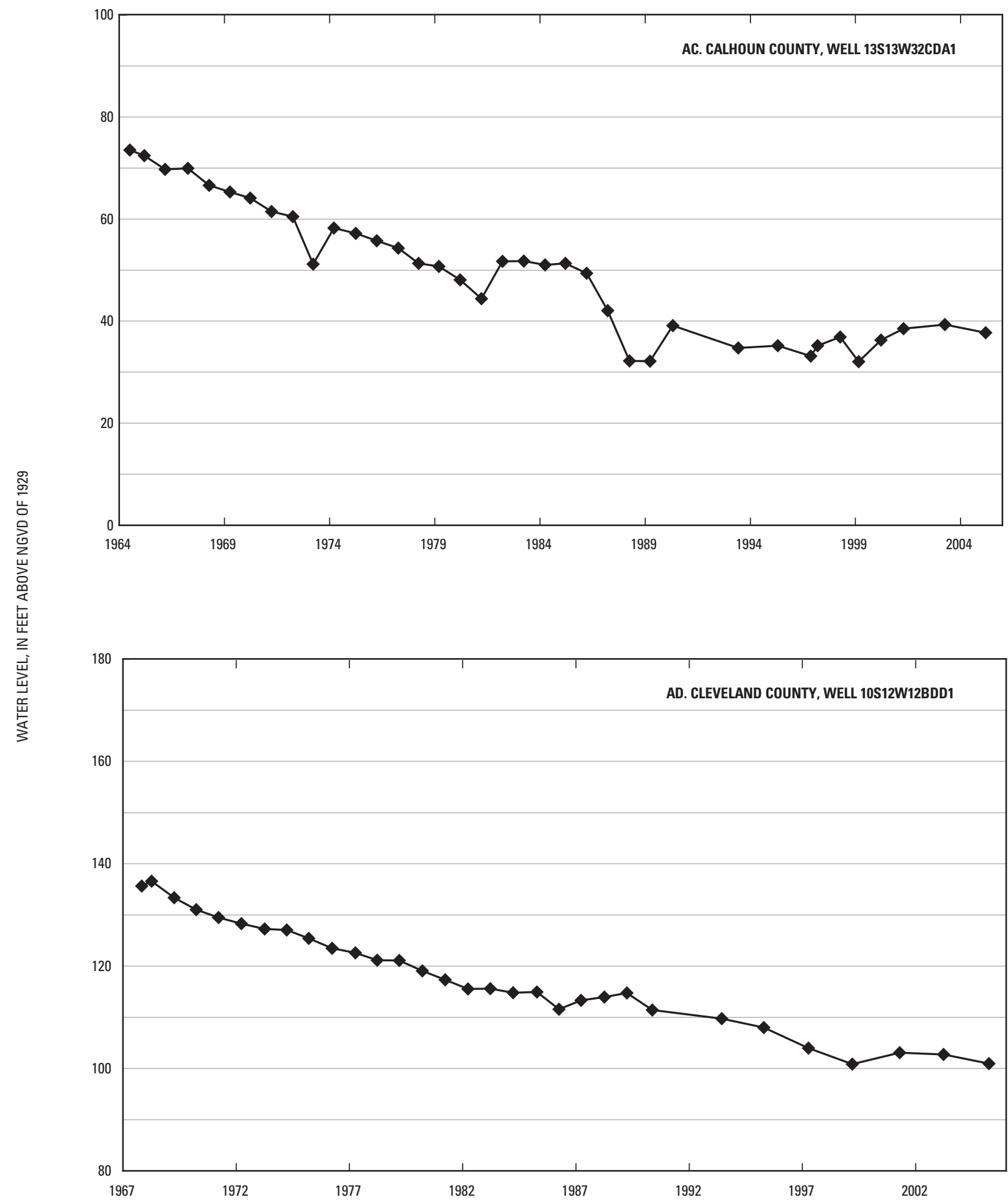

Figure 4. Water-level hydrographs for selected wells completed in the Sparta-Memphis aquifer in Arkansas and Louisiana. Well location listed in appendix 1.-Continued 


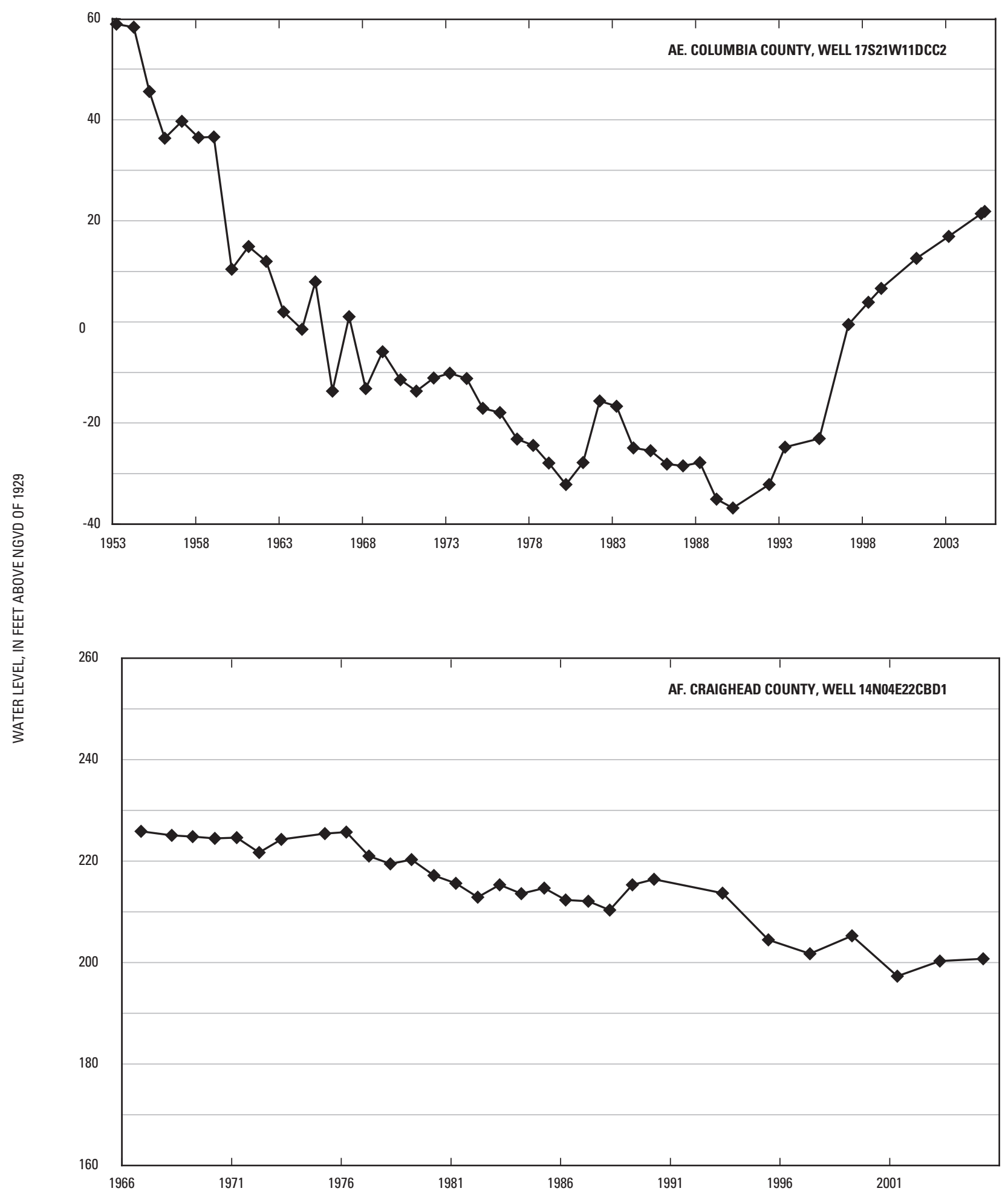

Figure 4. Water-level hydrographs for selected wells completed in the Sparta-Memphis aquifer in Arkansas and Louisiana. Well location listed in appendix 1.-Continued 
14 Status of Water Levels and Selected Water-Quality Conditions in the Sparta-Memphis Aquifer in Arkansas and the Status of Water Levels in the Sparta Aquifer in Louisiana, Spring 2005

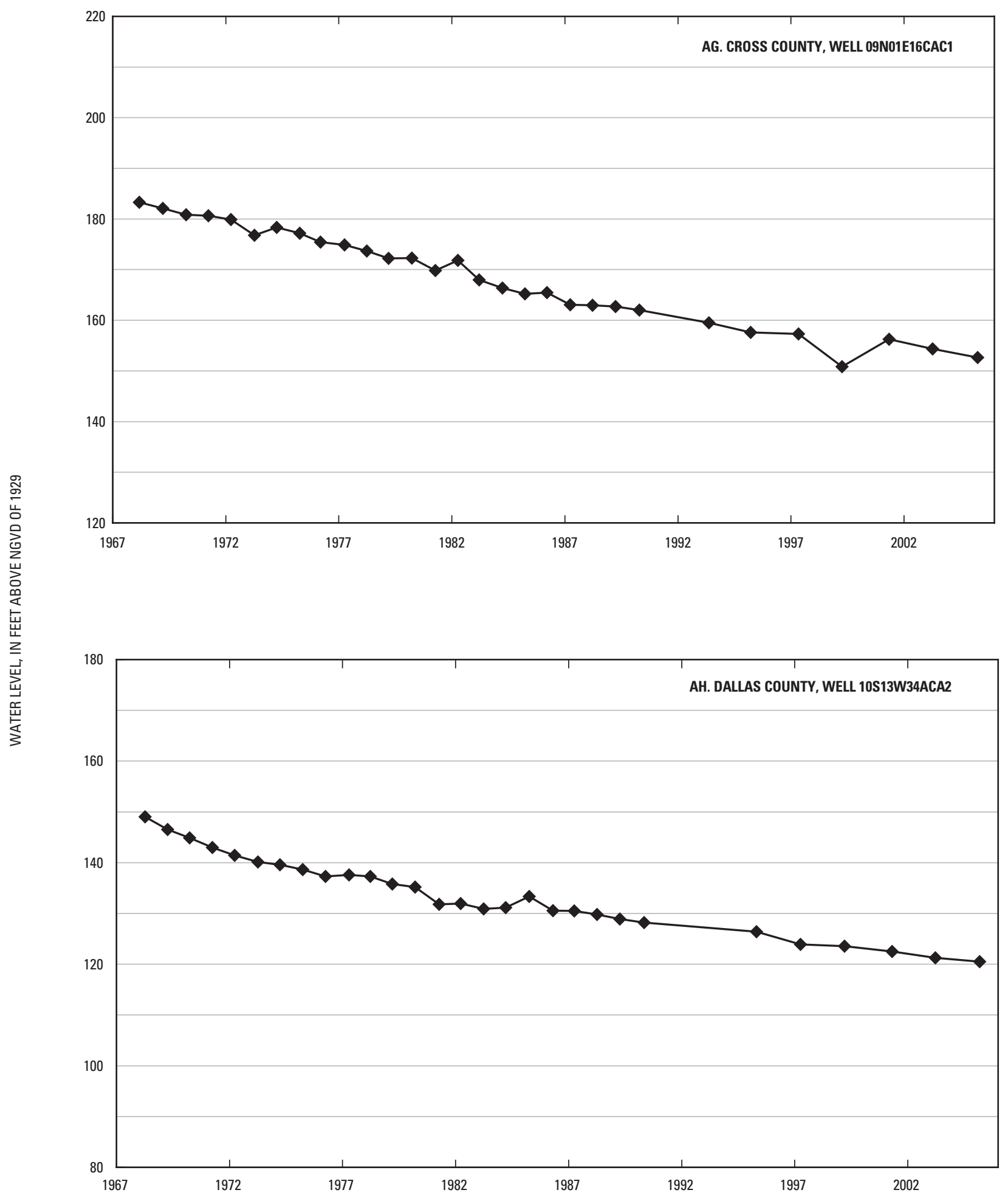

Figure 4. Water-level hydrographs for selected wells completed in the Sparta-Memphis aquifer in Arkansas and Louisiana. Well location listed in appendix 1.-Continued 


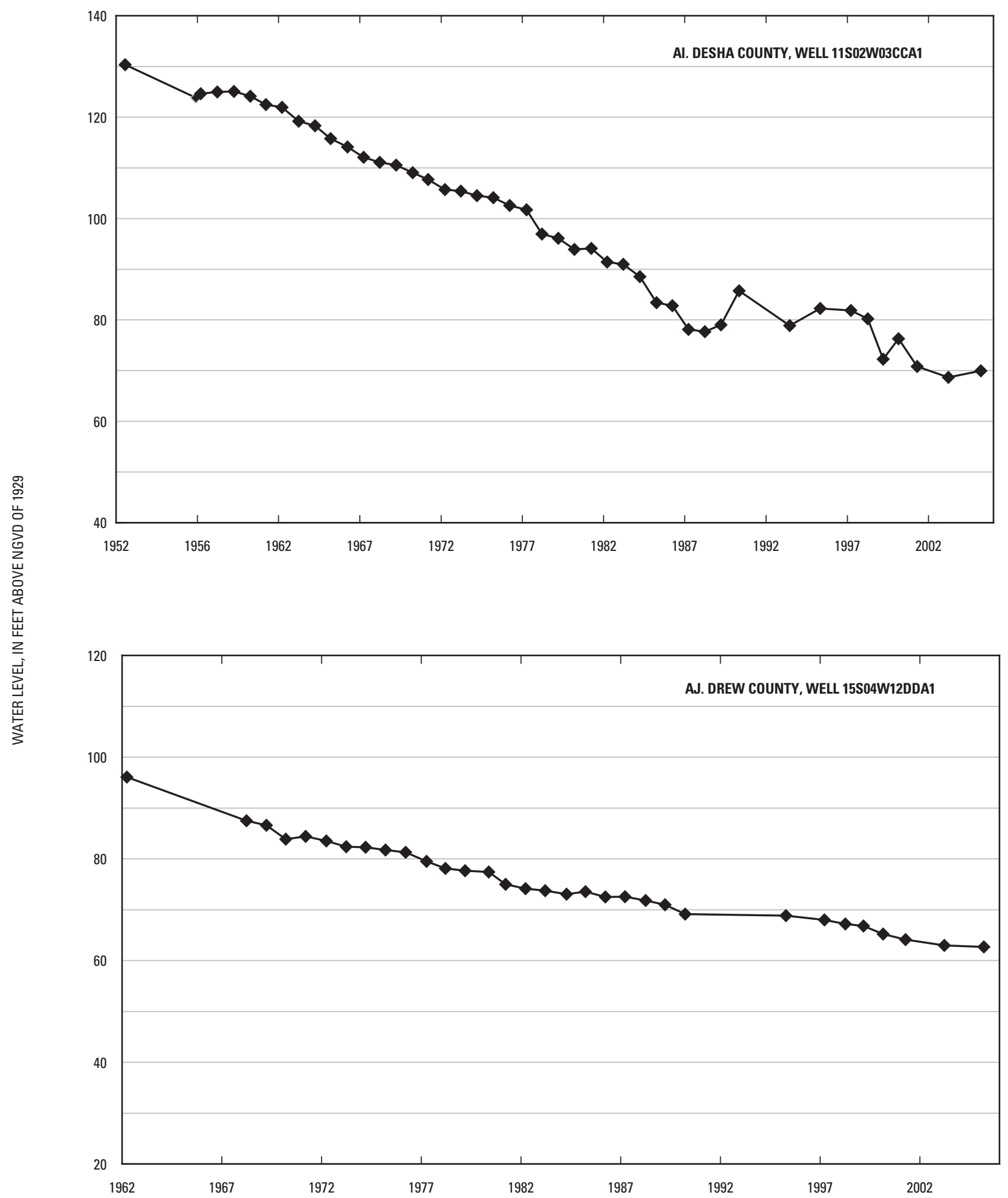

Figure 4. Water-level hydrographs for selected wells completed in the Sparta-Memphis aquifer in Arkansas and Louisiana. Well location listed in appendix 1.-Continued 
16 Status of Water Levels and Selected Water-Quality Conditions in the Sparta-Memphis Aquifer in Arkansas and the Status of Water Levels in the Sparta Aquifer in Louisiana, Spring 2005

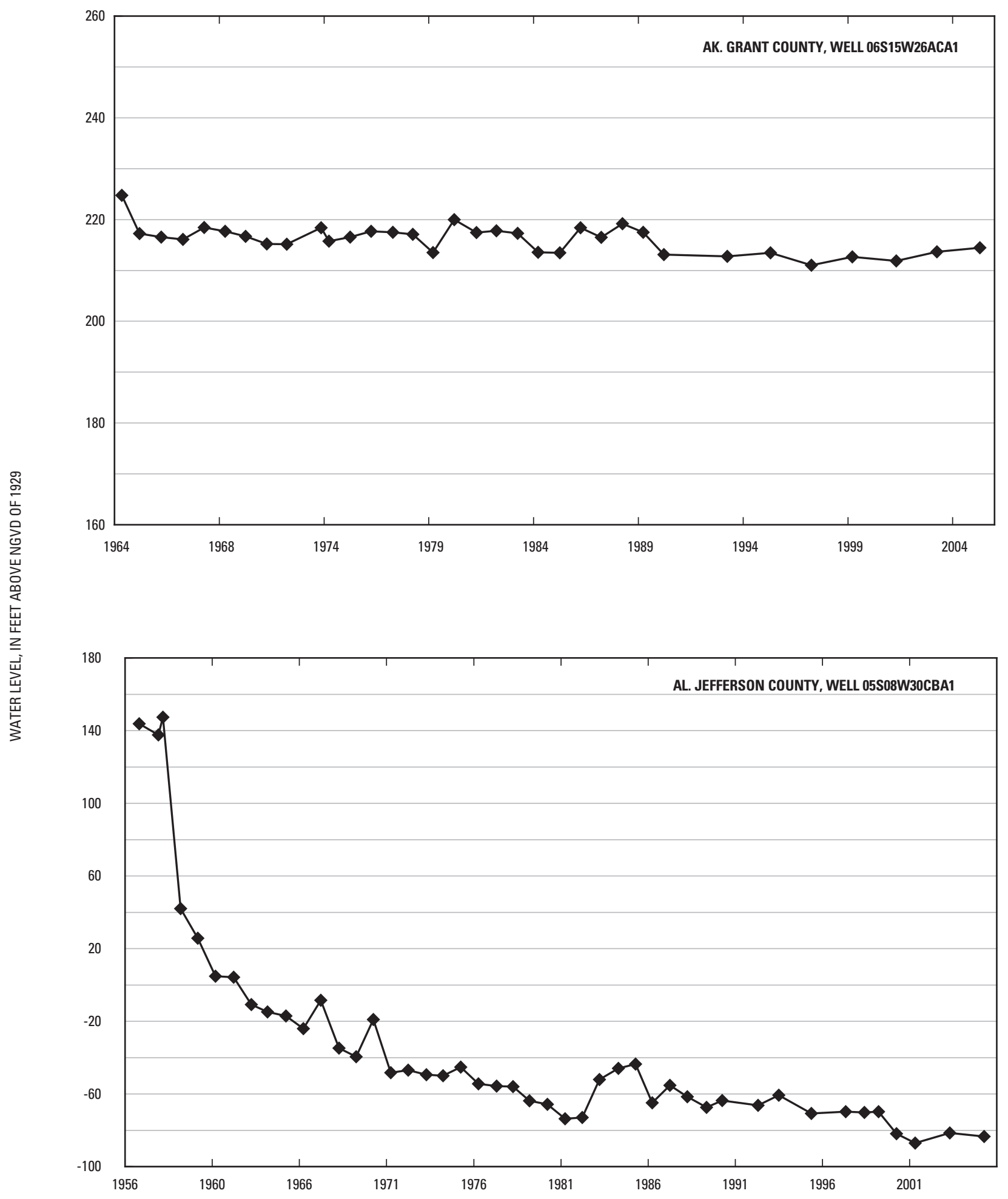

Figure 4. Water-level hydrographs for selected wells completed in the Sparta-Memphis aquifer in Arkansas and Louisiana. Well location listed in appendix 1.-Continued 

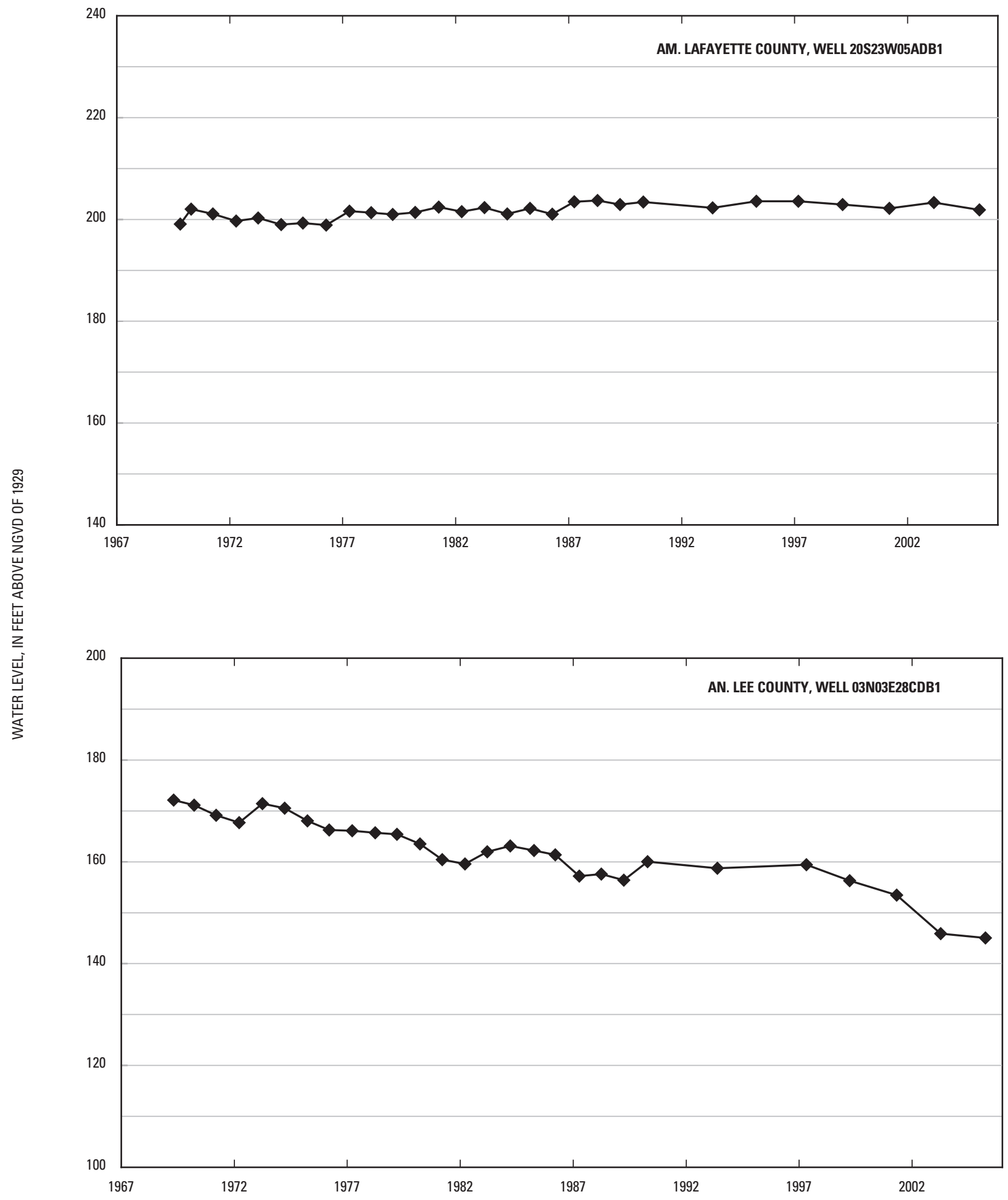

Figure 4. Water-level hydrographs for selected wells completed in the Sparta-Memphis aquifer in Arkansas and Louisiana. Well location listed in appendix 1.-Continued 
18 Status of Water Levels and Selected Water-Quality Conditions in the Sparta-Memphis Aquifer in Arkansas and the Status of Water Levels in the Sparta Aquifer in Louisiana, Spring 2005

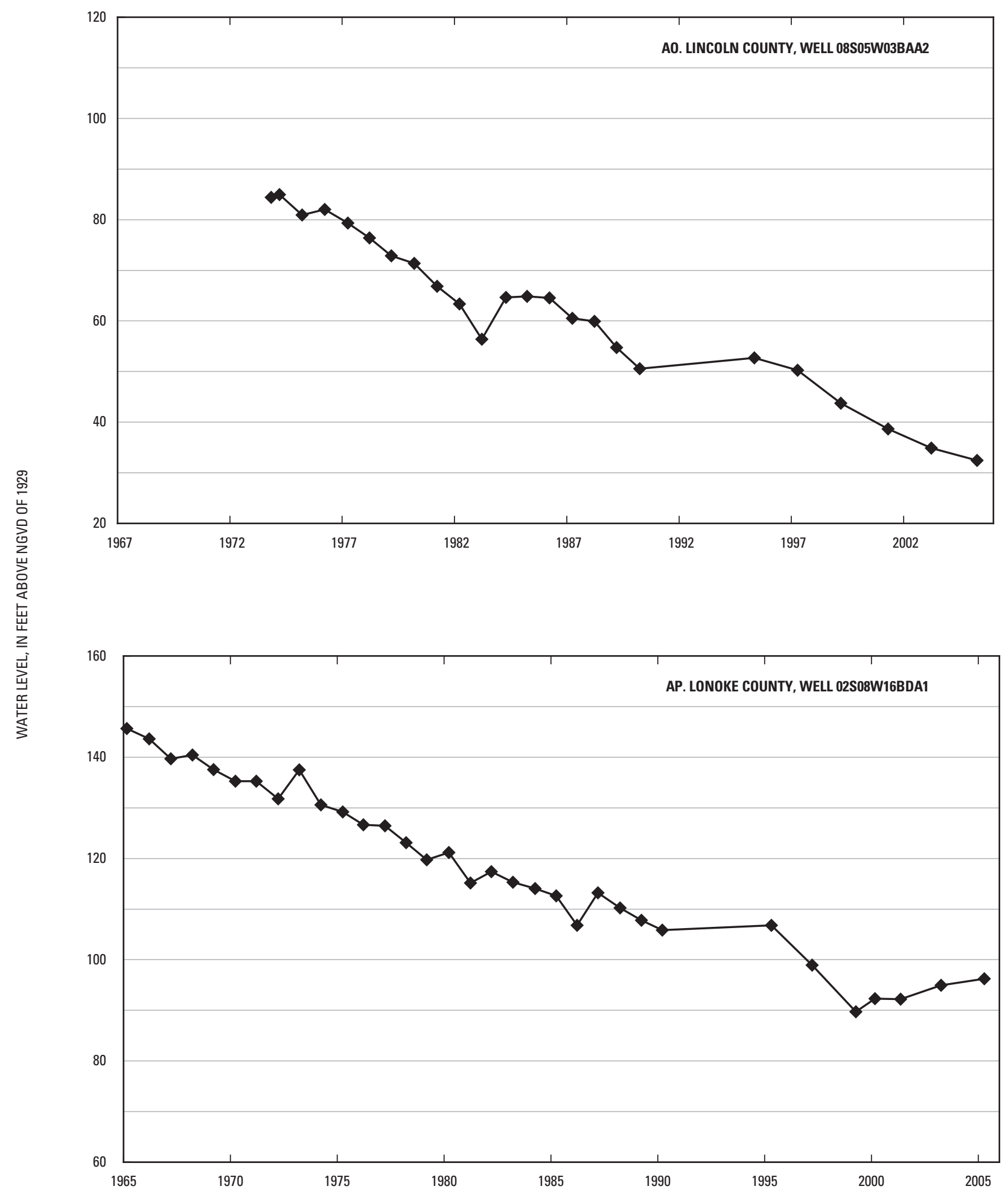

Figure 4. Water-level hydrographs for selected wells completed in the Sparta-Memphis aquifer in Arkansas and Louisiana. Well location listed in appendix 1.-Continued 


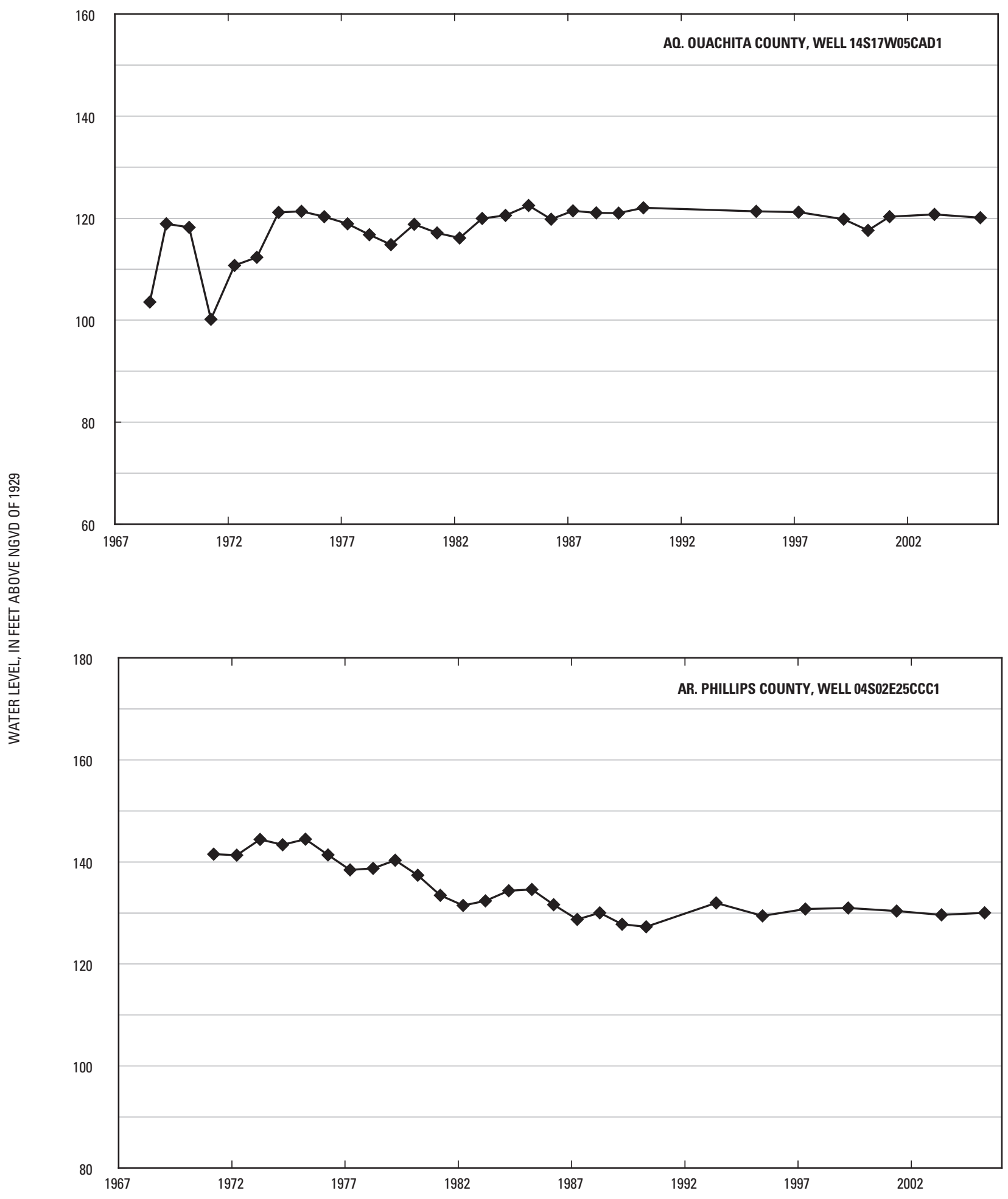

Figure 4. Water-level hydrographs for selected wells completed in the Sparta-Memphis aquifer in Arkansas and Louisiana. Well location listed in appendix 1.-Continued 
20 Status of Water Levels and Selected Water-Quality Conditions in the Sparta-Memphis Aquifer in Arkansas and the Status of Water Levels in the Sparta Aquifer in Louisiana, Spring 2005
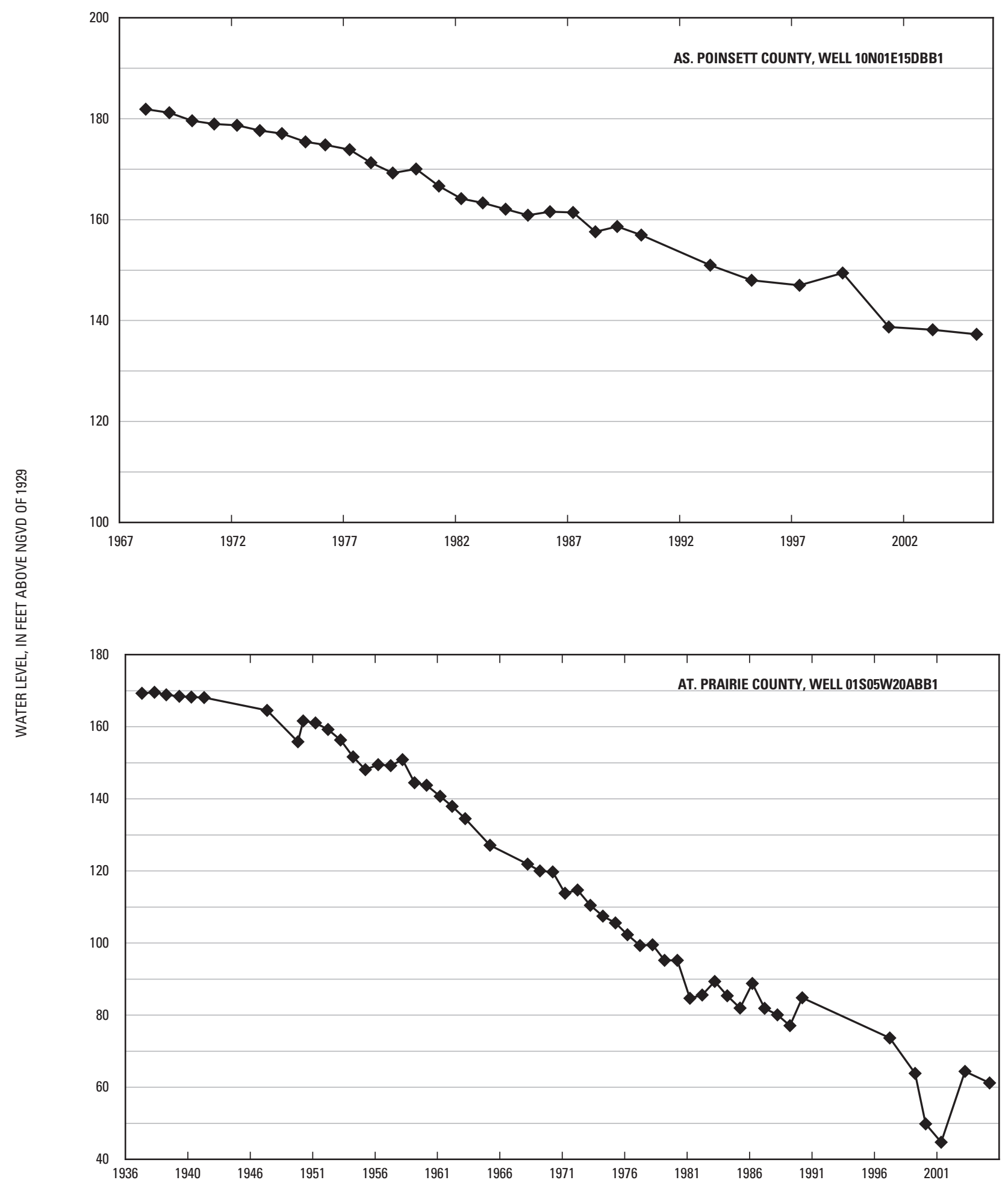

Figure 4. Water-level hydrographs for selected wells completed in the Sparta-Memphis aquifer in Arkansas and Louisiana. Well location listed in appendix 1.-Continued 


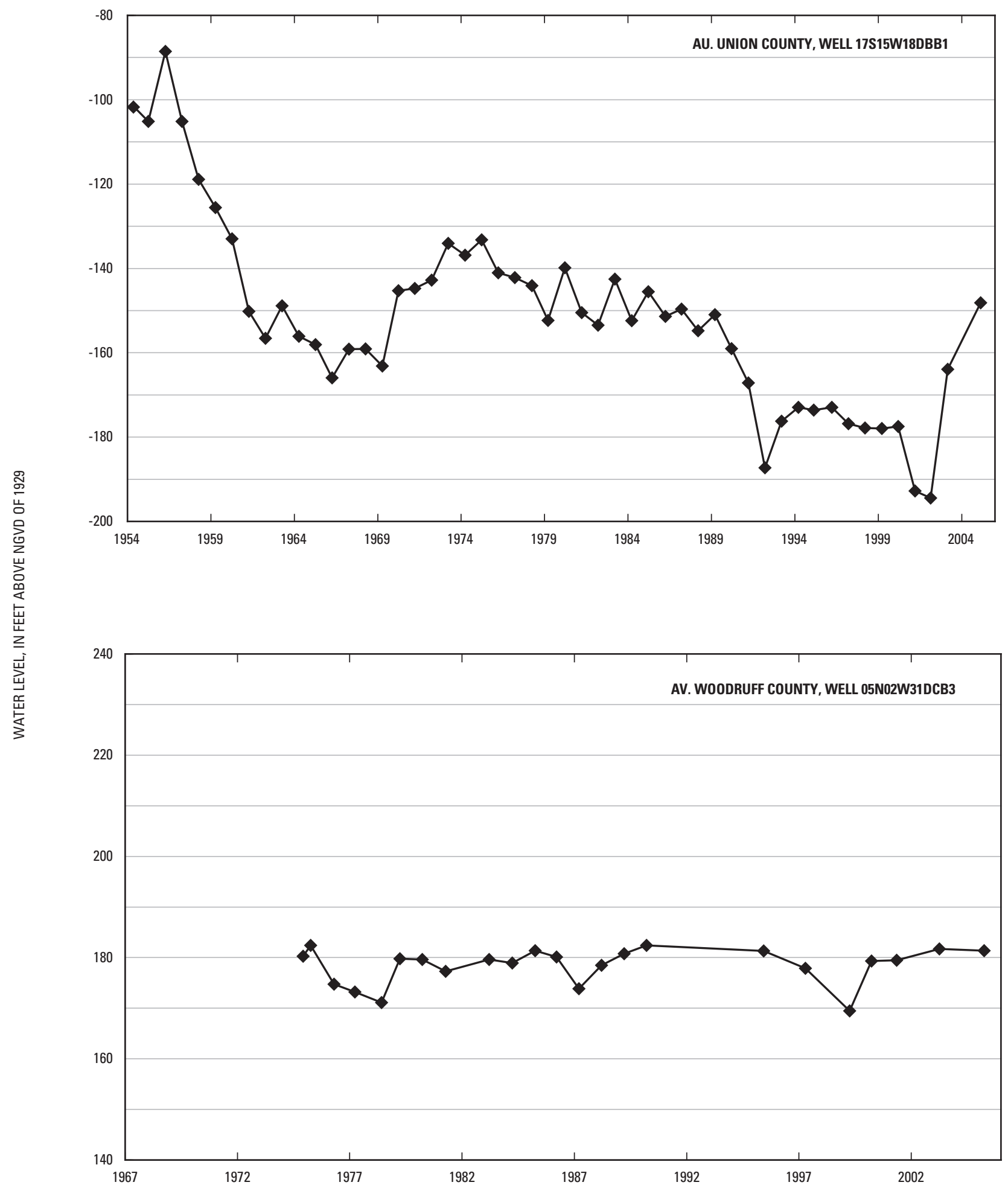

Figure 4. Water-level hydrographs for selected wells completed in the Sparta-Memphis aquifer in Arkansas and Louisiana. Well location listed in appendix 1.-Continued 
22 Status of Water Levels and Selected Water-Quality Conditions in the Sparta-Memphis Aquifer in Arkansas and the Status of Water Levels in the Sparta Aquifer in Louisiana, Spring 2005

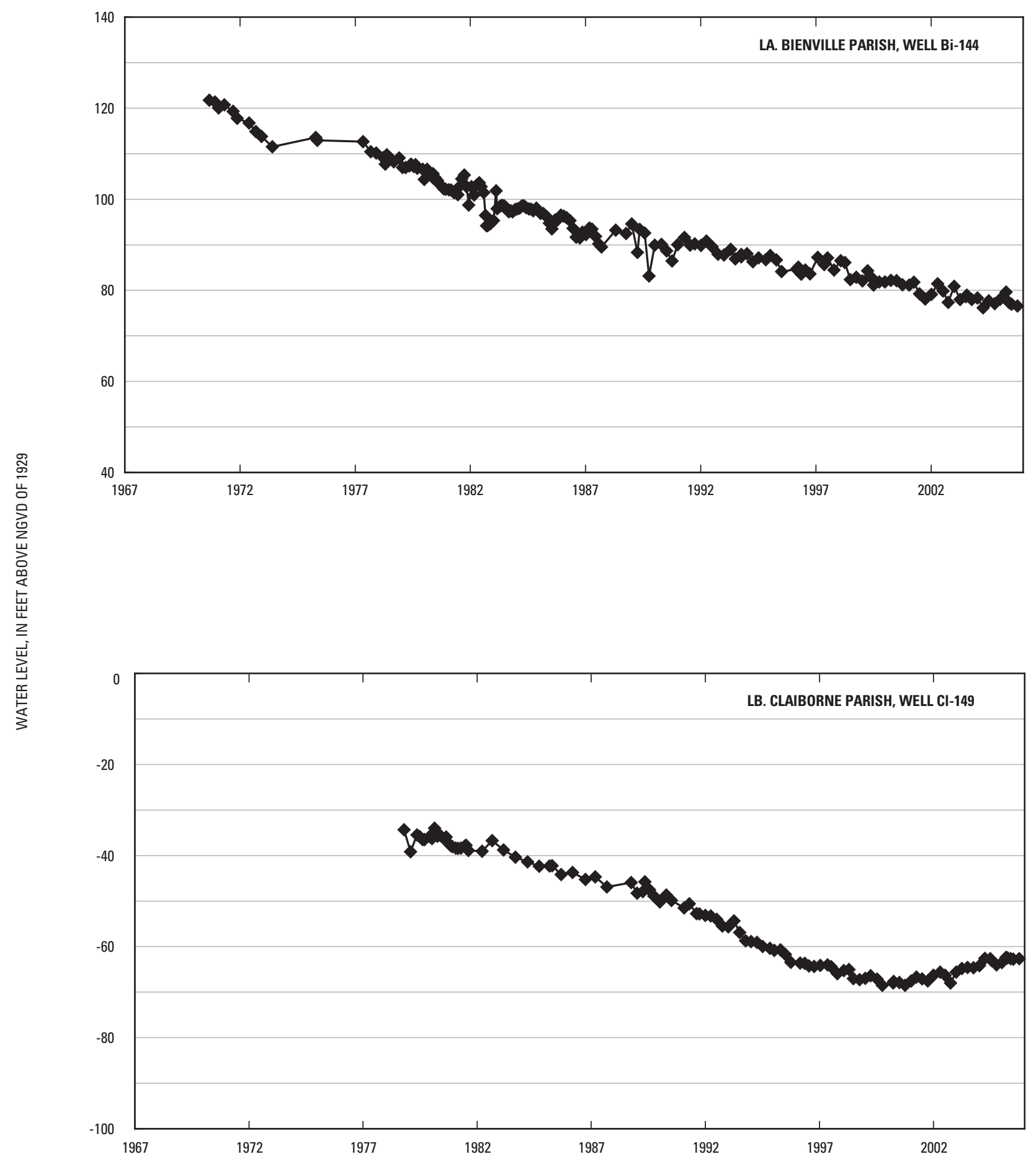

Figure 4. Water-level hydrographs for selected wells completed in the Sparta-Memphis aquifer in Arkansas and Louisiana. Well location listed in appendix 1.-Continued 


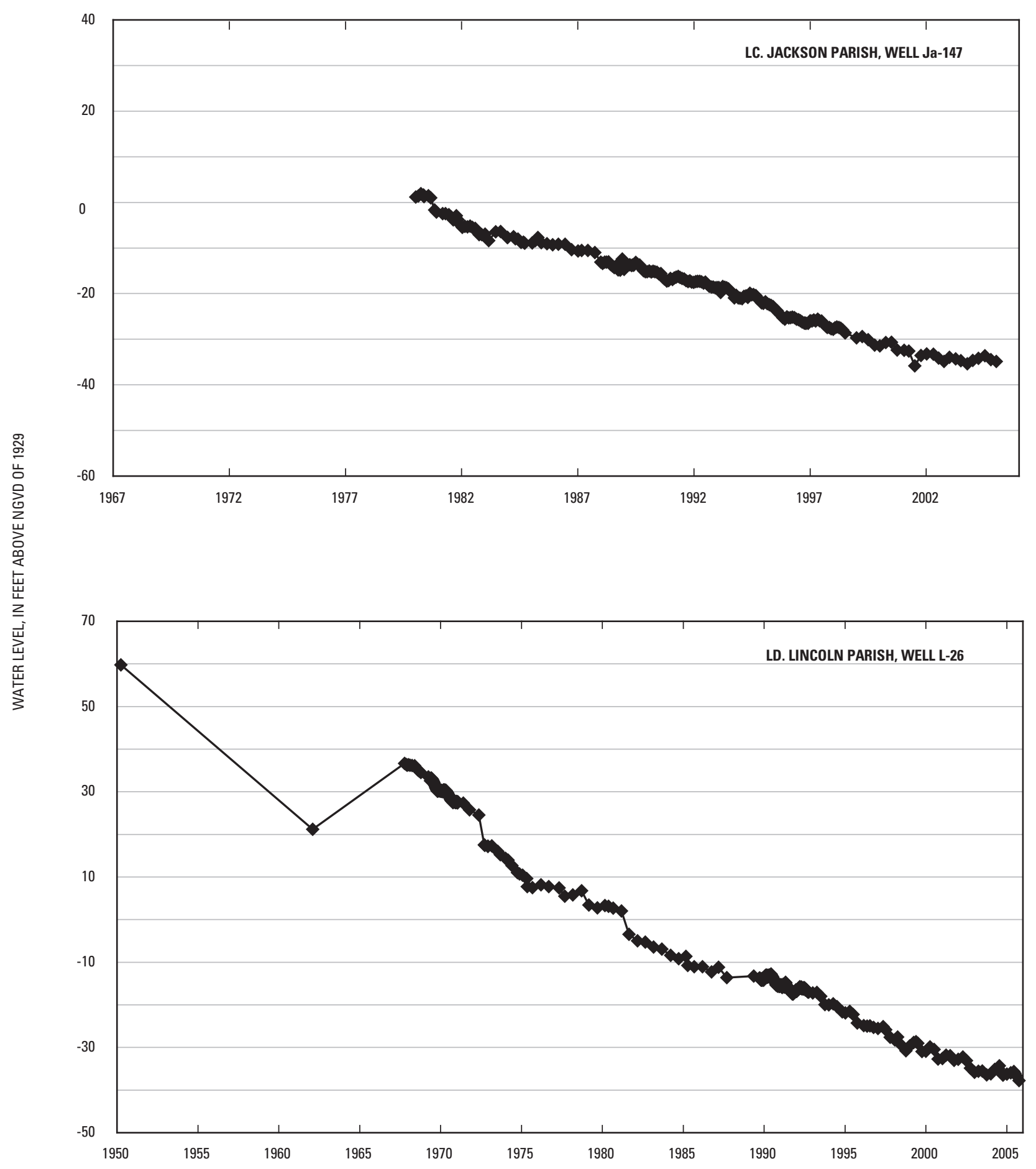

Figure 4. Water-level hydrographs for selected wells completed in the Sparta-Memphis aquifer in Arkansas and Louisiana. Well location listed in appendix 1.-Continued 
24 Status of Water Levels and Selected Water-Quality Conditions in the Sparta-Memphis Aquifer in Arkansas and the Status of Water Levels in the Sparta Aquifer in Louisiana, Spring 2005

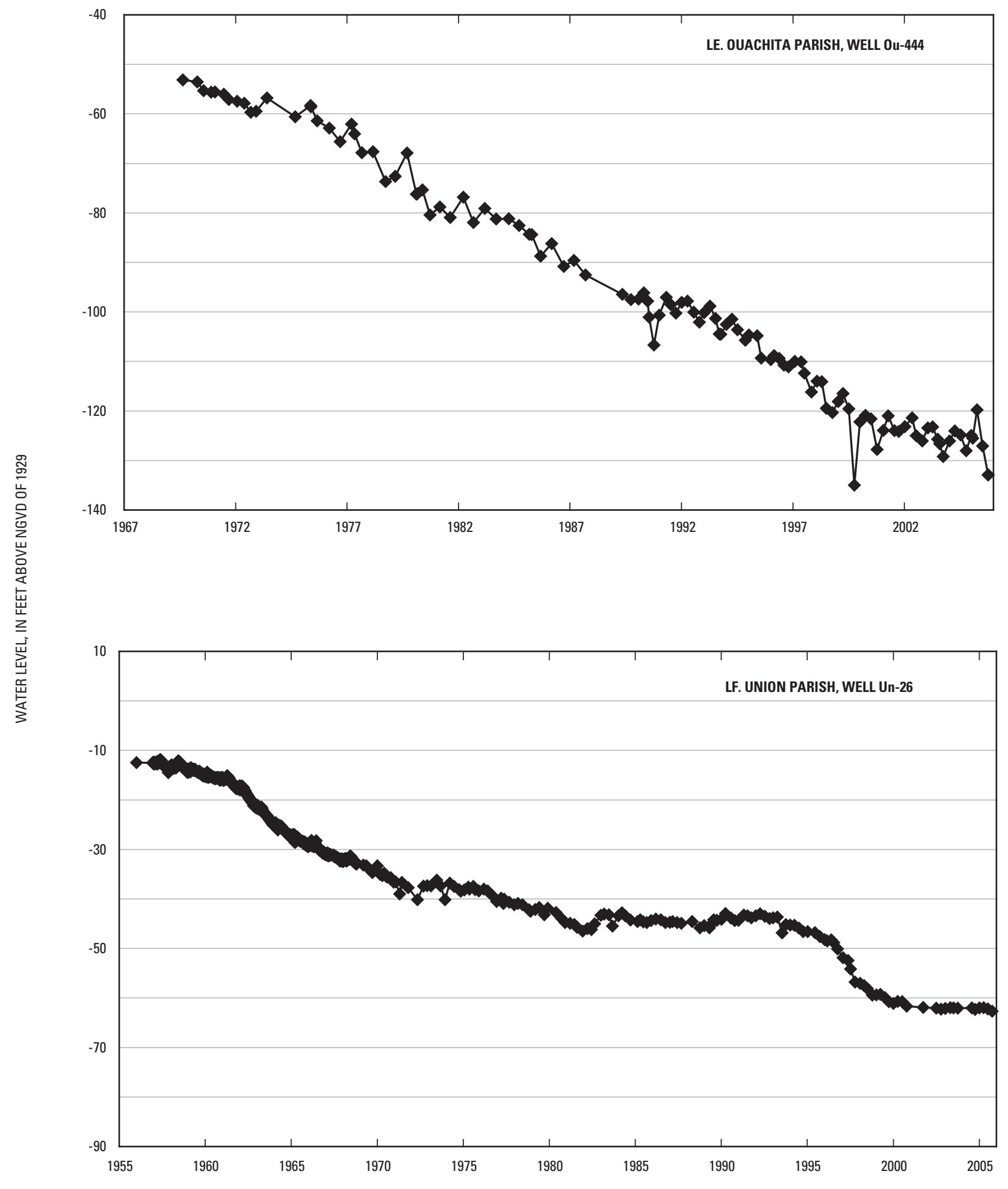

Figure 4. Water-level hydrographs for selected wells completed in the Sparta-Memphis aquifer in Arkansas and Louisiana. Well location listed in appendix 1.-Continued 


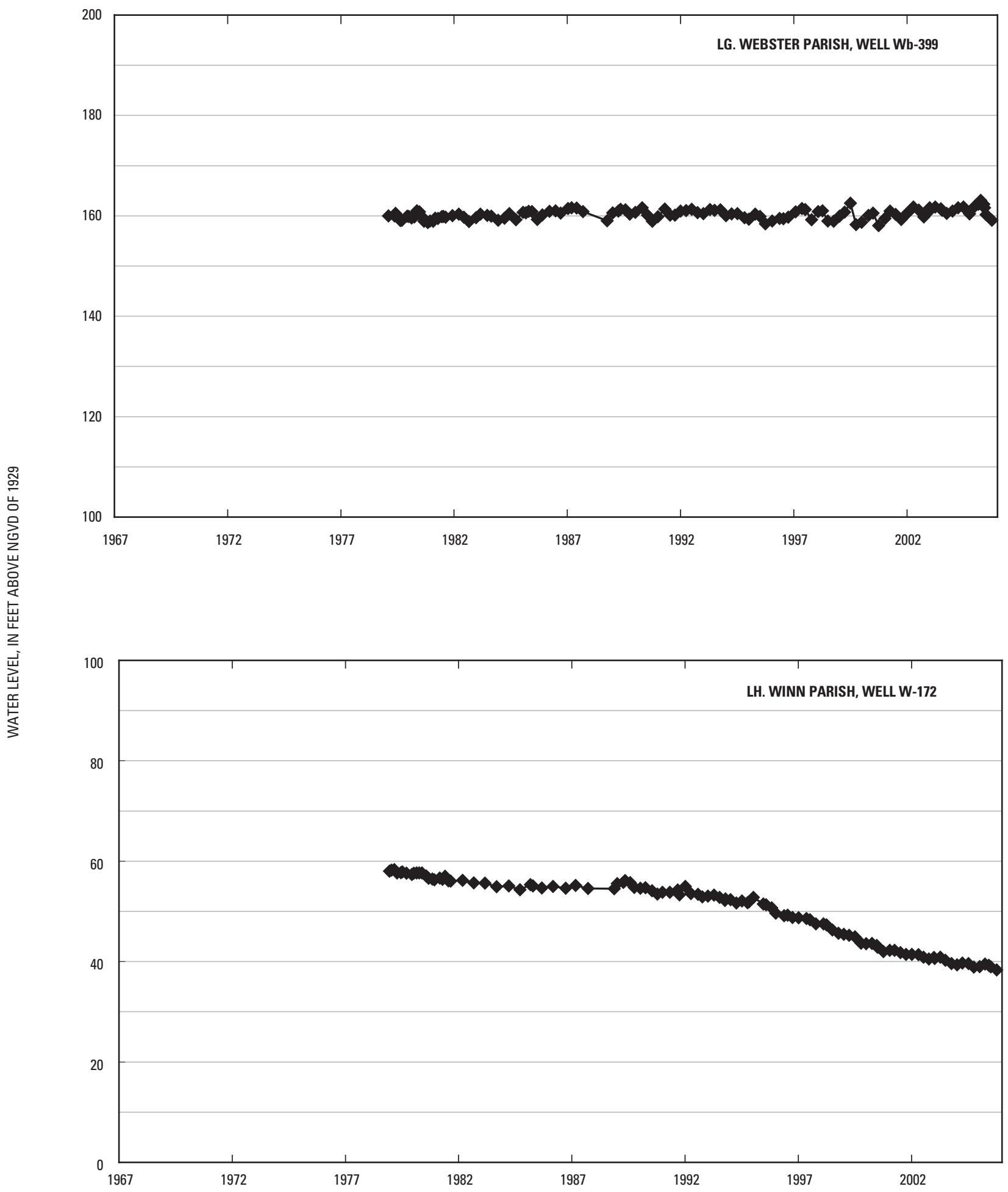

Figure 4. Water-level hydrographs for selected wells completed in the Sparta-Memphis aquifer in Arkansas and Louisiana. Well location listed in appendix 1.-Continued 


\section{Water-Quality Conditions}

Water samples were collected from 61 wells in the spring of 2005 and measured onsite for specific conductance and temperature in Arkansas (appendix 3). Wells were purged until the water temperature and specific conductance stabilized before samples were collected to ensure a representative sample.

Specific-conductance data indicate regionally diverse zones of mineralized water within the aquifers across the study area. Specific conductance ranged from 32.7 microsiemens per centimeter $(\mu \mathrm{S} / \mathrm{cm})$ in Ouachita County to about $1,356 \mu \mathrm{S} / \mathrm{cm}$ in Lee County. The median specific conductance was 278 $\mu \mathrm{S} / \mathrm{cm}$ and the mean specific conductance was $362 \mu \mathrm{S} / \mathrm{cm}$. Along the western border of the Sparta-Memphis aquifer in Arkansas near the outcrop area, specific conductance is lowgenerally less than $200 \mu \mathrm{S} / \mathrm{cm}$, and increases to the east and south. This gradual increase of specific conductance continues south to the Louisiana State line.

Although there is a regional increase in specific conductance to the east and south, anomalous increases occur in some parts of the study area. Relatively high specific conductance values (greater than $700 \mu \mathrm{S} / \mathrm{cm}$ and less than $1,400 \mu \mathrm{S} / \mathrm{cm}$ ) occur in Arkansas, Ashley, Lee, Monroe, Phillips, and Union Counties. Arkansas, Lee, Monroe, and Phillips Counties are adjacent in an area that has relatively high specific conduc- tance values. Morris and Bush (1986) and Broom and others (1984) cited upward leakage of saltwater from the Nacatoch aquifer of Cretaceous age into the Sparta aquifer through a fault or abandoned oil and gas wells as possible explanations for these anomalies. Relatively high specific conductance values occur near the depression in Union County. This increase in specific conductance may be because of leakage of water with greater conductance from an underlying aquifer. A previous study documented several specific-conductance values greater than 2,000 $\mu \mathrm{S} / \mathrm{cm}$ for ground water from the Sparta aquifer in Union County in 1984 (Broom and others, 1984).

The statistical distribution of specific-conductance values in 2005 has changed from the distribution of specific-conductance values in 2003. The distribution of specific conductance for 2005 and 2003 is shown in figure 5. The number of specific-conductance samples collected in 2005 and 2003 are 61 and 70, respectively. The samples collected in 2005 have a larger portion of samples in the $0-200 \mu \mathrm{S} / \mathrm{cm}$ range when compared to the 2003 distribution. The samples collected in 2003 have a larger portion of samples in the 401-600 $\mathrm{SS} / \mathrm{cm}$ and 601-800 $\mu \mathrm{S} / \mathrm{cm}$ ranges when compared to the 2005 distribution. More than half of the wells sampled in 2005 are different wells than those sampled in 2003. The difference in the geographical distribution of the wells sampled may account for the difference in distribution of specific-conductance values from 2005 and 2003.

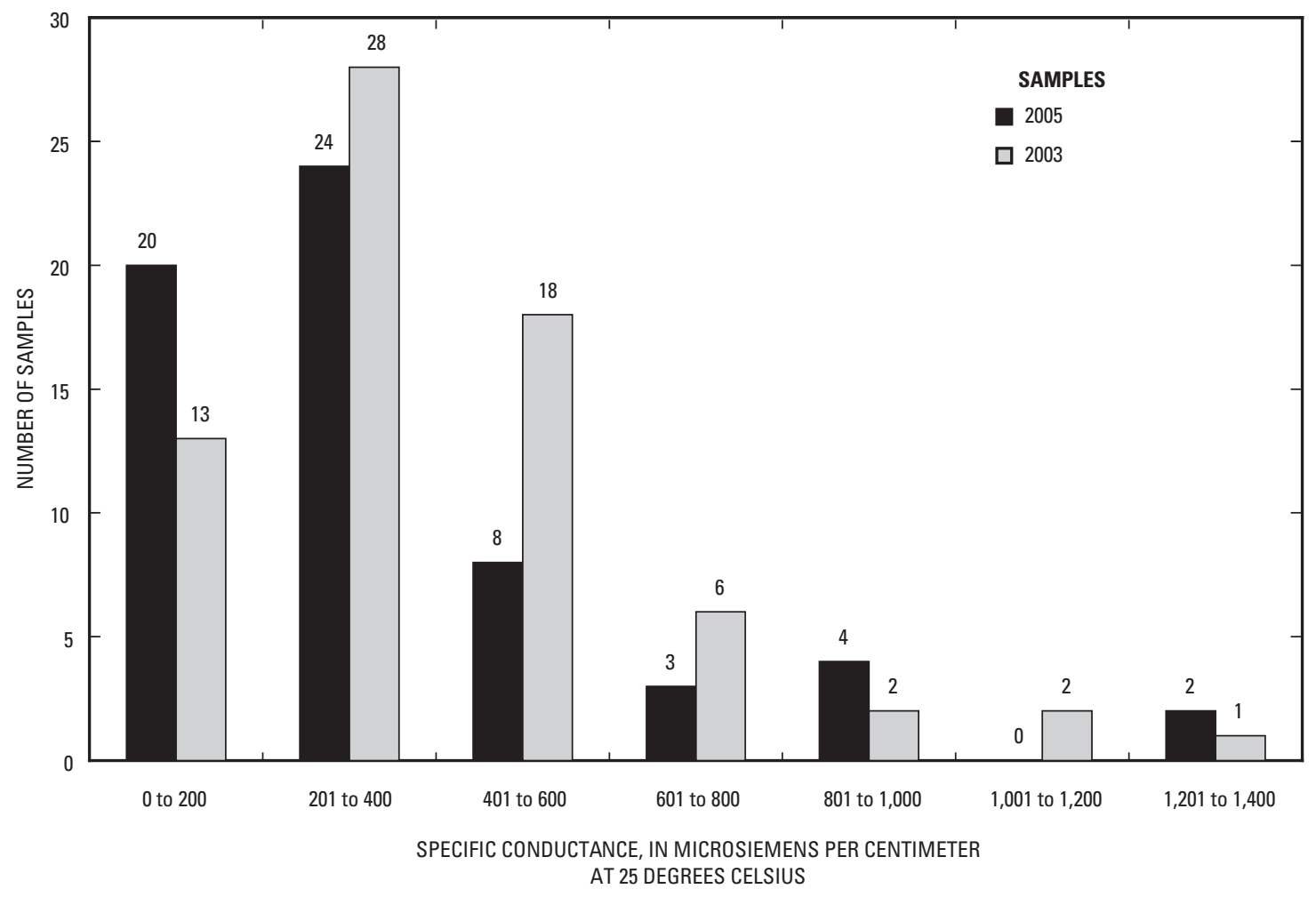

Figure 5. Distribution of specific conductance in samples from wells screened in the Sparta-Memphis aquifer in Arkansas, 2005 and 2003. 


\section{Summary}

The U.S. Geological Survey in cooperation with the Arkansas Soil and Water Conservation Commission, the Arkansas Geological Commission, and the Louisiana Department of Transportation and Development has monitored water levels in the Sparta-Memphis aquifer since the 1920's. A combined report for Arkansas and Louisiana has been produced every 4 years since 1997 to describe ground-water levels in the aquifer and provide information for the management of this valuable resource. This report presents the status of water levels in the Sparta-Memphis aquifer in Arkansas and the Sparta aquifer in Louisiana and water-quality conditions in the Sparta-Memphis aquifer in Arkansas.

Total water use in the Sparta-Memphis aquifer in Arkansas and Louisiana generally increased from 1980 to 1995 , then remained the same until 2000. In 1980, total water use in Arkansas and Louisiana was about $251 \mathrm{Mgal} / \mathrm{d}$. In 1995 and 2000, total water use in Arkansas and Louisiana was about $355 \mathrm{Mgal} / \mathrm{d}$, an increase of 29 percent over the 1980 total water use.

The 2005 potentiometric-surface map of the Sparta-Memphis aquifer shows the altitude to which water would have stood in tightly cased wells completed in the aquifers. The map is based upon water-level data collected in 333 wells in Arkansas and 121 wells in Louisiana, in the Sparta-Memphis aquifer during the spring of 2005. The highest water-level altitude measured in Arkansas was $327 \mathrm{ft}$ above NGVD of 1929, located in Grant County in the outcrop at the western boundary of the study area; the lowest water-level altitude was $189 \mathrm{ft}$ below NGVD of 1929 in Union County. The highest waterlevel altitude measured in Louisiana was $246 \mathrm{ft}$ above NGVD of 1929, located in Bossier Parish in the outcrop area near the western boundary of the study area; the lowest water-level altitude was $226 \mathrm{ft}$ below NGVD of 1929 in central Ouachita Parish.

Three large depressions are shown in Arkansas on the 2005 potentiometric-surface map, centered in Columbia, Jefferson, and Union Counties, as a result of large withdrawals for industrial and public supplies. The depression centered in Jefferson County deepened and expanded in recent years into Prairie County where withdrawals for agricultural, irrigation, and public supplies have increased. This depression has approximately the same shape and depth as on the 2003 potentiometric-surface map. The depressions in Columbia and Union Counties are elongated east to west because of large industrial withdrawals and coalesce at or near the Columbia and Union County line. The depression in Union County has receded from Union Parish, Louisiana. The depression in Columbia County is similar in shape and depth as on the 2003 potentiometric-surface map. A broad depression is shown in western Poinsett and Cross Counties in Arkansas.
In Louisiana, three major pumping centers are shown on the 2005 potentiometric map in Ouachita, Jackson, and Lincoln Parishes. Water withdrawals from these major pumping centers primarily is used for public- and industrial supply purposes. Withdrawals from Ouachita and Lincoln Parishes and Union County, Arkansas, primarily for industrial purposes, have caused the resulting cones of depression to coalesce so that the $-40 \mathrm{ft}$ potentiometric contour encircles the three pumping centers.

Seven smaller depressions are evident on the 2005 Sparta-Memphis aquifer potentiometric-surface map, located in Webster and Winn Parishes, Louisiana, and Calhoun, Cleveland, western Columbia, Desha, and Lafayette Counties, Arkansas. The depression in Calhoun County initially was shown on the 1996-1997 potentiometric surface. The depression in Desha County initially was shown on the 1999 potentiometric surface. The depressions in Webster and Winn Parishes were shown as early as 1975 . The depressions in Cleveland, western Columbia, and Lafayette Counties initially were shown on the 2003 potentiometric surface.

A map of differences in water-level measurements between 2001 and 2005 was constructed using the difference between water-level measurements from 294 wells in Arkansas and 29 wells in Louisiana. The difference in water level between 2001 and 2005 ranged from -30.1 to $44.6 \mathrm{ft}$. The largest rise of $44.6 \mathrm{ft}$ in water level measured was in Union County in Arkansas. The largest decline of $30.1 \mathrm{ft}$ in water level measured was in Columbia County in Arkansas. Between 1999 and 2003, a large public supply converted from a primary source of ground water to a primary source of surface water. The decrease in withdrawals from the ground water resulted in the large rises in Columbia County. When public supply changed to surface water as the primary source, an industrial user decreased the amount of public-supplied water and increased self-supplied ground water. The increase in self-supplied ground water may have contributed to the largest decline in water level.

Areas with a general rise in water levels in Arkansas are shown in Arkansas, Columbia, Craighead, Jefferson, Prairie and the western half of Union Counties. The area around El Dorado had rises as much as $44.6 \mathrm{ft}$, with seven wells showing a rise of $20 \mathrm{ft}$ or greater, which was an annual rise of $5 \mathrm{ft}$ or greater. The rise in water level around El Dorado coincides with water conservation methods initiated in 1999 and the conversion of large industrial users to surface water from the Ouachita River in December 2004. Areas in Arkansas with a general decline in water level are shown in western Bradley, eastern Calhoun, Cleveland, Cross, Desha, Drew, Lafayette, Lee, Lincoln, Lonoke, Poinsett, and the eastern half of Union Counties.

In Louisiana, the water-level difference map showed a general rise in water levels in northern Claiborne, northern Webster, and northwestern Union Parishes mainly because of a decrease in industrial withdrawals in southern Arkansas, particularly Union County. Another rise in water level was indicated in western Jackson Parish where industrial with- 
drawals have been reduced. The remainder of the study area in Louisiana showed a general decrease in water level ranging from $1.5 \mathrm{ft}$ in Claiborne Parish at well Cl-116 to $6.1 \mathrm{ft}$ in Union Parish at well Un-134.

In Arkansas, hydrographs were constructed for wells with a minimum of 25 years of water-level measurements. During the period 1981-2005, the county mean annual water level rose only in Columbia, Lafayette and Ouachita Counties. Mean annual declines were between $0.5 \mathrm{ft} / \mathrm{yr}$ and $0.0 \mathrm{ft} / \mathrm{yr}$ in Dallas, Grant, Phillips, and Woodruff Counties. Mean annual declines were between $1.0 \mathrm{ft} / \mathrm{yr}$ and $0.5 \mathrm{ft} / \mathrm{yr}$ in Calhoun, Cleveland, Craighead, Cross, Desha, Drew, Jefferson, Lee, and Union Counties. Mean annual declines were between $1.5 \mathrm{ft} / \mathrm{yr}$ and $1.0 \mathrm{ft} / \mathrm{yr}$ in Arkansas, Bradley, Lincoln, Lonoke, Poinsett, and Prairie Counties.

In Louisiana, hydrographs were constructed using a minimum of 25 years of water-level measurements. At well Cl-149 in Claiborne Parish, a decline in water level is evident from 1981 until late 1999 at a rate of approximately $1.7 \mathrm{ft} / \mathrm{yr}$. Since 1999, a water-level increase of approximately $1.1 \mathrm{ft} / \mathrm{yr}$ is evident at $\mathrm{Cl}-149$, because of a reduction of industrial withdrawals in Union County, Arkansas.

Water samples were collected from 61 wells in the spring of 2005 and measured onsite for specific conductance and temperature in Arkansas. Specific conductance ranged from $32.7 \mu \mathrm{S} / \mathrm{cm}$ in Ouachita County to about $1,356 \mu \mathrm{S} / \mathrm{cm}$ in Lee County. The median specific conductance was $278 \mu \mathrm{S} / \mathrm{cm}$ and the mean specific conductance was $362 \mu \mathrm{S} / \mathrm{cm}$. Along the western border of the Sparta-Memphis aquifer in Arkansas near the outcrop area, ground water has low specific conductance-generally less than $200 \mu \mathrm{S} / \mathrm{cm}$. Specific conductance increases to the east and south. Relatively high specific conductance values (greater than $700 \mu \mathrm{S} / \mathrm{cm}$ ) occur near the water-level depression in Union County. This increase in specific conductance may be because of leakage of water with greater conductance from an underlying aquifer. Relatively high specific conductance values also occur in Arkansas, Ashley, Lee, Monroe, and Phillips Counties.

The statistical distribution of specific conductance values in 2005 has changed from the distribution of specific conductance values in 2003. The samples collected in 2005 have a larger portion of samples in the $0-200 \mu \mathrm{S} / \mathrm{cm}$ range when compared to the 2003 distribution. The samples collected in 2003 have a larger portion of samples in the $401-600 \mu \mathrm{S} / \mathrm{cm}$ and $601-800 \mu \mathrm{S} / \mathrm{cm}$ ranges when compared to the 2005 distribution. 


\section{Selected References}

Broom, M.E., Kraemer, T.F., and Bush, W.V., 1984, A reconnaissance study of saltwater contamination in the El Dorado aquifer, Union County, Arkansas: U.S. Geological Survey Water-Resources Investigations Report 84-4012, 47 p.

Edds, Joe, and Fitzpatrick, D.J., 1985, Maps showing altitude of the potentiometric surface and changes in water levels of the Sparta Sand and Memphis Sand aquifers in eastern Arkansas, spring 1984: U.S. Geological Survey WaterResources Investigations Report 85-4223, 1 sheet.

Edds, Joe, and Fitzpatrick, D.J., 1989, Altitude of the potentiometric surface and changes in water levels in the SpartaMemphis aquifer in eastern and southern Arkansas, spring 1986: U.S. Geological Survey Water-Resources Investigations Report 88-4042, 1 sheet.

Fenneman, N.M., 1938, Physiography of eastern United States: New York, McGraw-Hill Book Co., Inc., 689 p.

Holland, T.W., 2004, Estimated water use in Arkansas, 2000: U.S. Geological Survey Scientific Investigations Report 2004-5230, 31 p.

Holland, T.W., 1999, Water use in Arkansas, 1995: U.S. Geological Survey Open-File Report 99-188, 1 sheet.

Holland, T.W., 1993, Use of water in Arkansas, 1990: U.S. Geological Survey Open-File Report 93-48, pamphlet.

Holland, T.W., 1987, Use of water in Arkansas, 1985: Arkansas Geological Commission Water Resources Summary Number 14, 30 p.

Holland, T.W., and Ludwig, A.H., 1981, Use of water in Arkansas: Arkansas Geological Commission, Water Resources Summary Number 14, 30 p.

Hosman, R.L., 1982, Outcropping Tertiary units in southern Arkansas: U.S. Geological Survey Miscellaneous Investigations Series I-1405, 1 sheet.

Hosman, R.L., Long, A.T., Lambert, T.W., and others, 1968, Tertiary aquifers in the Mississippi Embayment: U.S. Geological Survey Professional Paper 448-D, 29 p.

Joseph, R.L., 1997, Potentiometric surface of the Sparta aquifer in eastern and south-central Arkansas and northcentral Louisiana, and the Memphis aquifer in east-central Arkansas, October 1996-July 1997: U.S. Geological Survey Water-Resources Investigations Report 97-4282, 19 p.

Joseph, R.L., 2000, Status of water levels and selected waterquality conditions in the Sparta and Memphis aquifers in eastern and south-central Arkansas, 1999: U.S. Geological Survey Water-Resources Investigations Report 00-4009, $34 \mathrm{p}$.
Lovelace, J.K., 1990, Water use in Louisiana, 1990: Louisiana Department of Transportation and Development Water Resources Special Report no. 6, 131 p.

Lovelace, J.K., and Johnson, P.M., 1996, Water use in Louisiana, 1995; Louisiana Department of Transportation and Development Water Resources Special Report no. 11, 127 p.

Lurry, D.L., 1987, Pumpage of water in Louisiana, 1985: Louisiana Department of Transportation and Development, Office of Public Works Water Resources Special Report no. 4, $14 \mathrm{p}$.

Morris, E.E., and Bush, W.V., 1986, Extent and source of saltwater intrusion into the alluvial aquifer near Brinkley, Arkansas, 1984: U.S. Geological Survey Water-Resources Investigations Report 85-4322, 123 p.

Payne, J.N., 1968, Hydrologic significance of the lithofacies of the Sparta Sand in Arkansas, Louisiana, Mississippi, and Texas: U.S. Geological Survey Professional Paper 569-A, $17 \mathrm{p}$.

Petersen, J.C., Broom, M.E., and Bush, W.V., 1985, Geohydrologic units of the Gulf Coastal Plain in Arkansas: U.S. Geological Survey Water-Resources Investigations Report 85-4116, 20 p.

Ryals, G.N., 1980, Potentiometric surface maps of the Sparta Sand, northern Louisiana and southern Arkansas, 1900, 1965, 1975, and 1980: U.S. Geological Survey Open-file Report 80-1180, 1 sheet.

Sargent, B.P., 2002, Water use in Louisiana, 2000: Louisiana Department of Transportation and Development Water Resources Special Report no. 15, 133 p.

Schrader, T.P., 2006, Status of water levels and selected water-quality conditions in the Sparta-Memphis aquifer in Arkansas, spring-summer, 2003: U.S. Geological Survey Scientific Investigations Report 2006-5021, 43 p.

Schrader, T.P., 2004, Status of water levels and selected water-quality conditions in the Sparta-Memphis aquifer in Arkansas and the Sparta aquifer in Louisiana, spring-summer 2001: U.S. Geological Survey Scientific Investigations Report 2004-5055, 52 p.

Snider, J.L., Calandro, A.J., and Shampine, W.J., 1972, Water resources of Union Parish, Louisiana: Department of Conservation, Louisiana Geological Survey, and Louisiana Department of Public Works Water Resources Bulletin No. $17,68 \mathrm{p}$.

Stanton, G.P., 1997, Potentiometric surface and specific conductance of the Sparta and Memphis aquifers in eastern and south-central Arkansas, 1995: U.S. Geological Survey Water-Resources Investigations Report 97-4119, 16 p. 
30 Status of Water Levels and Selected Water-Quality Conditions in the Sparta-Memphis Aquifer in Arkansas and the Status of Water Levels in the Sparta Aquifer in Louisiana, Spring 2005

Tomaszewski, D.J., Lovelace, J.K., and Ensminger, P.A., 2002, Water withdrawals and trends in ground-water levels and stream discharge in Louisiana: Louisiana Department of Transportation and Development, Water Resources Technical Report No. 68, 30 p.

U.S. Geological Survey, variously dated, National field manual for the collection of water-quality data: U.S. Geological Survey Techniques of Water-Resources Investigations, book 9, chaps. A1-A9, available online at http://pubs.water.usgs. gov/twri9A.

Walter, W.H., 1982, Pumpage of water in Louisiana, 1980: Louisiana Department of Transportation and Development, Office of Public Works Water Resources Special Report no. $3,15 \mathrm{p}$. 


\section{Appendixes 1-3}


32 Status of Water Levels and Selected Water-Quality Conditions in the Sparta-Memphis Aquifer in Arkansas and the Status of Water Levels in the Sparta Aquifer in Louisiana, Spring 2005

Appendix 1. Water-level data collected during spring 2005 from wells completed in the Sparta-Memphis aquifer in Arkansas and Louisiana.

[NGVD of 1929, National Geodetic Vertical Datum of 1929; Horizontal datum is NAD of 1983]

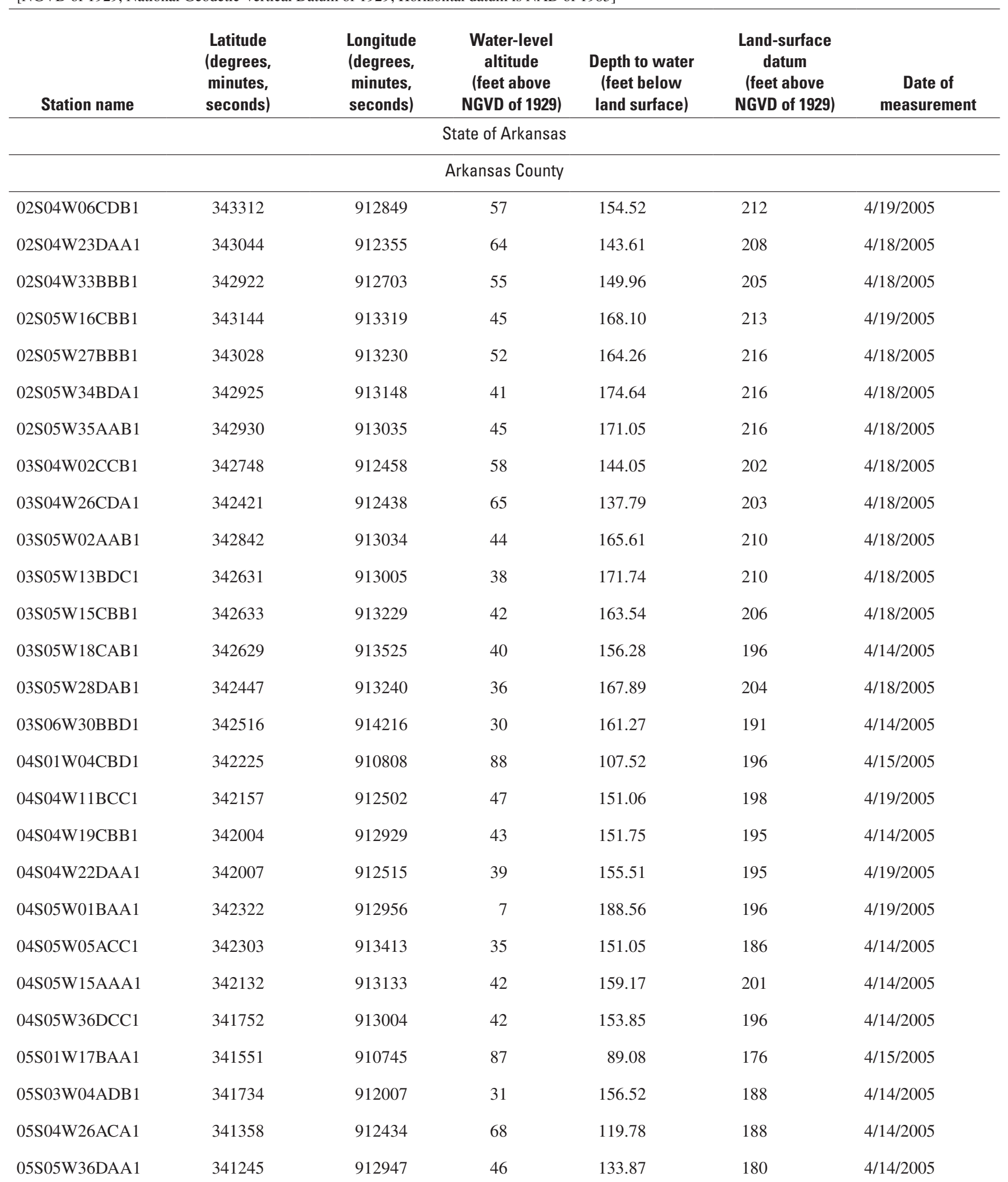


Appendix 1. Water-level data collected during spring 2005 from wells completed in the Sparta-Memphis aquifer in Arkansas and Louisiana. - Continued

[NGVD of 1Y<y, INanonaı veodetic Vertical Datum of 1929; Horizontal datum is NAD of 1983]

\begin{tabular}{|c|c|c|c|c|c|c|}
\hline Station name & $\begin{array}{c}\text { Latitude } \\
\text { (degrees, } \\
\text { minutes, } \\
\text { seconds) }\end{array}$ & $\begin{array}{c}\text { Longitude } \\
\text { (degrees, } \\
\text { minutes, } \\
\text { seconds) }\end{array}$ & $\begin{array}{c}\text { Water-level } \\
\text { altitude } \\
\text { (feet above } \\
\text { NGVD of 1929) }\end{array}$ & $\begin{array}{l}\text { Depth to water } \\
\text { (feet below } \\
\text { land surface) }\end{array}$ & $\begin{array}{c}\text { Land-surface } \\
\text { datum } \\
\text { (feet above } \\
\text { NGVD of 1929) }\end{array}$ & $\begin{array}{c}\text { Date of } \\
\text { measurement }\end{array}$ \\
\hline \multicolumn{7}{|c|}{ Arkansas County-Continued } \\
\hline 06S02W06ABB1 & 341228 & 911620 & 79 & 102.32 & 181 & $4 / 14 / 2005$ \\
\hline 06S02W22CDB1 & 340904 & 911331 & 88 & 98.12 & 186 & $4 / 14 / 2005$ \\
\hline 06S03W27BAA1 & 340859 & 912009 & 68 & 112.51 & 181 & $4 / 14 / 2005$ \\
\hline 07S02W28ABA1 & 340340 & 911411 & 83 & 98.23 & 181 & $4 / 14 / 2005$ \\
\hline 15S07W32CDD1 & 332118 & 915101 & 51 & 138.72 & 190 & $3 / 23 / 2005$ \\
\hline 17S09W15ACC1 & 331334 & 920116 & 82 & 17.97 & 100 & $3 / 23 / 2005$ \\
\hline \multicolumn{7}{|c|}{ Bradley County } \\
\hline 12S09W31CCB1 & 333711 & 920444 & 45 & 186.36 & 231 & $3 / 23 / 2005$ \\
\hline 13S09W06ACA1 & 333648 & 920437 & 43 & 191.82 & 235 & $3 / 18 / 2005$ \\
\hline 13S09W06ACB2 & 333647 & 920417 & 41 & 166.75 & 208 & $3 / 18 / 2005$ \\
\hline 13S13W32CDA1 & 333227 & 922742 & 38 & 170.27 & 208 & $3 / 17 / 2005$ \\
\hline 13S15W36CBD1 & 333227 & 923532 & 81 & 77.12 & 158 & $3 / 11 / 2005$ \\
\hline 14S13W05BBD1 & 333207 & 922802 & 33 & 156.36 & 189 & $3 / 17 / 2005$ \\
\hline 14S13W12CCB1 & 333040 & 922404 & 34 & 170.89 & 205 & $3 / 17 / 2005$ \\
\hline 14S15W16BAA1 & 333055 & 923912 & 50 & 96.29 & 146 & $3 / 11 / 2005$ \\
\hline 15S13W20BDC1 & 332411 & 922807 & 84 & 24.75 & 109 & $3 / 11 / 2005$ \\
\hline \multicolumn{7}{|c|}{ Chicot County } \\
\hline 13S03W22DAD1 & 333312 & 912308 & 67 & 68.28 & 135 & $3 / 23 / 2005$ \\
\hline \multicolumn{7}{|c|}{ Cleveland County } \\
\hline 08S12W13BDD1 & 340133 & 921638 & 114 & 145.06 & 259 & $3 / 29 / 2005$ \\
\hline
\end{tabular}


34 Status of Water Levels and Selected Water-Quality Conditions in the Sparta-Memphis Aquifer in Arkansas and the Status of Water Levels in the Sparta Aquifer in Louisiana, Spring 2005

Appendix 1. Water-level data collected during spring 2005 from wells completed in the Sparta-Memphis aquifer in Arkansas and Louisiana. - Continued

[NGVD of 1929, National Geodetic Vertical Datum of 1929; Horizontal datum is NAD of 1983]

\begin{tabular}{|c|c|c|c|c|c|c|}
\hline Station name & $\begin{array}{l}\text { Latitude } \\
\text { (degrees, } \\
\text { minutes, } \\
\text { seconds) }\end{array}$ & $\begin{array}{c}\text { Longitude } \\
\text { (degrees, } \\
\text { minutes, } \\
\text { seconds) }\end{array}$ & $\begin{array}{c}\text { Water-level } \\
\text { altitude } \\
\text { (feet above } \\
\text { NGVD of 1929) }\end{array}$ & $\begin{array}{l}\text { Depth to water } \\
\text { (feet below } \\
\text { land surface) }\end{array}$ & $\begin{array}{c}\text { Land-surface } \\
\text { datum } \\
\text { (feet above } \\
\text { NGVD of 1929) }\end{array}$ & $\begin{array}{c}\text { Date of } \\
\text { measurement }\end{array}$ \\
\hline \multicolumn{7}{|c|}{ Cleveland County-Continued } \\
\hline 09S11W01DCA1 & 335729 & 921134 & 18 & 207.21 & 225 & $3 / 29 / 2005$ \\
\hline 09S11W11CDB1 & 335623 & 921251 & 71 & 161.94 & 233 & $3 / 29 / 2005$ \\
\hline 10S09W23CDC1 & 334918 & 920021 & 57 & 162.56 & 220 & $3 / 29 / 2005$ \\
\hline 10S09W35ACD1 & 334758 & 915957 & 64 & 154.84 & 219 & $3 / 29 / 2005$ \\
\hline 15S20W20CCB1 & 332453 & 931215 & 156 & 216.13 & 372 & $3 / 09 / 2005$ \\
\hline 16S20W08DCC1 & 332114 & 931141 & 85 & 317.23 & 402 & $3 / 09 / 2005$ \\
\hline 16S20W18ACD1 & 332053 & 931237 & 75 & 262.50 & 337 & $3 / 09 / 2005$ \\
\hline 16S21W14CBB1 & 332049 & 931517 & 83 & 198.31 & 281 & $3 / 09 / 2005$ \\
\hline 16S21W20DAD1 & 331955 & 931736 & 102 & 248.24 & 350 & $3 / 09 / 2005$ \\
\hline 16S22W22CCD1 & 331948 & 932225 & 193 & 146.87 & 340 & $3 / 09 / 2005$ \\
\hline 17S19W30ABB1 & 331406 & 930650 & 26 & 221.74 & 248 & $3 / 09 / 2005$ \\
\hline 17S20W17CDA1 & 331520 & 931201 & 8 & 317.24 & 325 & $3 / 10 / 2005$ \\
\hline 17S20W36ABC1 & 331307 & 930755 & 39 & 296.42 & 335 & $3 / 10 / 2005$ \\
\hline 17S21W01BBC1 & 331743 & 931424 & 35 & 269.75 & 305 & $3 / 10 / 2005$ \\
\hline 17S21W08DCA1 & 331613 & 931758 & 89 & 210.87 & 300 & 3/09/2005 \\
\hline 17S21W11DCC2 & 331609 & 931449 & 21 & 278.57 & 300 & $2 / 22 / 2005$ \\
\hline 17S21W11DCC3 & 331609 & 931449 & 18 & 280.37 & 298 & $3 / 10 / 2005$ \\
\hline 17S21W17BAB1 & 331608 & 931820 & 84 & 203.27 & 287 & $3 / 09 / 2005$ \\
\hline 17S22W21ABD1 & 331517 & 932304 & 213 & 81.62 & 295 & $3 / 09 / 2005$ \\
\hline 17S22W22ABB1 & 331522 & 932210 & 184 & 137.00 & 321 & $3 / 09 / 2005$ \\
\hline
\end{tabular}


Appendix 1. Water-level data collected during spring 2005 from wells completed in the Sparta-Memphis aquifer in Arkansas and Louisiana. - Continued

[NGVD of 1929, National Geodetic Vertical Datum of 1929; Horizontal datum is NAD of 1983]

\begin{tabular}{|c|c|c|c|c|c|c|}
\hline Station name & $\begin{array}{c}\text { Latitude } \\
\text { (degrees, } \\
\text { minutes, } \\
\text { seconds) }\end{array}$ & $\begin{array}{c}\text { Longitude } \\
\text { (degrees, } \\
\text { minutes, } \\
\text { seconds) }\end{array}$ & $\begin{array}{c}\text { Water-level } \\
\text { altitude } \\
\text { (feet above } \\
\text { NGVD of 1929) }\end{array}$ & $\begin{array}{l}\text { Depth to water } \\
\text { (feet below } \\
\text { land surface) }\end{array}$ & $\begin{array}{c}\text { Land-surface } \\
\text { datum } \\
\text { (feet above } \\
\text { NGVD of 1929) }\end{array}$ & $\begin{array}{c}\text { Date of } \\
\text { measurement }\end{array}$ \\
\hline \multicolumn{7}{|c|}{ Columbia County-Continued } \\
\hline 17S22W23BBB1 & 331521 & 932137 & 204 & 136.11 & 340 & $3 / 09 / 2005$ \\
\hline 18S20W10CAA1 & 331054 & 931016 & 12 & 277.51 & 290 & $3 / 15 / 2005$ \\
\hline 18S21W01ACC1 & 331223 & 931339 & -5 & 299.63 & 295 & $3 / 10 / 2005$ \\
\hline 18S21W17ACD1 & 331034 & 931759 & 86 & 228.80 & 315 & $3 / 09 / 2005$ \\
\hline 19S23W10ABD1 & 330644 & 932833 & 198 & 43.52 & 242 & $3 / 09 / 2005$ \\
\hline 19S23W11CDA2 & 330609 & 932744 & 196 & 52.45 & 248 & $3 / 09 / 2005$ \\
\hline 19S23W11DDB1 & 330605 & 932722 & 192 & 54.03 & 246 & $3 / 09 / 2005$ \\
\hline 19S23W14BAB2 & 330555 & 932752 & 194 & 50.46 & 244 & $3 / 09 / 2005$ \\
\hline 20S22W03DCC1 & 330138 & 932236 & 162 & 52.07 & 214 & $3 / 10 / 2005$ \\
\hline 20S22W11ACD1 & 330109 & 932133 & 164 & 107.13 & 271 & $3 / 10 / 2005$ \\
\hline 14N05E36CBC1 & 354751 & 903100 & 209 & 10.76 & 220 & $4 / 06 / 2005$ \\
\hline 15N03E31ADA1 & 355314 & 904807 & 214 & 55.90 & 270 & $4 / 06 / 2005$ \\
\hline 15N04E20ADB1 & 355506 & 904043 & 320 & 118.18 & 438 & $4 / 06 / 2005$ \\
\hline 15N05E29DBB1 & 355360 & 903433 & 237 & 21.08 & 258 & $4 / 06 / 2005$ \\
\hline 15N06E18ACA1 & 355544 & 902858 & 215 & 15.31 & 230 & $4 / 06 / 2005$ \\
\hline \multicolumn{7}{|c|}{ Crittenden County } \\
\hline 05N08E11CCA2 & 350345 & 901300 & 188 & 22.94 & 211 & $4 / 05 / 2005$ \\
\hline 06N07E01DAD2 & 350958 & 901738 & 186 & 22.53 & 209 & $4 / 05 / 2005$ \\
\hline 06N09E08DCC1 & 350850 & 900922 & 207 & 8.10 & 215 & $4 / 05 / 2005$ \\
\hline 06N09E23AAB1 & 350745 & 900553 & 160 & 61.57 & 222 & $4 / 05 / 2005$ \\
\hline
\end{tabular}


36 Status of Water Levels and Selected Water-Quality Conditions in the Sparta-Memphis Aquifer in Arkansas and the Status of Water Levels in the Sparta Aquifer in Louisiana, Spring 2005

Appendix 1. Water-level data collected during spring 2005 from wells completed in the Sparta-Memphis aquifer in Arkansas and Louisiana. - Continued

[NGVD of 1929, National Geodetic Vertical Datum of 1929; Horizontal datum is NAD of 1983]

\begin{tabular}{|c|c|c|c|c|c|c|}
\hline Station name & $\begin{array}{l}\text { Latitude } \\
\text { (degrees, } \\
\text { minutes, } \\
\text { seconds) }\end{array}$ & $\begin{array}{l}\text { Longitude } \\
\text { (degrees, } \\
\text { minutes, } \\
\text { seconds) }\end{array}$ & $\begin{array}{c}\text { Water-level } \\
\text { altitude } \\
\text { (feet above } \\
\text { NGVD of 1929) }\end{array}$ & $\begin{array}{l}\text { Depth to water } \\
\text { (feet below } \\
\text { land surface) }\end{array}$ & $\begin{array}{c}\text { Land-surface } \\
\text { datum } \\
\text { (feet above } \\
\text { NGVD of 1929) }\end{array}$ & $\begin{array}{c}\text { Date of } \\
\text { measurement }\end{array}$ \\
\hline \multicolumn{7}{|c|}{ Crittenden County-Continued } \\
\hline 07N09E14BAC1 & 351348 & 900628 & 190 & 27.42 & 217 & $4 / 05 / 2005$ \\
\hline 06N04E06ACA1 & 351004 & 904238 & 156 & 201.92 & 358 & $4 / 05 / 2005$ \\
\hline 07N05E04ADD1 & 351538 & 903330 & 173 & 36.08 & 209 & $4 / 05 / 2005$ \\
\hline 08N02E18BDB1 & 351908 & 905538 & 145 & 82.72 & 228 & $4 / 05 / 2005$ \\
\hline 09N03E22AAD1 & 352403 & 904512 & 148 & 130.19 & 278 & $4 / 05 / 2005$ \\
\hline 09N04E30DCA1 & 352232 & 904218 & 164 & 265.67 & 429 & $4 / 05 / 2005$ \\
\hline \multicolumn{7}{|c|}{ Dallas County } \\
\hline 07S14W30DCC1 & 340431 & 923360 & 215 & 119.65 & 335 & $3 / 07 / 2005$ \\
\hline 07S14W31AAA1 & 340425 & 923334 & 220 & 109.53 & 330 & $3 / 07 / 2005$ \\
\hline 07S16W20CAB1 & 340555 & 924545 & 297 & 24.97 & 322 & $3 / 07 / 2005$ \\
\hline 09S14W01BDC1 & 335754 & 922919 & 186 & 78.66 & 265 & $3 / 07 / 2005$ \\
\hline 09S16W19CAA1 & 335605 & 924701 & 254 & 6.03 & 260 & $3 / 07 / 2005$ \\
\hline 10S13W34ACA2 & 334829 & 922458 & 121 & 151.47 & 272 & $3 / 07 / 2005$ \\
\hline 10S14W27CDB1 & 334908 & 923138 & 238 & 31.93 & 270 & $3 / 07 / 2005$ \\
\hline 10S15W18BCC1 & 335120 & 924120 & 252 & 75.78 & 328 & $3 / 07 / 2005$ \\
\hline \multicolumn{7}{|c|}{ Desha County } \\
\hline 09S02W26AAC1 & 335346 & 911521 & 84 & 68.91 & 153 & $3 / 24 / 2005$ \\
\hline 09S04W28DDD1 & 335310 & 913007 & 52 & 112.54 & 165 & $3 / 24 / 2005$ \\
\hline 10S02W26CCC2 & 334750 & 911624 & 77 & 71.24 & 148 & $3 / 24 / 2005$ \\
\hline 10S04W11CBC1 & 335034 & 912905 & 58 & 102.90 & 161 & $3 / 24 / 2005$ \\
\hline
\end{tabular}


Appendix 1. Water-level data collected during spring 2005 from wells completed in the Sparta-Memphis aquifer in Arkansas and Louisiana. - Continued

[NGVD of 1929, National Geodetic Vertical Datum of 1929; Horizontal datum is NAD of 1983]

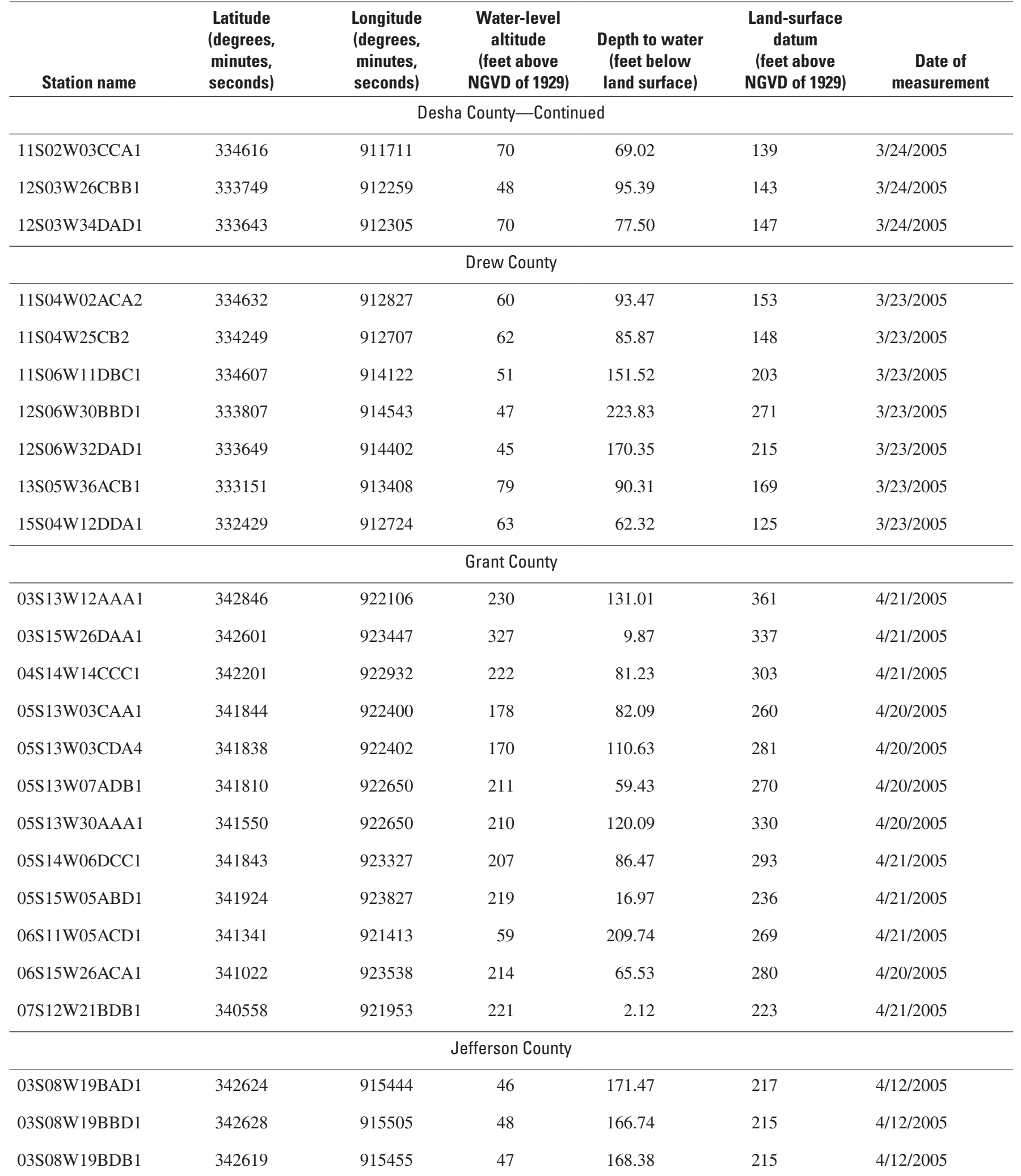


38 Status of Water Levels and Selected Water-Quality Conditions in the Sparta-Memphis Aquifer in Arkansas and the Status of Water Levels in the Sparta Aquifer in Louisiana, Spring 2005

Appendix 1. Water-level data collected during spring 2005 from wells completed in the Sparta-Memphis aquifer in Arkansas and Louisiana. -Continued

[NGVD of 1929, National Geodetic Vertical Datum of 1929; Horizontal datum is NAD of 1983]

\begin{tabular}{|c|c|c|c|c|c|c|}
\hline Station name & $\begin{array}{c}\text { Latitude } \\
\text { (degrees, } \\
\text { minutes, } \\
\text { seconds) }\end{array}$ & $\begin{array}{l}\text { Longitude } \\
\text { (degrees, } \\
\text { minutes, } \\
\text { seconds) }\end{array}$ & $\begin{array}{c}\text { Water-level } \\
\text { altitude } \\
\text { (feet above } \\
\text { NGVD of 1929) }\end{array}$ & $\begin{array}{l}\text { Depth to water } \\
\text { (feet below } \\
\text { land surface) }\end{array}$ & $\begin{array}{c}\text { Land-surface } \\
\text { datum } \\
\text { (feet above } \\
\text { NGVD of 1929) }\end{array}$ & $\begin{array}{c}\text { Date of } \\
\text { measurement }\end{array}$ \\
\hline \multicolumn{7}{|c|}{ Jefferson County-Continued } \\
\hline 03S09W23BBD1 & 342627 & 915713 & 59 & 165.45 & 224 & $4 / 12 / 2005$ \\
\hline 03S10W27AAD1 & 342502 & 920434 & 96 & 126.25 & 222 & $4 / 12 / 2005$ \\
\hline 03S11W22ABC1 & 342651 & 921058 & 135 & 174.99 & 310 & $4 / 13 / 2005$ \\
\hline 04S07W17BCC1 & 342140 & 914742 & 32 & 168.40 & 200 & $4 / 12 / 2005$ \\
\hline 04S10W29ADB1 & 342025 & 920625 & 60 & 207.96 & 268 & $4 / 13 / 2005$ \\
\hline 04S11W14BAD1 & 342220 & 921000 & 90 & 309.76 & 400 & $4 / 13 / 2005$ \\
\hline 05S08W30ADB1 & 341452 & 915440 & -76 & 297.47 & 221 & $4 / 12 / 2005$ \\
\hline 05S08W30CBA1 & 341446 & 915527 & -83 & 290.93 & 207 & $4 / 13 / 2005$ \\
\hline 05S09W19BAA3 & 341609 & 920131 & -32 & 257.64 & 226 & $4 / 12 / 2005$ \\
\hline 05S09W24DBD1 & 341530 & 915556 & -69 & 277.12 & 208 & $4 / 13 / 2005$ \\
\hline 05S10W16DBD1 & 341635 & 920534 & 18 & 283.89 & 302 & $4 / 12 / 2005$ \\
\hline 06S08W16CCC1 & 341143 & 915517 & -53 & 255.74 & 202 & $4 / 13 / 2005$ \\
\hline 06S08W25ADC1 & 341025 & 915116 & -22 & 225.65 & 203 & $4 / 13 / 2005$ \\
\hline 06S09W17CAD1 & 341159 & 920207 & -25 & 258.15 & 233 & $4 / 13 / 2005$ \\
\hline 06S09W17CCA1 & 341152 & 920221 & -34 & 267.95 & 234 & $4 / 13 / 2005$ \\
\hline 06S10W23ACA2 & 341123 & 920504 & 11 & 223.68 & 235 & $4 / 12 / 2005$ \\
\hline 06S10W23ACD1 & 341116 & 920508 & 15 & 223.97 & 239 & $4 / 12 / 2005$ \\
\hline 06S10W23DBA1 & 341105 & 920506 & 15 & 237.29 & 252 & $4 / 12 / 2005$ \\
\hline 07S07W24BAB1 & 340633 & 914523 & 23 & 164.84 & 188 & $4 / 13 / 2005$ \\
\hline 07S10W24CAC1 & 340549 & 920421 & 6 & 305.17 & 311 & $4 / 13 / 2005$ \\
\hline
\end{tabular}


Appendix 1. Water-level data collected during spring 2005 from wells completed in the Sparta-Memphis aquifer in Arkansas and Louisiana. - Continued

[NGVD of 1929, National Geodetic Vertical Datum of 1929; Horizontal datum is NAD of 1983]

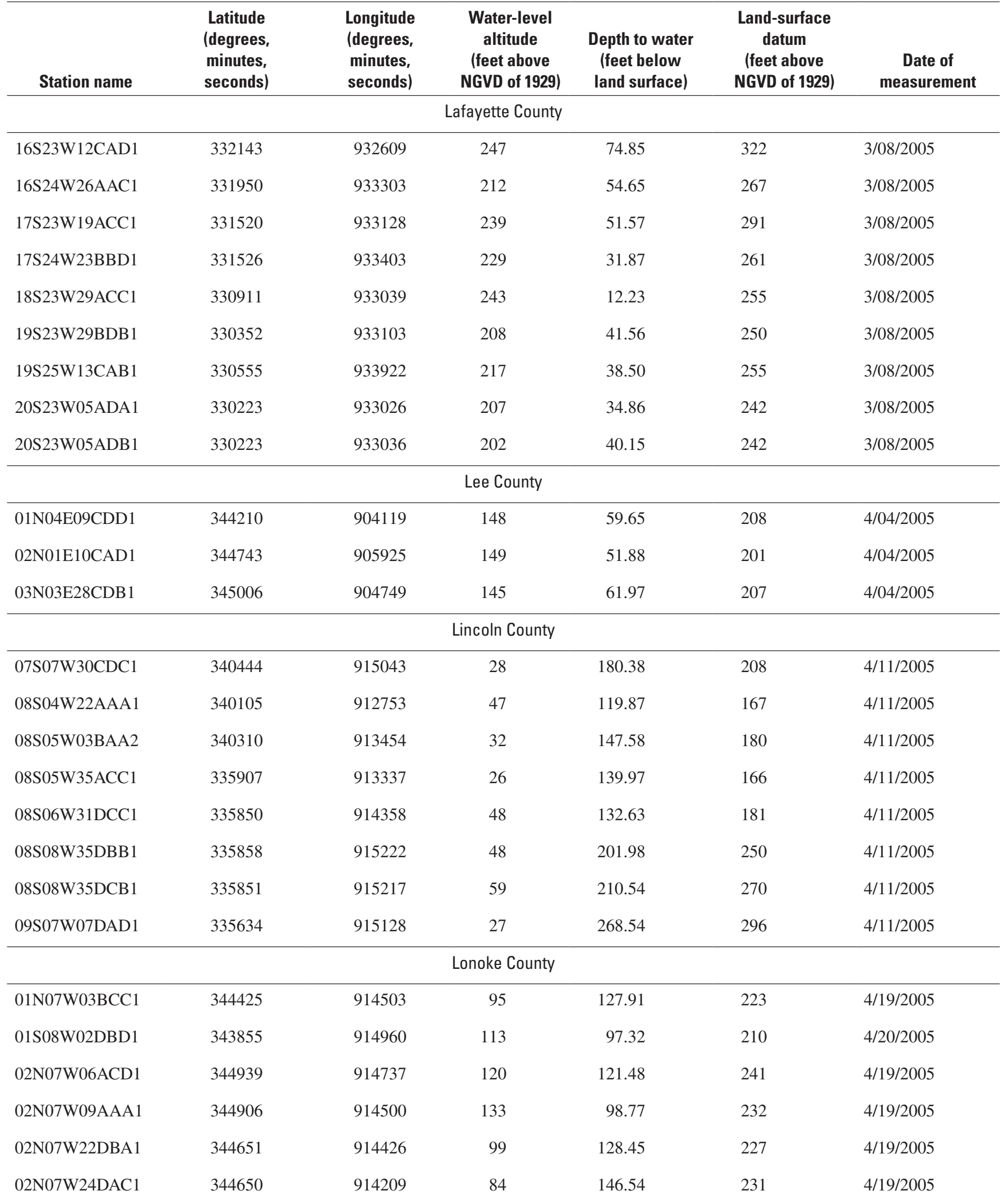


40 Status of Water Levels and Selected Water-Quality Conditions in the Sparta-Memphis Aquifer in Arkansas and the Status of Water Levels in the Sparta Aquifer in Louisiana, Spring 2005

Appendix 1. Water-level data collected during spring 2005 from wells completed in the Sparta-Memphis aquifer in Arkansas and Louisiana. - Continued

[NGVD of 1929, National Geodetic Vertical Datum of 1929; Horizontal datum is NAD of 1983]

\begin{tabular}{|c|c|c|c|c|c|c|}
\hline Station name & $\begin{array}{l}\text { Latitude } \\
\text { (degrees, } \\
\text { minutes, } \\
\text { seconds) }\end{array}$ & $\begin{array}{l}\text { Longitude } \\
\text { (degrees, } \\
\text { minutes, } \\
\text { seconds) }\end{array}$ & $\begin{array}{c}\text { Water-level } \\
\text { altitude } \\
\text { (feet above } \\
\text { NGVD of 1929) }\end{array}$ & $\begin{array}{c}\text { Depth to water } \\
\text { (feet below } \\
\text { land surface) }\end{array}$ & $\begin{array}{c}\text { Land-surface } \\
\text { datum } \\
\text { (feet above } \\
\text { NGVD of 1929) }\end{array}$ & $\begin{array}{c}\text { Date of } \\
\text { measurement }\end{array}$ \\
\hline \multicolumn{7}{|c|}{ Lonoke County_Continued } \\
\hline 02N07W32DDD1 & 344453 & 914619 & 97 & 129.33 & 226 & $4 / 19 / 2005$ \\
\hline 02S07W08DCC1 & 343235 & 914700 & 62 & 140.15 & 202 & $4 / 20 / 2005$ \\
\hline 02S08W16BDA1 & 343228 & 915232 & 96 & 119.77 & 216 & $4 / 20 / 2005$ \\
\hline 02S09W15BBB2 & 343247 & 915825 & 155 & 71.35 & 226 & $4 / 20 / 2005$ \\
\hline 03N07W03CAA1 & 345445 & 914426 & 157 & 78.28 & 235 & $4 / 19 / 2005$ \\
\hline 03N07W23CCC1 & 345144 & 914350 & 143 & 85.33 & 228 & $4 / 19 / 2005$ \\
\hline 03N08W11ACD1 & 345403 & 914935 & 156 & 91.62 & 248 & $5 / 05 / 2005$ \\
\hline 03N08W22DAD1 & 345205 & 915024 & 140 & 92.69 & 233 & $5 / 05 / 2005$ \\
\hline 03N08W22DAD2 & 345205 & 915024 & 136 & 96.57 & 233 & $5 / 05 / 2005$ \\
\hline 03N08W22DDD2 & 345152 & 915025 & 139 & 96.24 & 235 & $5 / 05 / 2005$ \\
\hline \multicolumn{7}{|c|}{ Mississippi County } \\
\hline 11N09E26AAD3 & 353302 & 900523 & 221 & 19.06 & 240 & $4 / 05 / 2005$ \\
\hline 11N09E26ABA2 & 353304 & 900539 & 221 & 15.34 & 236 & $4 / 05 / 2005$ \\
\hline \multicolumn{7}{|c|}{ Monroe County } \\
\hline 01N03W14CCB1 & 344144 & 911801 & 99 & 72.73 & 172 & $3 / 31 / 2005$ \\
\hline 03N01W33CDD1 & 345446 & 910635 & 142 & 68.01 & 210 & $3 / 31 / 2005$ \\
\hline 03N02W26DAB1 & 345042 & 911026 & 145 & 47.13 & 192 & $3 / 31 / 2005$ \\
\hline 04N02W28DDD4 & 345535 & 911221 & 162 & 30.49 & 192 & $3 / 31 / 2005$ \\
\hline 04N02W30BAC1 & 345617 & 911504 & 167 & 14.59 & 182 & $3 / 31 / 2005$ \\
\hline 04N02W30BAD1 & 345617 & 911515 & 166 & 9.86 & 176 & $3 / 31 / 2005$ \\
\hline \multicolumn{7}{|c|}{ Nevada County } \\
\hline 14S21W04CCB1 & 333251 & 931708 & 302 & 58.44 & 360 & $3 / 08 / 2005$ \\
\hline \multicolumn{7}{|c|}{ Ouachita County } \\
\hline 11S15W27ABD1 & 334441 & 923726 & 128 & 71.72 & 200 & $3 / 17 / 2005$ \\
\hline 11S17W14CAC1 & 334631 & 924927 & 127 & 18.70 & 146 & $3 / 17 / 2005$ \\
\hline 11S17W36CCA1 & 334341 & 924834 & 126 & 7.18 & 133 & $3 / 17 / 2005$ \\
\hline 11S18W20AAA1 & 334614 & 925759 & 257 & 44.10 & 301 & $3 / 17 / 2005$ \\
\hline 12S15W09BBA1 & 334223 & 923922 & 142 & 70.57 & 213 & $3 / 17 / 2005$ \\
\hline 12S16W25BDC1 & 333929 & 924211 & 106 & 33.82 & 140 & 3/17/2005 \\
\hline
\end{tabular}


Appendix 1. Water-level data collected during spring 2005 from wells completed in the Sparta-Memphis aquifer in Arkansas and Louisiana. - Continued

[NGVD of 1929, National Geodetic Vertical Datum of 1929; Horizontal datum is NAD of 1983]

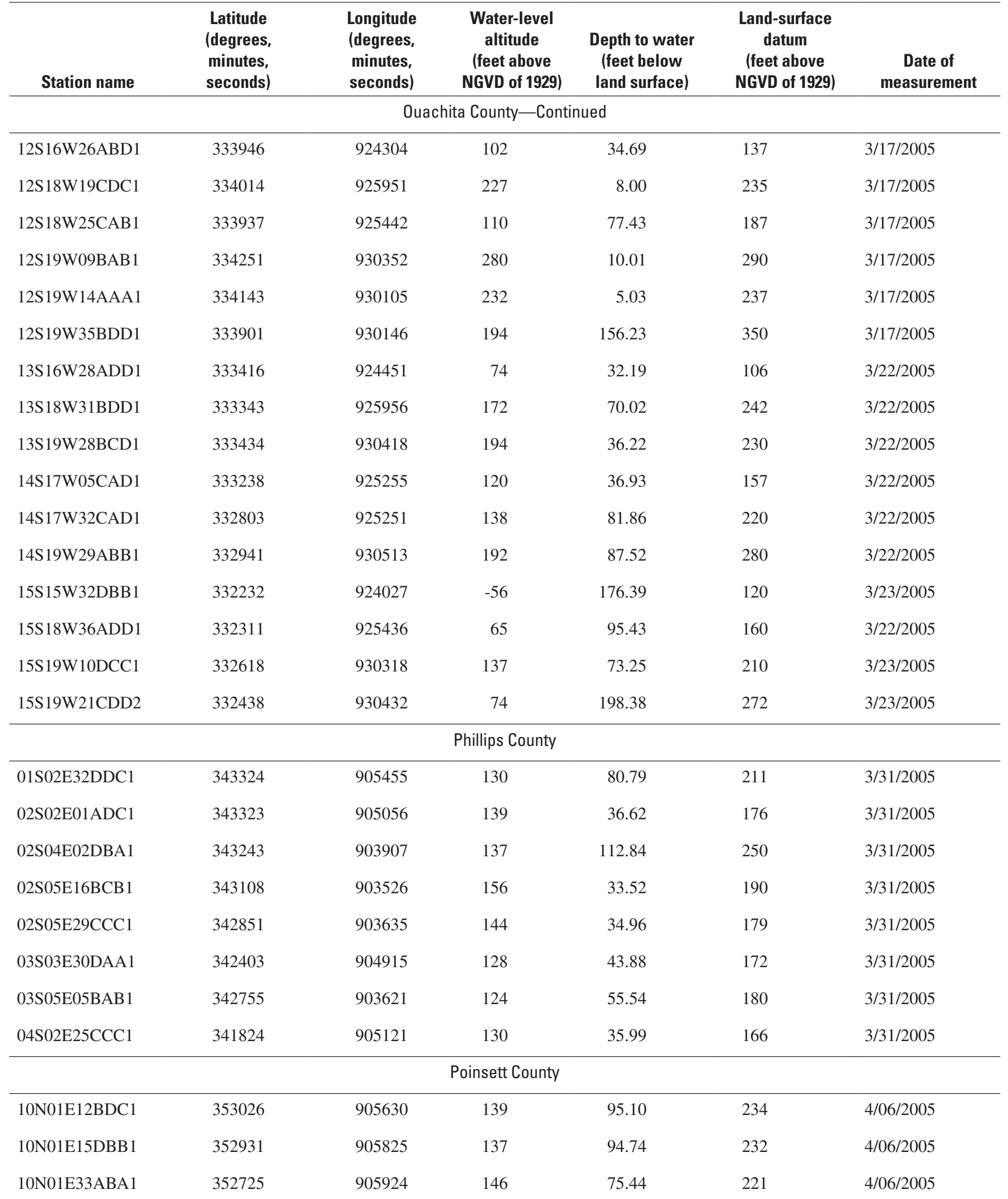


42 Status of Water Levels and Selected Water-Quality Conditions in the Sparta-Memphis Aquifer in Arkansas and the Status of Water Levels in the Sparta Aquifer in Louisiana, Spring 2005

Appendix 1. Water-level data collected during spring 2005 from wells completed in the Sparta-Memphis aquifer in Arkansas and Louisiana. - Continued

[NGVD of 1929, National Geodetic Vertical Datum of 1929; Horizontal datum is NAD of 1983]

\begin{tabular}{|c|c|c|c|c|c|c|}
\hline Station name & $\begin{array}{c}\text { Latitude } \\
\text { (degrees, } \\
\text { minutes, } \\
\text { seconds) }\end{array}$ & $\begin{array}{l}\text { Longitude } \\
\text { (degrees, } \\
\text { minutes, } \\
\text { seconds) }\end{array}$ & $\begin{array}{l}\text { Water-level } \\
\text { altitude } \\
\text { (feet above } \\
\text { NGVD of 1929) }\end{array}$ & $\begin{array}{l}\text { Depth to water } \\
\text { (feet below } \\
\text { land surface) }\end{array}$ & $\begin{array}{c}\text { Land-surface } \\
\text { datum } \\
\text { (feet above } \\
\text { NGVD of 1929) }\end{array}$ & $\begin{array}{c}\text { Date of } \\
\text { measurement }\end{array}$ \\
\hline \multicolumn{7}{|c|}{ Poinsett County-Continued } \\
\hline 10N03E02BCD1 & 353139 & 904447 & 141 & 109.89 & 251 & $4 / 06 / 2005$ \\
\hline 11N02E16CCC1 & 353448 & 905321 & 138 & 105.49 & 243 & $4 / 06 / 2005$ \\
\hline 11N03E25BDD1 & 353325 & 904323 & 148 & 120.71 & 269 & $4 / 06 / 2005$ \\
\hline 12N03E12BBB1 & 354137 & 904340 & 149 & 96.67 & 246 & $4 / 06 / 2005$ \\
\hline 01N05W19CDC1 & 344113 & 913505 & 73 & 139.47 & 212 & $3 / 30 / 2005$ \\
\hline 01N06W02ABB1 & 344442 & 913701 & 105 & 115.65 & 221 & $3 / 30 / 2005$ \\
\hline 01N06W34CBB1 & 343943 & 913846 & 70 & 155.79 & 226 & $3 / 30 / 2005$ \\
\hline 01S05W06BCB1 & 343904 & 913532 & 71 & 148.65 & 220 & $3 / 30 / 2005$ \\
\hline 01S05W20ABB1 & 343640 & 913352 & 61 & 158.85 & 220 & $3 / 30 / 2005$ \\
\hline 01S06W01BDD2 & 343859 & 913613 & 62 & 163.98 & 226 & $3 / 30 / 2005$ \\
\hline 02N06W21DAD1 & 344644 & 913829 & 112 & 119.87 & 232 & $3 / 30 / 2005$ \\
\hline 02N06W22BDD1 & 344654 & 913801 & 114 & 118.96 & 233 & $3 / 30 / 2005$ \\
\hline 03N05W03ADA2 & 345452 & 913043 & 145 & 60.03 & 205 & $3 / 31 / 2005$ \\
\hline 03N05W20CCC1 & 345145 & 913356 & 143 & 70.41 & 213 & $3 / 31 / 2005$ \\
\hline 03N06W20CDD1 & 345140 & 914004 & 141 & 83.79 & 225 & $3 / 30 / 2005$ \\
\hline \multicolumn{7}{|c|}{ St. Francis County } \\
\hline 04N04E18BAB1 & 345743 & 904319 & 157 & 63.28 & 220 & $4 / 04 / 2005$ \\
\hline \multicolumn{7}{|c|}{ Union County } \\
\hline 16S14W15CAB1 & 331944 & 923218 & -67 & 160.88 & 94 & $3 / 15 / 2005$ \\
\hline 16S15W20DAA1 & 331860 & 923958 & -98 & 288.32 & 190 & $3 / 15 / 2005$ \\
\hline 16S15W31ACC1 & 331717 & 924129 & -126 & 294.15 & 168 & $3 / 15 / 2005$ \\
\hline
\end{tabular}


Appendix 1. Water-level data collected during spring 2005 from wells completed in the Sparta-Memphis aquifer in Arkansas and Louisiana. - Continued

[NGVD of 1929, National Geodetic Vertical Datum of 1929; Horizontal datum is NAD of 1983]

\begin{tabular}{|c|c|c|c|c|c|c|}
\hline Station name & $\begin{array}{c}\text { Latitude } \\
\text { (degrees, } \\
\text { minutes, } \\
\text { seconds) }\end{array}$ & $\begin{array}{c}\text { Longitude } \\
\text { (degrees, } \\
\text { minutes, } \\
\text { seconds) }\end{array}$ & $\begin{array}{c}\text { Water-level } \\
\text { altitude } \\
\text { (feet above } \\
\text { NGVD of 1929) }\end{array}$ & $\begin{array}{l}\text { Depth to water } \\
\text { (feet below } \\
\text { land surface) }\end{array}$ & $\begin{array}{c}\text { Land-surface } \\
\text { datum } \\
\text { (feet above } \\
\text { NGVD of 1929) }\end{array}$ & $\begin{array}{c}\text { Date of } \\
\text { measurement }\end{array}$ \\
\hline 16S16W02ABC1 & 332206 & 924329 & -52 & 168.36 & 116 & $2 / 23 / 2005$ \\
\hline 17S12W31DDD1 & 331206 & 922226 & -18 & 238.11 & 220 & $3 / 16 / 2005$ \\
\hline 17S12W32BBC1 & 331202 & 922219 & -20 & 250.58 & 231 & $3 / 16 / 2005$ \\
\hline 17S13W31BAC1 & 331200 & 922916 & -90 & 306.13 & 216 & $3 / 16 / 2005$ \\
\hline 17S15W28DBA1 & 331246 & 923910 & -161 & 390.80 & 230 & $3 / 14 / 2005$ \\
\hline 17S15W28DCC1 & 331233 & 923924 & -152 & 437.19 & 285 & $3 / 17 / 2005$ \\
\hline 17S15W29CDC1 & 331229 & 924039 & -153 & 373.46 & 220 & $3 / 17 / 2005$ \\
\hline 17S15W31DCA1 & 331145 & 924117 & -153 & 425.27 & 272 & $3 / 16 / 2005$ \\
\hline 17S15W31DDA1 & 331144 & 924105 & -154 & 414.99 & 261 & $3 / 14 / 2005$ \\
\hline 17S16W01BAA1 & 331649 & 924233 & -120 & 308.53 & 189 & $3 / 16 / 2005$ \\
\hline 17S17W30DCD1 & 331257 & 925356 & -42 & 321.93 & 280 & $3 / 15 / 2005$ \\
\hline 18S11W09ABC1 & 331012 & 921443 & 38 & 97.38 & 135 & $3 / 16 / 2005$ \\
\hline 18S12W33BBB1 & 330651 & 922120 & -29 & 141.18 & 112 & $3 / 16 / 2005$ \\
\hline 18S14W06CCD1 & 331039 & 923531 & -167 & 398.58 & 232 & $3 / 15 / 2005$ \\
\hline 18S15W03DAB1 & 331104 & 923802 & -134 & 373.72 & 240 & $2 / 23 / 2005$ \\
\hline 18S15W33ADA1 & 330659 & 923858 & -121 & 374.03 & 253 & $3 / 15 / 2005$ \\
\hline 18S15W35DAC1 & 330636 & 923707 & -89 & 290.20 & 201 & $3 / 15 / 2005$ \\
\hline 18S16W10CDD1 & 331000 & 924445 & -146 & 327.54 & 182 & $3 / 16 / 2005$ \\
\hline 18S16W11AAB1 & 331041 & 924314 & -151 & 375.97 & 225 & $3 / 14 / 2005$ \\
\hline 18S16W11DAC1 & 331011 & 924316 & -151 & 422.53 & 272 & $3 / 15 / 2005$ \\
\hline
\end{tabular}


44 Status of Water Levels and Selected Water-Quality Conditions in the Sparta-Memphis Aquifer in Arkansas and the Status of Water Levels in the Sparta Aquifer in Louisiana, Spring 2005

Appendix 1. Water-level data collected during spring 2005 from wells completed in the Sparta-Memphis aquifer in Arkansas and Louisiana. - Continued

[NGVD of 1929, National Geodetic Vertical Datum of 1929; Horizontal datum is NAD of 1983]

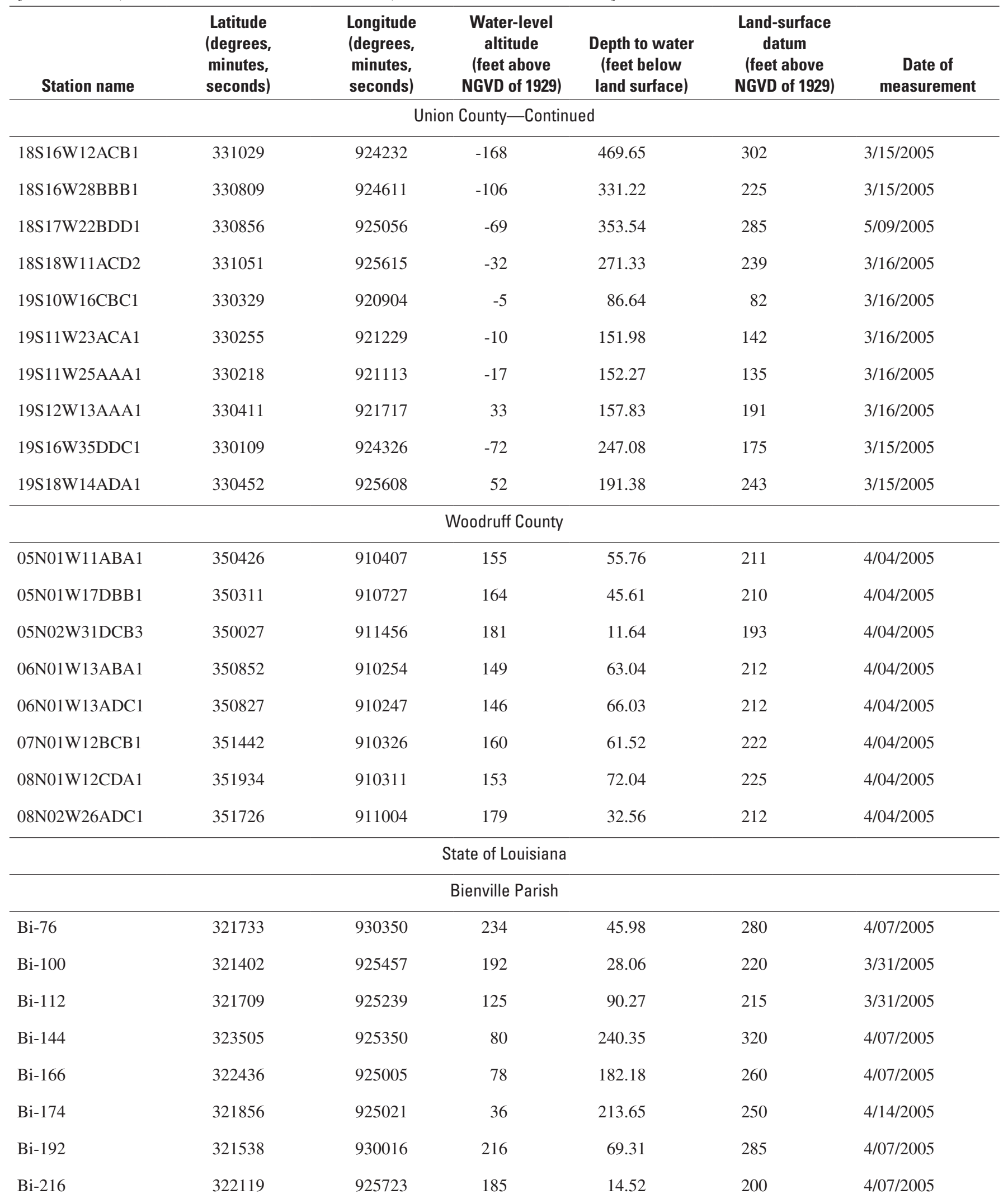


Appendix 1. Water-level data collected during spring 2005 from wells completed in the Sparta-Memphis aquifer in Arkansas and Louisiana. - Continued

[NGVD of 1929, National Geodetic Vertical Datum of 1929; Horizontal datum is NAD of 1983]

\begin{tabular}{|c|c|c|c|c|c|c|}
\hline Station name & $\begin{array}{l}\text { Latitude } \\
\text { (degrees, } \\
\text { minutes, } \\
\text { seconds) }\end{array}$ & $\begin{array}{l}\text { Longitude } \\
\text { (degrees, } \\
\text { minutes, } \\
\text { seconds) }\end{array}$ & $\begin{array}{c}\text { Water-level } \\
\text { altitude } \\
\text { (feet above } \\
\text { NGVD of 1929) }\end{array}$ & $\begin{array}{l}\text { Depth to water } \\
\text { (feet below } \\
\text { land surface) }\end{array}$ & $\begin{array}{c}\text { Land-surface } \\
\text { datum } \\
\text { (feet above } \\
\text { NGVD of 1929) }\end{array}$ & $\begin{array}{c}\text { Date of } \\
\text { measurement }\end{array}$ \\
\hline \multicolumn{7}{|c|}{ Bienville Parish-Continued } \\
\hline $\mathrm{Bi}-284$ & 323241 & 930318 & 148 & 111.28 & 259 & $3 / 30 / 2005$ \\
\hline $\mathrm{Bi}-293$ & 322154 & 925009 & 61 & 178.68 & 240 & $4 / 14 / 2005$ \\
\hline $\mathrm{Bi}-300$ & 321305 & 924842 & 111 & 39.23 & 150 & $4 / 14 / 2005$ \\
\hline \multicolumn{7}{|c|}{ Bossier Parish } \\
\hline \multicolumn{7}{|c|}{ Caldwell Parish } \\
\hline $\mathrm{Ca}-27$ & 321045 & 920607 & 24 & 36.05 & 60 & $4 / 05 / 2005$ \\
\hline $\mathrm{Ca}-51$ & 321430 & 921228 & 8 & 172.32 & 180 & $4 / 05 / 2005$ \\
\hline $\mathrm{Ca}-86 \mathrm{~B}$ & 320154 & 921646 & 77 & 82.94 & 160 & $4 / 01 / 2005$ \\
\hline Ca-106 & 321507 & 921452 & -12 & 232.37 & 220 & $3 / 10 / 2005$ \\
\hline \multicolumn{7}{|c|}{ Claiborne Parish } \\
\hline Cl-148 & 325437 & 925033 & -9 & 199.03 & 190 & $3 / 10 / 2005$ \\
\hline Cl-149 & 330003 & 924500 & -63 & 292.55 & 230 & $2 / 23 / 2005$ \\
\hline Cl-149 & 330002 & 924459 & -62 & 292.36 & 230 & $3 / 10 / 2005$ \\
\hline $\mathrm{Cl}-150$ & 325103 & 924349 & -33 & 257.86 & 225 & $3 / 08 / 2005$ \\
\hline Cl-180 & 324243 & 925620 & 68 & 291.97 & 360 & $3 / 10 / 2005$ \\
\hline Cl-190 & 325414 & 930133 & 68 & 240.94 & 309 & $3 / 23 / 2005$ \\
\hline $\mathrm{Cl}-215$ & 324034 & 930935 & 188 & 252.26 & 440 & $3 / 02 / 2005$ \\
\hline $\mathrm{Cl}-224$ & 325122 & 930242 & 80 & 160.00 & 240 & $3 / 30 / 2005$ \\
\hline \multicolumn{7}{|c|}{ Jackson Parish } \\
\hline $\mathrm{Ja}-44$ & 321446 & 924317 & -3 & 172.99 & 170 & $4 / 14 / 2005$ \\
\hline
\end{tabular}


46 Status of Water Levels and Selected Water-Quality Conditions in the Sparta-Memphis Aquifer in Arkansas and the Status of Water Levels in the Sparta Aquifer in Louisiana, Spring 2005

Appendix 1. Water-level data collected during spring 2005 from wells completed in the Sparta-Memphis aquifer in Arkansas and Louisiana. -Continued

[NGVD of 1929, National Geodetic Vertical Datum of 1929; Horizontal datum is NAD of 1983]

\begin{tabular}{|c|c|c|c|c|c|c|}
\hline Station name & $\begin{array}{l}\text { Latitude } \\
\text { (degrees, } \\
\text { minutes, } \\
\text { seconds) }\end{array}$ & $\begin{array}{c}\text { Longitude } \\
\text { (degrees, } \\
\text { minutes, } \\
\text { seconds) }\end{array}$ & $\begin{array}{l}\text { Water-level } \\
\text { altitude } \\
\text { (feet above } \\
\text { NGVD of 1929) }\end{array}$ & $\begin{array}{l}\text { Depth to water } \\
\text { (feet below } \\
\text { land surface) }\end{array}$ & $\begin{array}{c}\text { Land-surface } \\
\text { datum } \\
\text { (feet above } \\
\text { NGVD of 1929) }\end{array}$ & $\begin{array}{c}\text { Date of } \\
\text { measurement }\end{array}$ \\
\hline \multicolumn{7}{|c|}{ Jackson Parish—Continued } \\
\hline Ja-49 & 321709 & 924524 & -8 & 167.61 & 160 & $4 / 01 / 2005$ \\
\hline Ja-115 & 321822 & 922704 & -20 & 200.48 & 180.3 & $4 / 15 / 2005$ \\
\hline Ja-147 & 322357 & 923417 & -34 & 254.48 & 220 & $4 / 01 / 2005$ \\
\hline Ja-148 & 321338 & 923458 & 15 & 230.18 & 245 & $4 / 01 / 2005$ \\
\hline Ja-166 & 321459 & 922329 & 3 & 216.72 & 220 & $4 / 15 / 2005$ \\
\hline \multicolumn{7}{|c|}{ Lincoln Parish } \\
\hline L-1 & 323144 & 923803 & -86 & 386.11 & 300 & $3 / 11 / 2005$ \\
\hline L-26 & 324141 & 923905 & -36 & 190.92 & 155 & $4 / 04 / 2005$ \\
\hline L-30 & 323105 & 923748 & -65 & 394.56 & 330 & $3 / 11 / 2005$ \\
\hline L-32 & 323138 & 923652 & -73 & 352.56 & 280 & $3 / 11 / 2005$ \\
\hline L-117 & 324202 & 923226 & -67 & 153.19 & 86 & $3 / 17 / 2005$ \\
\hline L-137 & 323319 & 923920 & -67 & 306.73 & 240 & $3 / 16 / 2005$ \\
\hline L-138 & 323802 & 923459 & -71 & 231.27 & 160 & $4 / 13 / 2005$ \\
\hline L-152 & 322900 & 924041 & -36 & 325.44 & 289.4 & $4 / 06 / 2005$ \\
\hline L-160 & 322951 & 923823 & -46 & 345.81 & 300 & $3 / 04 / 2005$ \\
\hline L-178 & 323214 & 924648 & 31 & 304.38 & 335 & $3 / 29 / 2005$ \\
\hline L-219 & 322917 & 924336 & -34 & 333.90 & 300 & $4 / 06 / 2005$ \\
\hline \multicolumn{7}{|c|}{ Morehouse Parish } \\
\hline Mo-5 & 324626 & 915439 & -46 & 163.52 & 117.44 & $4 / 05 / 2005$ \\
\hline Mo-86 & 324636 & 914734 & -13 & 107.69 & 95 & $3 / 09 / 2005$ \\
\hline Mo-347 & 324352 & 915310 & -35 & 177.26 & 142.27 & $3 / 17 / 2005$ \\
\hline
\end{tabular}


Appendix 1. Water-level data collected during spring 2005 from wells completed in the Sparta-Memphis aquifer in Arkansas and Louisiana. - Continued

[NGVD of 1929, National Geodetic Vertical Datum of 1929; Horizontal datum is NAD of 1983]

\begin{tabular}{|c|c|c|c|c|c|c|}
\hline Station name & $\begin{array}{c}\text { Latitude } \\
\text { (degrees, } \\
\text { minutes, } \\
\text { seconds) }\end{array}$ & $\begin{array}{c}\text { Longitude } \\
\text { (degrees, } \\
\text { minutes, } \\
\text { seconds) }\end{array}$ & $\begin{array}{c}\text { Water-level } \\
\text { altitude } \\
\text { (feet above } \\
\text { NGVD of 1929) }\end{array}$ & $\begin{array}{l}\text { Depth to water } \\
\text { (feet below } \\
\text { land surface) }\end{array}$ & $\begin{array}{c}\text { Land-surface } \\
\text { datum } \\
\text { (feet above } \\
\text { NGVD of 1929) }\end{array}$ & $\begin{array}{c}\text { Date of } \\
\text { measurement }\end{array}$ \\
\hline \multicolumn{7}{|c|}{ Morehouse Parish-Continued } \\
\hline Mo-350 & 325707 & 915747 & -3 & 114.61 & 112.08 & $3 / 17 / 2005$ \\
\hline \multicolumn{7}{|c|}{ Natchitoches Parish } \\
\hline $\mathrm{Na}-512$ & 320607 & 925944 & 222 & 18.41 & 240 & $4 / 11 / 2005$ \\
\hline $\mathrm{Na}-519$ & 320608 & 925946 & 224 & 16.14 & 240 & $4 / 11 / 2005$ \\
\hline Ou-80 & 322843 & 920844 & -226 & 285.71 & 60 & $4 / 05 / 2005$ \\
\hline Ou-163 & 323155 & 920211 & -61 & 140.95 & 80 & $4 / 18 / 2005$ \\
\hline Ou-401A & 322422 & 920207 & -50 & 112.47 & 62.28 & $3 / 03 / 2005$ \\
\hline $\mathrm{Ou}-402$ & 321714 & 920414 & 2 & 61.47 & 63.3 & $3 / 03 / 2005$ \\
\hline Ou-404 & 323030 & 915548 & -28 & 88.76 & 60.89 & $3 / 03 / 2005$ \\
\hline Ou-444 & 323100 & 921658 & -120 & 237.77 & 118 & $4 / 06 / 2005$ \\
\hline Ou-580 & 321929 & 921330 & -51 & 266.02 & 215 & $4 / 19 / 2005$ \\
\hline \multicolumn{7}{|c|}{ Sabine Parish } \\
\hline Sa-389 & 312314 & 933529 & 181 & 78.72 & 260 & $4 / 26 / 2005$ \\
\hline \multicolumn{7}{|c|}{ Union Parish } \\
\hline Un-26 & 324417 & 920900 & -62 & 195.89 & 133.92 & $4 / 05 / 2005$ \\
\hline Un-79 & 324955 & 920840 & -47 & 165.11 & 118 & $3 / 31 / 2005$ \\
\hline Un-83 & 325550 & 923916 & -49 & 171.17 & 122 & $4 / 04 / 2005$ \\
\hline Un-84 & 325647 & 922415 & -53 & 262.64 & 210 & $4 / 05 / 2005$ \\
\hline Un-85 & 325938 & 922039 & 25 & 234.99 & 260 & $3 / 17 / 2005$ \\
\hline Un-86 & 325929 & 921140 & -22 & 111.58 & 90 & $3 / 17 / 2005$ \\
\hline Un-134 & 323655 & 922117 & -105 & 324.62 & 220 & $3 / 17 / 2005$ \\
\hline
\end{tabular}


48 Status of Water Levels and Selected Water-Quality Conditions in the Sparta-Memphis Aquifer in Arkansas and the Status of Water Levels in the Sparta Aquifer in Louisiana, Spring 2005

Appendix 1. Water-level data collected during spring 2005 from wells completed in the Sparta-Memphis aquifer in Arkansas and Louisiana. - Continued

[NGVD of 1929, National Geodetic Vertical Datum of 1929; Horizontal datum is NAD of 1983]

\begin{tabular}{|c|c|c|c|c|c|c|}
\hline Station name & $\begin{array}{c}\text { Latitude } \\
\text { (degrees, } \\
\text { minutes, } \\
\text { seconds) }\end{array}$ & $\begin{array}{c}\text { Longitude } \\
\text { (degrees, } \\
\text { minutes, } \\
\text { seconds) }\end{array}$ & $\begin{array}{c}\text { Water-level } \\
\text { altitude } \\
\text { (feet above } \\
\text { NGVD of 1929) }\end{array}$ & $\begin{array}{l}\text { Depth to water } \\
\text { (feet below } \\
\text { land surface) }\end{array}$ & $\begin{array}{c}\text { Land-surface } \\
\text { datum } \\
\text { (feet above } \\
\text { NGVD of 1929) }\end{array}$ & $\begin{array}{c}\text { Date of } \\
\text { measurement }\end{array}$ \\
\hline \multicolumn{7}{|c|}{ Union Parish-Continued } \\
\hline Un-135 & 324056 & 921212 & -91 & 250.68 & 160 & $4 / 20 / 2005$ \\
\hline Un-138 & 324707 & 922925 & -85 & 304.88 & 220 & $3 / 29 / 2005$ \\
\hline Un-155 & 324850 & 922138 & -90 & 290.20 & 200 & $3 / 30 / 2005$ \\
\hline Un-157 & 324708 & 922310 & -79 & 259.13 & 180 & $3 / 29 / 2005$ \\
\hline \multicolumn{7}{|c|}{ Webster Parish } \\
\hline Wb-219 & 323220 & 931659 & 184 & 5.90 & 190 & $3 / 02 / 2005$ \\
\hline Wb-241 & 325938 & 932753 & 179 & 50.60 & 230 & $3 / 23 / 2005$ \\
\hline Wb-271 & 323221 & 931404 & 195 & 82.73 & 278 & $3 / 15 / 2005$ \\
\hline Wb-285 & 323553 & 931411 & 175 & 165.20 & 340 & $3 / 02 / 2005$ \\
\hline Wb-326 & 325200 & 931517 & 148 & 111.98 & 260 & $3 / 01 / 2005$ \\
\hline Wb-355 & 330008 & 932643 & 172 & 72.51 & 245 & $3 / 23 / 2005$ \\
\hline Wb-399 & 325518 & 932219 & 163 & 41.93 & 205 & $4 / 04 / 2005$ \\
\hline Wb-419 & 324021 & 931916 & 157 & 73.31 & 230 & $3 / 04 / 2005$ \\
\hline $\mathrm{Wb}-423$ & 324823 & 931653 & 124 & 276.46 & 400 & $3 / 14 / 2005$ \\
\hline Wb-424 & 322912 & 931103 & 223 & 56.82 & 280 & $3 / 02 / 2005$ \\
\hline Wb-467 & 323540 & 932132 & 174 & 36.05 & 210 & $3 / 04 / 2005$ \\
\hline Wb-475 & 323533 & 932003 & 158 & 14.67 & 173 & $3 / 01 / 2005$ \\
\hline Wb-481 & 324920 & 932505 & 156 & 70.62 & 227 & $3 / 15 / 2005$ \\
\hline Wb-490 & 324118 & 931439 & 153 & 228.49 & 381 & $3 / 04 / 2005$ \\
\hline Wb-6289Z & 323408 & 932211 & 144 & 51.39 & 195 & $3 / 24 / 2005$ \\
\hline
\end{tabular}


Appendix 1. Water-level data collected during spring 2005 from wells completed in the Sparta-Memphis aquifer in Arkansas and Louisiana. - Continued

[NGVD of 1929, National Geodetic Vertical Datum of 1929; Horizontal datum is NAD of 1983]

\begin{tabular}{lcccccc}
\hline Station name & $\begin{array}{c}\text { Latitude } \\
\text { (degrees, } \\
\text { minutes, } \\
\text { seconds) }\end{array}$ & $\begin{array}{c}\text { Longitude } \\
\text { (degrees, } \\
\text { minutes, } \\
\text { seconds) }\end{array}$ & $\begin{array}{c}\text { Water-level } \\
\text { altitude } \\
\text { (feet above } \\
\text { NGVD of 1929) }\end{array}$ & $\begin{array}{c}\text { Lepth to water } \\
\text { (feet below } \\
\text { land surface) }\end{array}$ & $\begin{array}{c}\text { Land-surface } \\
\text { datum } \\
\text { (feet above } \\
\text { NGVD of 1929) }\end{array}$ & $\begin{array}{c}\text { Date of } \\
\text { measurement }\end{array}$ \\
\hline W-28 & \multicolumn{5}{c}{ Winn Parish } \\
W-144B & 315527 & 923708 & 42 & 63.35 & 105 & $4 / 01 / 2005$ \\
W-156 & 315450 & 923101 & 83 & 56.53 & 140 & $3 / 07 / 2005$ \\
W-161 & 320619 & 923416 & 41 & 216.36 & 257 & $4 / 08 / 2005$ \\
W-172 & 315646 & 923520 & 50 & 109.83 & 160 & $4 / 13 / 2005$ \\
W-179 & 320541 & 922916 & 40 & 100.48 & 140 & $4 / 01 / 2005$ \\
W-212 & 315948 & 923003 & 71 & 123.81 & 195 & $3 / 07 / 2005$ \\
W-223 & 320444 & 923849 & 48 & 221.80 & 270 & $4 / 08 / 2005$ \\
\hline
\end{tabular}


50 Status of Water Levels and Selected Water-Quality Conditions in the Sparta-Memphis Aquifer in Arkansas and the Status of Water Levels in the Sparta Aquifer in Louisiana, Spring 2005

Appendix 2. Difference in water level from 2001 to 2005 in the Sparta-Memphis aquifer in Arkansas and Louisiana.

[Horizontal datum is NAD of 1983; negative values denote a decline; 2001 depth to water level (Schrader, 2004)]

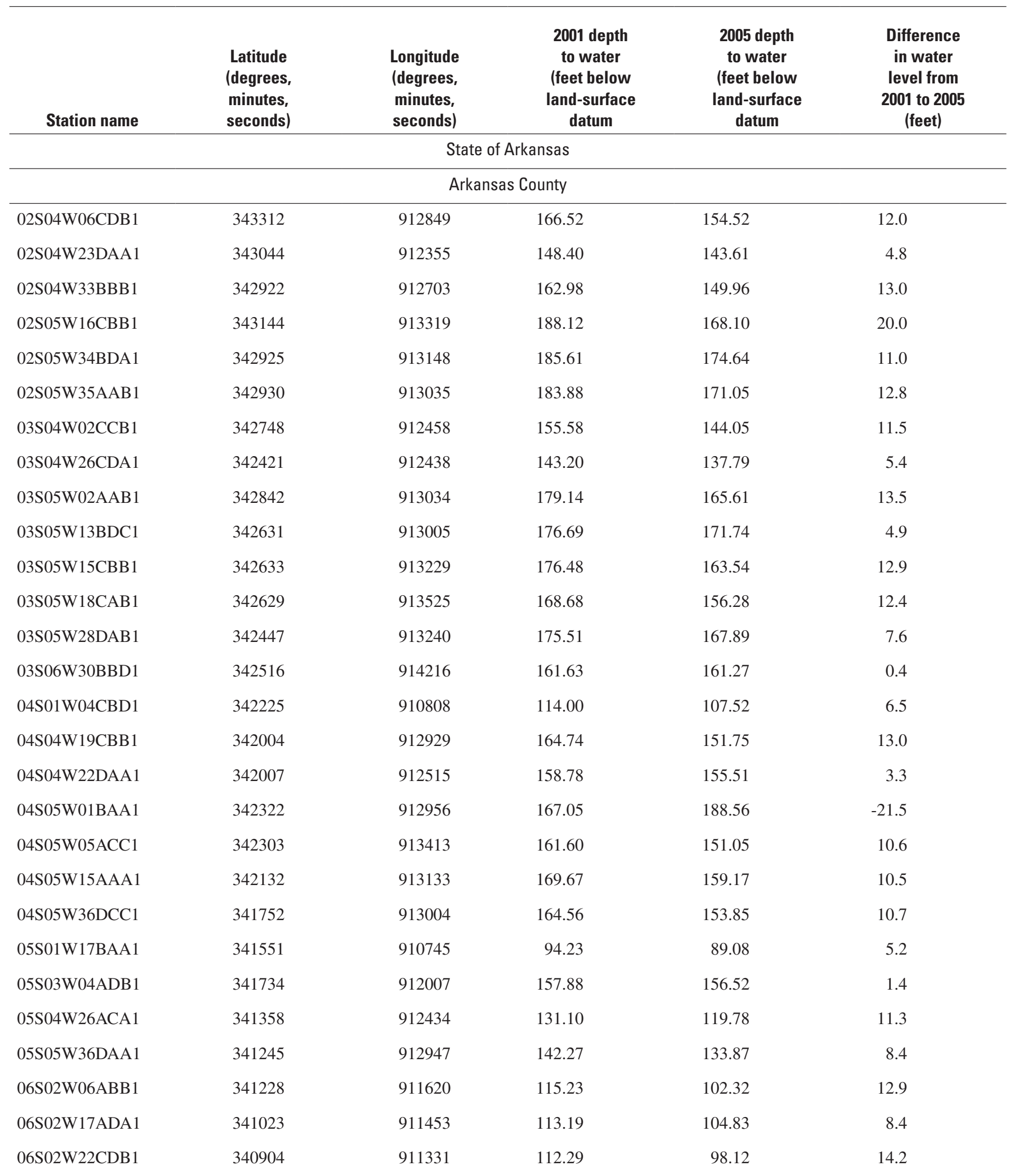


Appendix 2. Difference in water level from 2001 to 2005 in the Sparta-Memphis aquifer in Arkansas and Louisiana. —Continued

[Horizontal datum is NAD of 1983; negative values denote a decline; 2001 depth to water level (Schrader, 2004)]

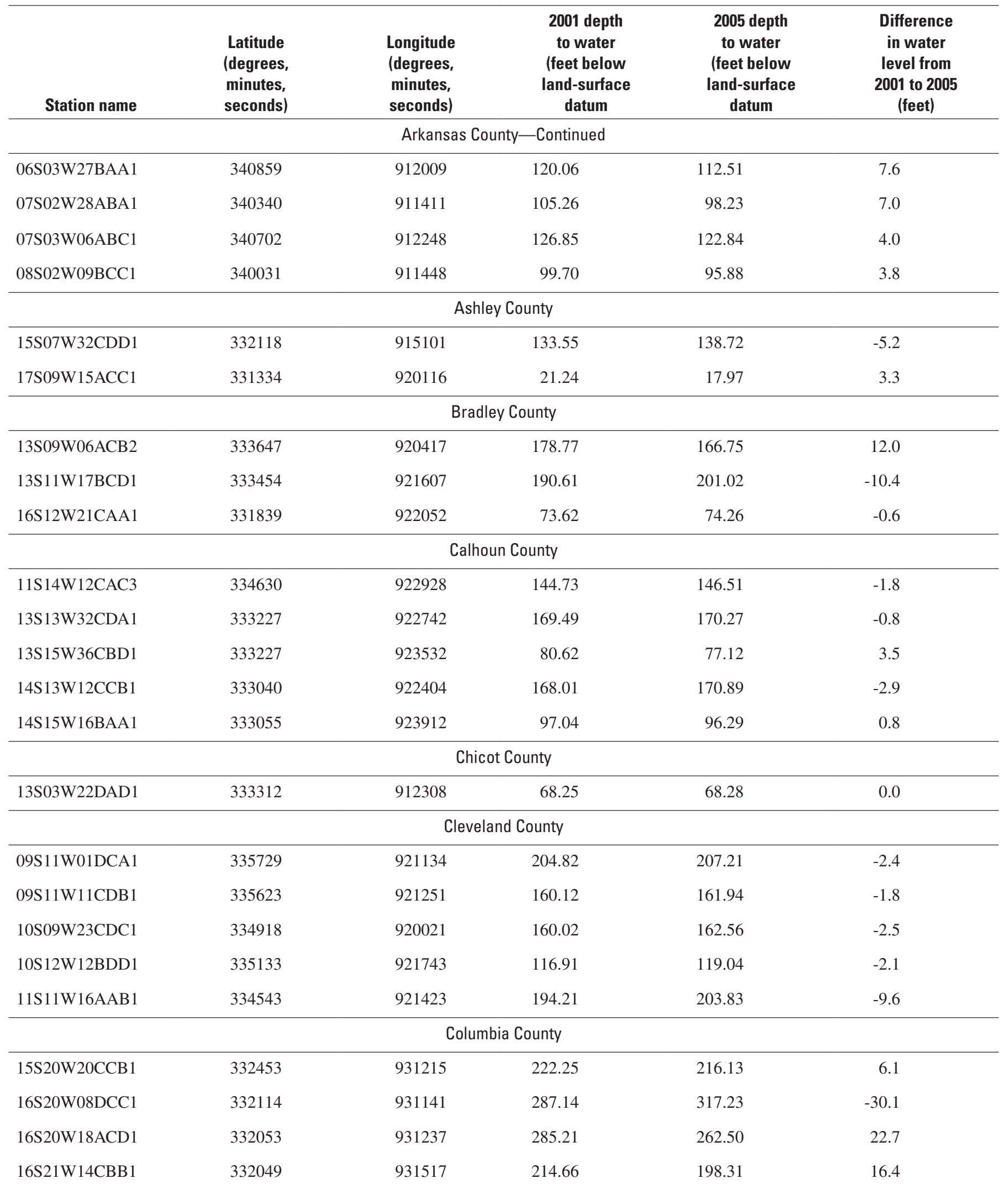


52 Status of Water Levels and Selected Water-Quality Conditions in the Sparta-Memphis Aquifer in Arkansas and the Status of Water Levels in the Sparta Aquifer in Louisiana, Spring 2005

Appendix 2. Difference in water level from 2001 to 2005 in the Sparta-Memphis aquifer in Arkansas and Louisiana. —Continued

[Horizontal datum is NAD of 1983; negative values denote a decline; 2001 depth to water level (Schrader, 2004)]

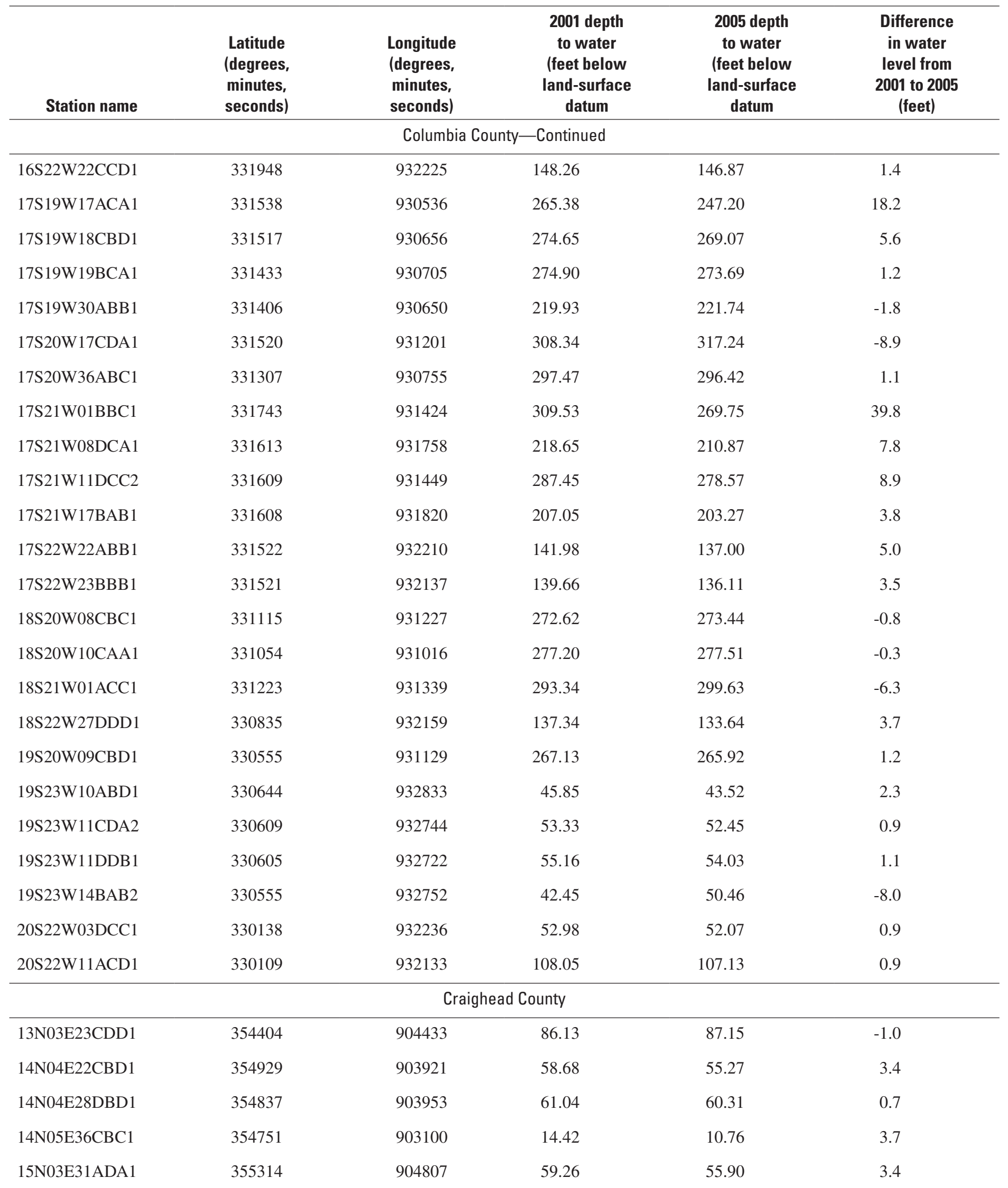


Appendix 2. Difference in water level from 2001 to 2005 in the Sparta-Memphis aquifer in Arkansas and Louisiana. —Continued

[Horizontal datum is NAD of 1983; negative values denote a decline; 2001 depth to water level (Schrader, 2004)]

\begin{tabular}{|c|c|c|c|c|c|}
\hline Station name & $\begin{array}{c}\text { Latitude } \\
\text { (degrees, } \\
\text { minutes, } \\
\text { seconds) }\end{array}$ & $\begin{array}{l}\text { Longitude } \\
\text { (degrees, } \\
\text { minutes, } \\
\text { seconds) }\end{array}$ & $\begin{array}{c}2001 \text { depth } \\
\text { to water } \\
\text { (feet below } \\
\text { land-surface } \\
\text { datum }\end{array}$ & $\begin{array}{l}2005 \text { depth } \\
\text { to water } \\
\text { (feet below } \\
\text { land-surface } \\
\text { datum }\end{array}$ & $\begin{array}{c}\text { Difference } \\
\text { in water } \\
\text { level from } \\
2001 \text { to } 2005 \\
\text { (feet) }\end{array}$ \\
\hline \multicolumn{6}{|c|}{ Craighead County-Continued } \\
\hline 15N04E20ADB1 & 355506 & 904043 & 120.71 & 118.18 & 2.5 \\
\hline 15N06E18ACA1 & 355544 & 902858 & 19.48 & 15.31 & 4.2 \\
\hline \multicolumn{6}{|c|}{ Crittenden County } \\
\hline 05N08E11CCA2 & 350345 & 901300 & 28.56 & 22.94 & 5.6 \\
\hline 06N09E23AAB1 & 350745 & 900553 & 60.98 & 61.57 & -0.6 \\
\hline \multicolumn{6}{|c|}{ Cross County } \\
\hline 06N04E06ACA1 & 351004 & 904238 & 202.82 & 201.92 & 0.9 \\
\hline 07N05E04ADD1 & 351538 & 903330 & 33.43 & 36.08 & -2.7 \\
\hline 09N01E16CAC1 & 352405 & 905951 & 77.76 & 81.37 & -3.6 \\
\hline 09N03E22AAB2 & 352404 & 904518 & 124.71 & 126.92 & -2.2 \\
\hline 09N03E22AAD1 & 352403 & 904512 & 127.62 & 130.19 & -2.6 \\
\hline 08S15W34BDC1 & 335859 & 923730 & 25.52 & 25.63 & -0.1 \\
\hline 08S16W18ACC1 & 340152 & 924639 & 15.16 & 16.03 & -0.9 \\
\hline 08S16W27DDD1 & 335937 & 924307 & 33.19 & 32.77 & 0.4 \\
\hline 09S13W35CCD1 & 335309 & 922413 & 70.59 & 71.36 & -0.8 \\
\hline 09S14W01BDC1 & 335754 & 922919 & 78.31 & 78.66 & -0.3 \\
\hline 09S16W19CAA1 & 335605 & 924701 & 5.61 & 6.03 & -0.4 \\
\hline 10S13W34ACA2 & 334829 & 922458 & 149.50 & 151.47 & -2.0 \\
\hline 10S15W18BCC 1 & 335120 & 924120 & 77.56 & 75.78 & 1.8 \\
\hline \multicolumn{6}{|c|}{ Desha County } \\
\hline 09S02W26AAC1 & 335346 & 911521 & 71.32 & 68.91 & 2.4 \\
\hline 09S04W28DDD1 & 335310 & 913007 & 115.73 & 112.54 & 3.2 \\
\hline
\end{tabular}


54 Status of Water Levels and Selected Water-Quality Conditions in the Sparta-Memphis Aquifer in Arkansas and the Status of Water Levels in the Sparta Aquifer in Louisiana, Spring 2005

Appendix 2. Difference in water level from 2001 to 2005 in the Sparta-Memphis aquifer in Arkansas and Louisiana. —Continued

[Horizontal datum is NAD of 1983; negative values denote a decline; 2001 depth to water level (Schrader, 2004)]

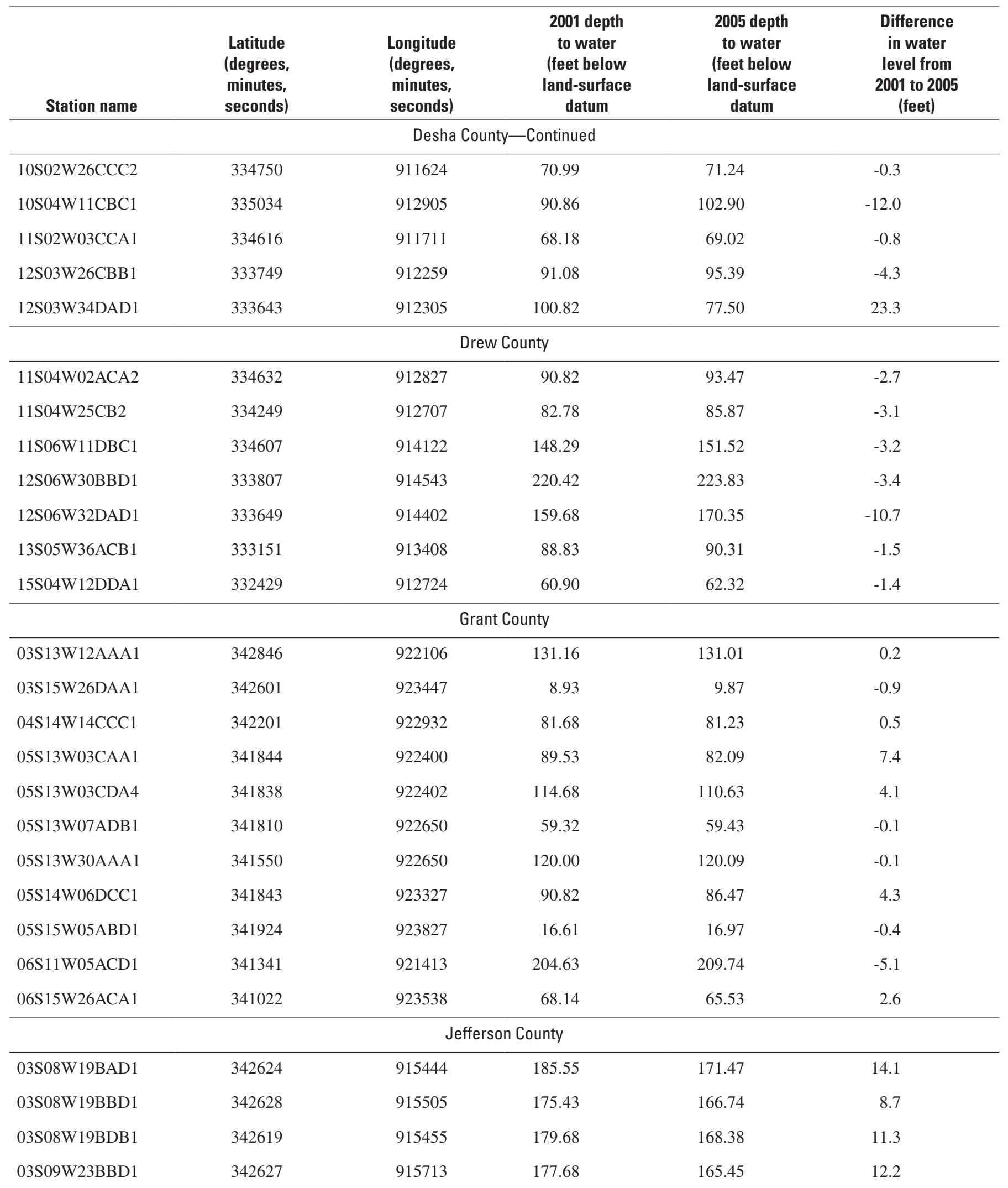


Appendix 2. Difference in water level from 2001 to 2005 in the Sparta-Memphis aquifer in Arkansas and Louisiana. —Continued

[Horizontal datum is NAD of 1983; negative values denote a decline; 2001 depth to water level (Schrader, 2004)]

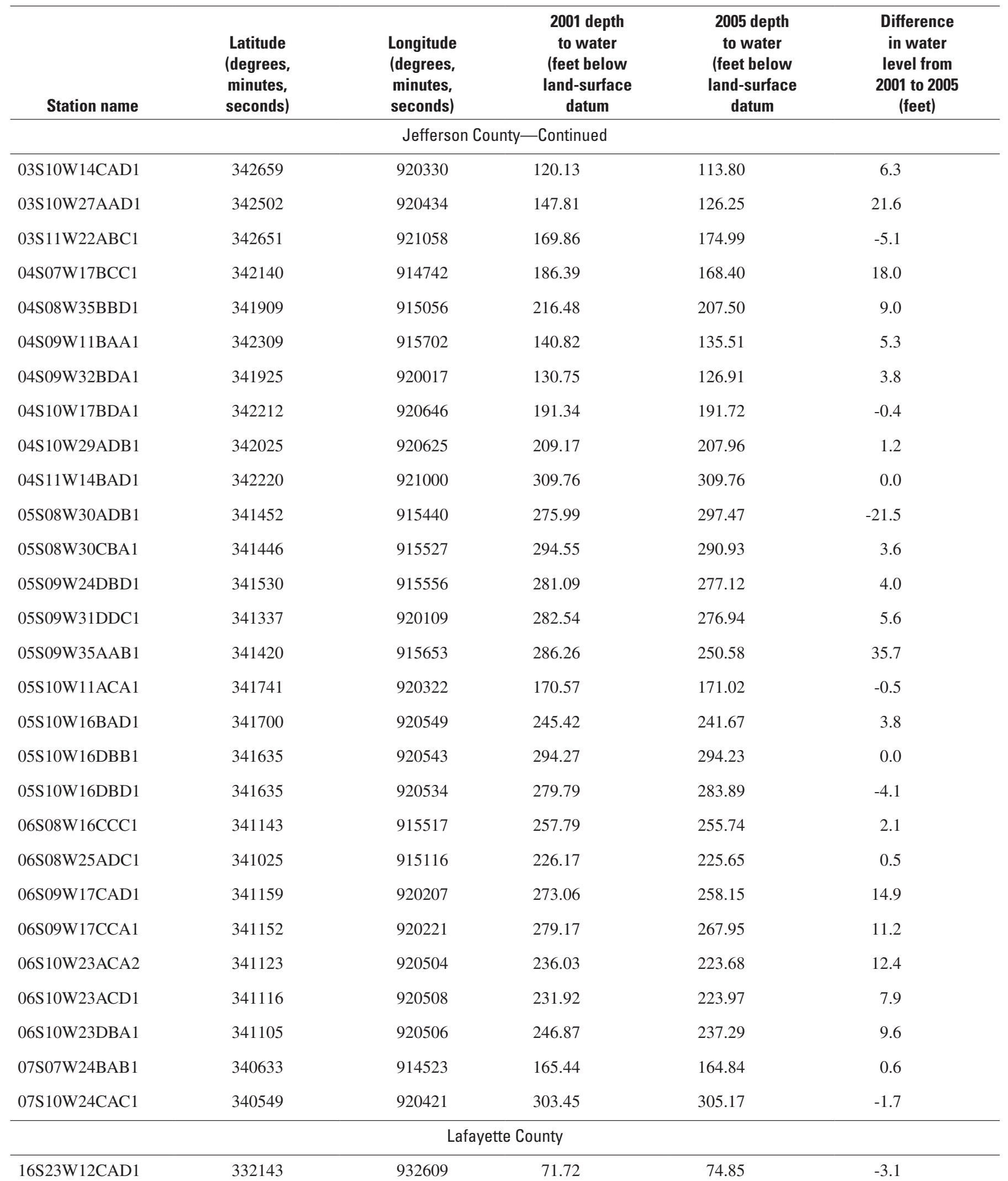


56 Status of Water Levels and Selected Water-Quality Conditions in the Sparta-Memphis Aquifer in Arkansas and the Status of Water Levels in the Sparta Aquifer in Louisiana, Spring 2005

Appendix 2. Difference in water level from 2001 to 2005 in the Sparta-Memphis aquifer in Arkansas and Louisiana. —Continued

[Horizontal datum is NAD of 1983; negative values denote a decline; 2001 depth to water level (Schrader, 2004)]

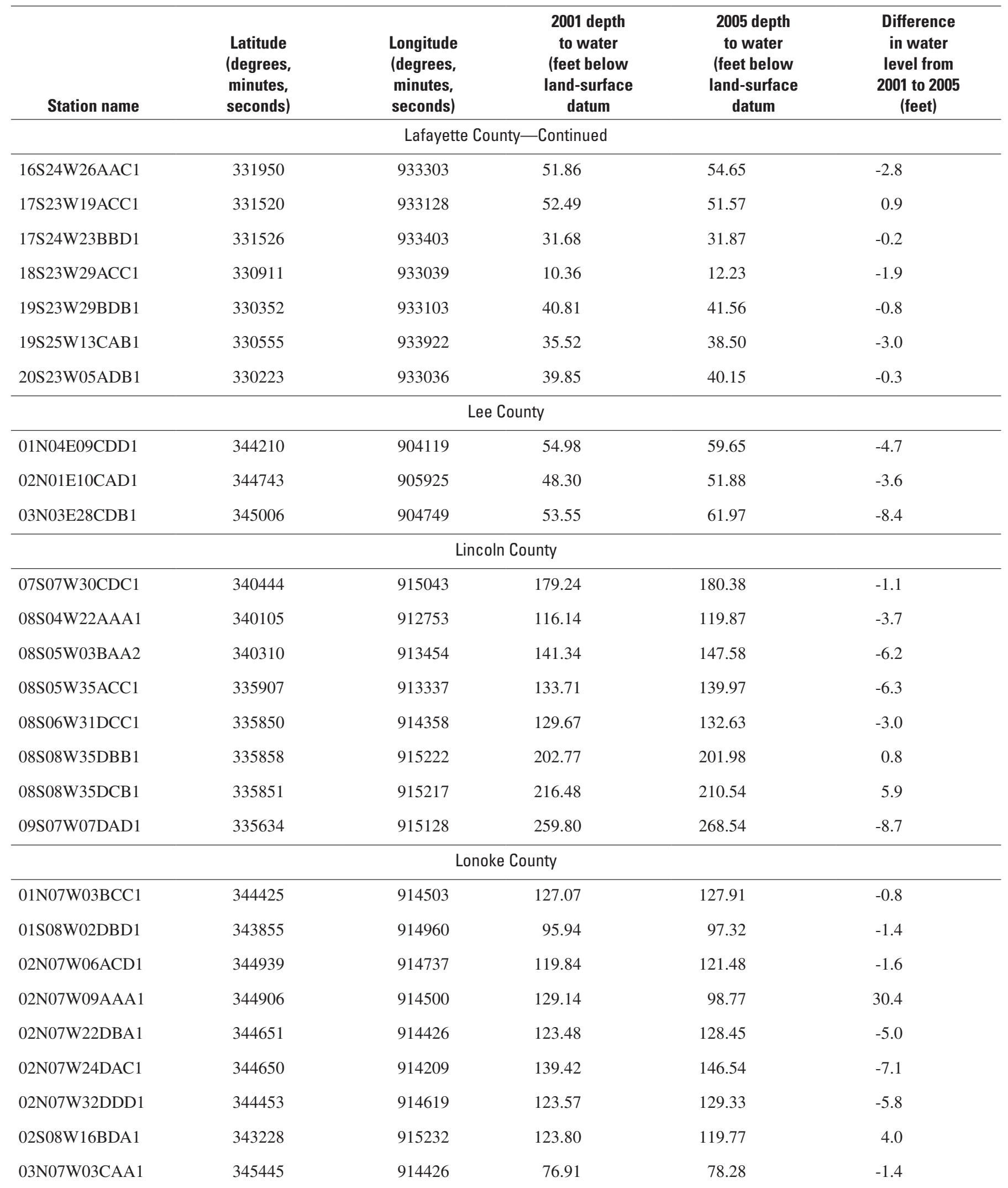


Appendix 2. Difference in water level from 2001 to 2005 in the Sparta-Memphis aquifer in Arkansas and Louisiana. —Continued

[Horizontal datum is NAD of 1983; negative values denote a decline; 2001 depth to water level (Schrader, 2004)]

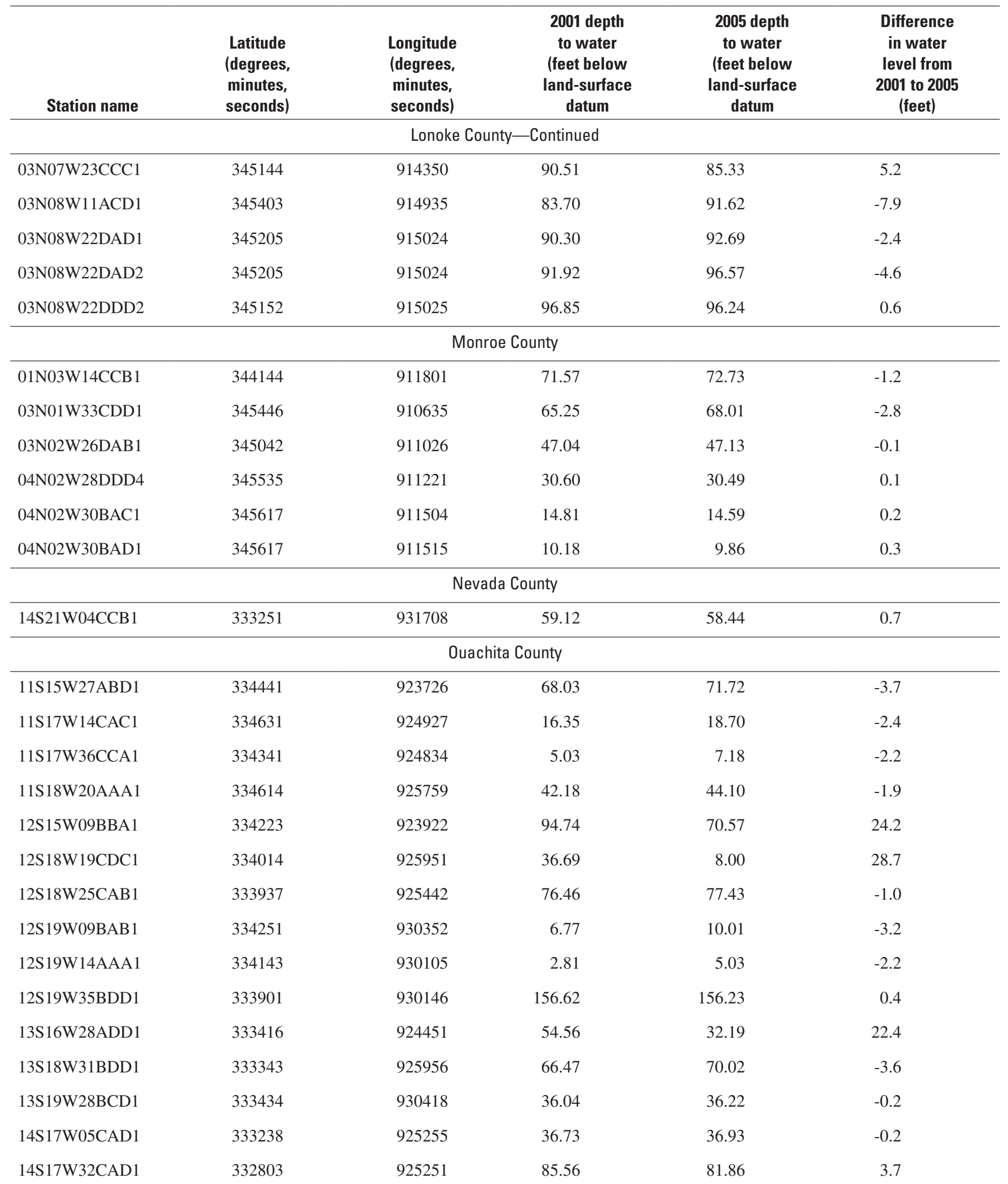


58 Status of Water Levels and Selected Water-Quality Conditions in the Sparta-Memphis Aquifer in Arkansas and the Status of Water Levels in the Sparta Aquifer in Louisiana, Spring 2005

Appendix 2. Difference in water level from 2001 to 2005 in the Sparta-Memphis aquifer in Arkansas and Louisiana. —Continued

[Horizontal datum is NAD of 1983; negative values denote a decline; 2001 depth to water level (Schrader, 2004)]

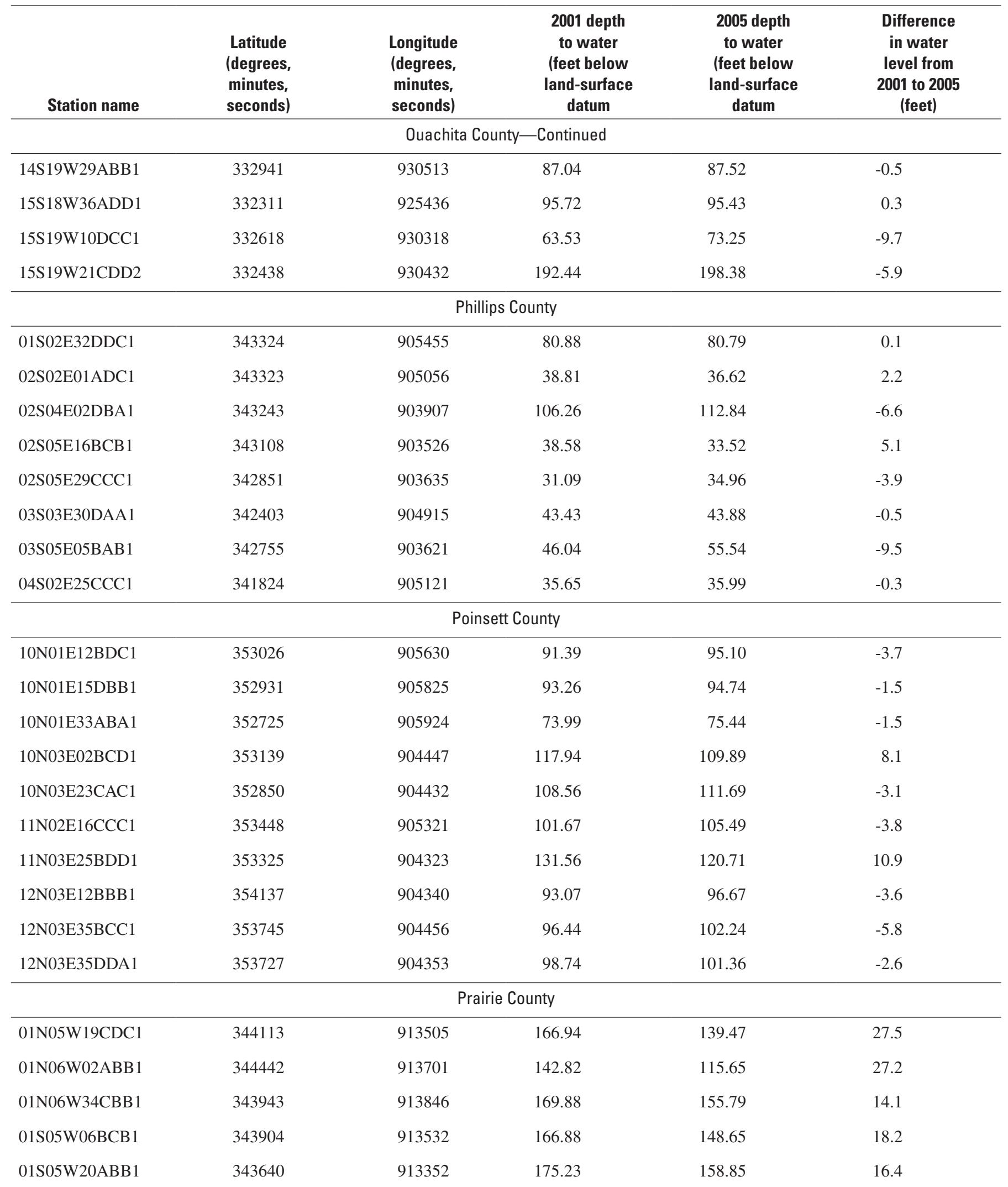


Appendix 2. Difference in water level from 2001 to 2005 in the Sparta-Memphis aquifer in Arkansas and Louisiana. —Continued

[Horizontal datum is NAD of 1983; negative values denote a decline; 2001 depth to water level (Schrader, 2004)]

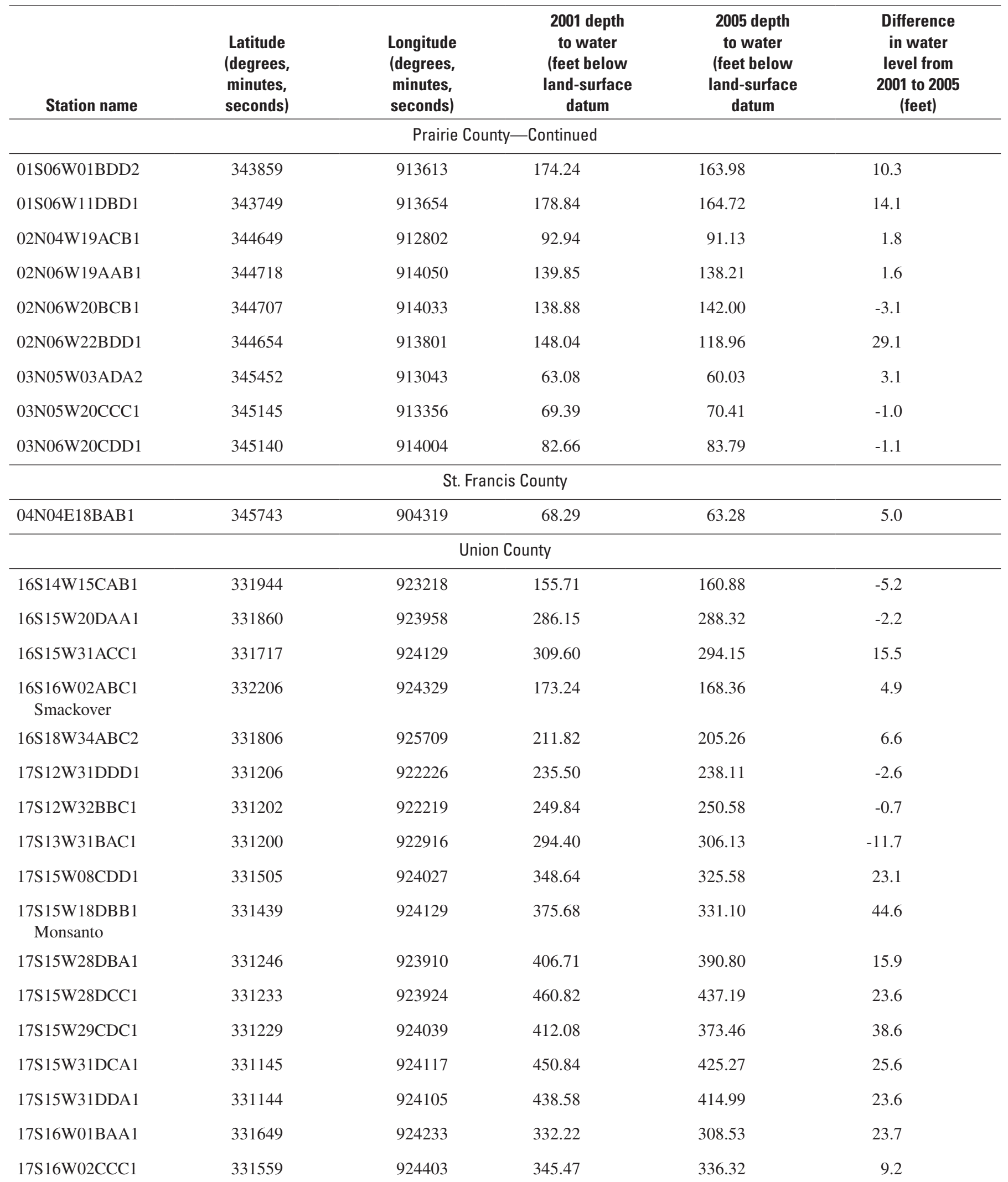


60 Status of Water Levels and Selected Water-Quality Conditions in the Sparta-Memphis Aquifer in Arkansas and the Status of Water Levels in the Sparta Aquifer in Louisiana, Spring 2005

Appendix 2. Difference in water level from 2001 to 2005 in the Sparta-Memphis aquifer in Arkansas and Louisiana. —Continued

[Horizontal datum is NAD of 1983; negative values denote a decline; 2001 depth to water level (Schrader, 2004)]

\begin{tabular}{|c|c|c|c|c|c|}
\hline Station name & $\begin{array}{c}\text { Latitude } \\
\text { (degrees, } \\
\text { minutes, } \\
\text { seconds) }\end{array}$ & $\begin{array}{c}\text { Longitude } \\
\text { (degrees, } \\
\text { minutes, } \\
\text { seconds) }\end{array}$ & $\begin{array}{c}2001 \text { depth } \\
\text { to water } \\
\text { (feet below } \\
\text { land-surface } \\
\text { datum }\end{array}$ & $\begin{array}{c}2005 \text { depth } \\
\text { to water } \\
\text { (feet below } \\
\text { land-surface } \\
\text { datum }\end{array}$ & $\begin{array}{c}\text { Difference } \\
\text { in water } \\
\text { level from } \\
2001 \text { to } 2005 \\
\text { (feet) }\end{array}$ \\
\hline \multicolumn{6}{|c|}{ Union County-Continued } \\
\hline 17S16W02DCD1 & 331602 & 924326 & 397.80 & 387.68 & 10.1 \\
\hline 17S16W24BDB1 & 331357 & 924248 & 401.68 & 394.04 & 7.6 \\
\hline 17S17W30DCD1 & 331257 & 925356 & 316.28 & 321.93 & -5.7 \\
\hline 18S12W33BBB1 & 330651 & 922120 & 136.18 & 141.18 & -5.0 \\
\hline 18S15W35DAC1 & 330636 & 923707 & 303.26 & 290.20 & 13.1 \\
\hline 18S16W10CDD1 & 331000 & 924445 & 330.09 & 327.54 & 2.5 \\
\hline 18S16W11AAB1 & 331041 & 924314 & 389.81 & 375.97 & 13.8 \\
\hline 18S16W11DAC1 & 331011 & 924316 & 431.40 & 422.53 & 8.9 \\
\hline 18S16W28BBB1 & 330809 & 924611 & 336.26 & 331.22 & 5.0 \\
\hline 18S17W22BDD1 & 330856 & 925056 & 371.20 & 353.54 & 17.7 \\
\hline 18S18W11ACD2 & 331051 & 925615 & 284.76 & 271.33 & 13.4 \\
\hline 05N01W11ABA1 & 350426 & 910407 & 55.99 & 55.76 & 0.2 \\
\hline 05N01W17DBB1 & 350311 & 910727 & 44.73 & 45.61 & -0.9 \\
\hline 05N02W31DCB3 & 350027 & 911456 & 13.55 & 11.64 & 1.9 \\
\hline 07N01W12BCB1 & 351442 & 910326 & 62.02 & 61.52 & 0.5 \\
\hline 08N01W12CDA1 & 351934 & 910311 & 75.52 & 72.04 & 3.5 \\
\hline \multicolumn{6}{|c|}{ State of Louisiana } \\
\hline \multicolumn{6}{|c|}{ Bienville Parish } \\
\hline Bi-144 & 323505 & 925350 & 238.22 & 240.35 & -2.1 \\
\hline \multicolumn{6}{|c|}{ Caldwell Parish } \\
\hline $\mathrm{Ca}-86 \mathrm{~B}$ & 320154 & 921646 & 79.96 & 82.94 & -3 \\
\hline
\end{tabular}


Appendix 2. Difference in water level from 2001 to 2005 in the Sparta-Memphis aquifer in Arkansas and Louisiana. —Continued

[Horizontal datum is NAD of 1983; negative values denote a decline; 2001 depth to water level (Schrader, 2004)]

\begin{tabular}{|c|c|c|c|c|c|}
\hline Station name & $\begin{array}{c}\text { Latitude } \\
\text { (degrees, } \\
\text { minutes, } \\
\text { seconds) }\end{array}$ & $\begin{array}{l}\text { Longitude } \\
\text { (degrees, } \\
\text { minutes, } \\
\text { seconds) }\end{array}$ & $\begin{array}{c}2001 \text { depth } \\
\text { to water } \\
\text { (feet below } \\
\text { land-surface } \\
\text { datum }\end{array}$ & $\begin{array}{c}2005 \text { depth } \\
\text { to water } \\
\text { (feet below } \\
\text { land-surface } \\
\text { datum }\end{array}$ & $\begin{array}{c}\text { Difference } \\
\text { in water } \\
\text { level from } \\
2001 \text { to } 2005 \\
\text { (feet) }\end{array}$ \\
\hline \multicolumn{6}{|c|}{ Claiborne Parish } \\
\hline Cl-111 & 324817 & 925125 & 288.47 & 290.04 & -1.6 \\
\hline Cl-136 & 323943 & 925736 & 324.27 & 326.86 & -2.6 \\
\hline Cl-148 & 325437 & 925033 & 199.74 & 199.03 & 0.7 \\
\hline Cl-149 & 330002 & 924459 & 296.68 & 292.55 & 4.1 \\
\hline Ja-49 & 321709 & 924524 & 177.86 & 167.61 & 10.3 \\
\hline Ja-147 & 322357 & 923417 & 252.59 & 254.48 & -1.9 \\
\hline Ja-148 & 321338 & 923458 & 228.7 & 230.18 & -1.5 \\
\hline \multicolumn{6}{|c|}{ Lincoln Parish } \\
\hline L-26 & 324141 & 923905 & 186.82 & 190.92 & -4.1 \\
\hline L-137 & 323319 & 923920 & 303.25 & 306.73 & -3.5 \\
\hline \multicolumn{6}{|c|}{ Morehouse Parish } \\
\hline \multicolumn{6}{|c|}{ Ouachita Parish } \\
\hline \multicolumn{6}{|c|}{ Union Parish } \\
\hline Un-26 & 324417 & 920900 & 194.23 & 195.89 & -1.7 \\
\hline Un-79 & 324955 & 920840 & 161.7 & 165.11 & -3.4 \\
\hline Un-83 & 325550 & 923916 & 174.84 & 171.17 & 3.7 \\
\hline Un-84 & 325647 & 922415 & 259.06 & 262.64 & -3.6 \\
\hline Un-86 & 325929 & 921140 & 105.95 & 111.58 & -5.6 \\
\hline Un-134 & 323655 & 922117 & 318.56 & 324.62 & -6.1 \\
\hline Un-157 & 324708 & 922310 & 254.32 & 259.13 & -4.8 \\
\hline \multicolumn{6}{|c|}{ Webster Parish } \\
\hline Wb-338 & 330040 & 931900 & 94.74 & 93.87 & 0.9 \\
\hline Wb-399 & 325518 & 932219 & 44.06 & 41.93 & 2.1 \\
\hline
\end{tabular}


62 Status of Water Levels and Selected Water-Quality Conditions in the Sparta-Memphis Aquifer in Arkansas and the Status of Water Levels in the Sparta Aquifer in Louisiana, Spring 2005

Appendix 2. Difference in water level from 2001 to 2005 in the Sparta-Memphis aquifer in Arkansas and Louisiana. —Continued

[Horizontal datum is NAD of 1983; negative values denote a decline; 2001 depth to water level (Schrader, 2004)]

\begin{tabular}{lllccc}
\hline Station name & $\begin{array}{c}\text { Latitude } \\
\text { (degrees, } \\
\text { minutes, } \\
\text { seconds) }\end{array}$ & $\begin{array}{l}\text { Longitude } \\
\text { (degrees, } \\
\text { minutes, } \\
\text { seconds) }\end{array}$ & $\begin{array}{c}\text { 2001 depth } \\
\text { to water } \\
\text { feet below } \\
\text { land-surface } \\
\text { datum }\end{array}$ & $\begin{array}{c}\text { 2005 depth } \\
\text { to water } \\
\text { (feet below } \\
\text { land-surface } \\
\text { datum }\end{array}$ & $\begin{array}{c}\text { Difference } \\
\text { in water } \\
\text { level from }\end{array}$ \\
\hline W-28 & \multicolumn{2}{c}{ Winn Parish } & & $\begin{array}{c}\text { 2001 to 2005 } \\
\text { (feet) }\end{array}$ \\
\hline W-144B & 315527 & 923708 & 58.11 & 63.35 & -5.2 \\
W-172 & 315450 & 923101 & 51.9 & 56.53 & -4.6 \\
W-179 & 320541 & 922916 & 97.78 & 100.48 & -2.7 \\
\hline
\end{tabular}


Appendix 3. Specific conductance and temperature data collected from wells completed in the Sparta-Memphis aquifer in Arkansas, spring 2005.

[ $\mu \mathrm{S} / \mathrm{cm}$, microsiemens per centimeter at 25 degrees Celsius; Horizontal datum is NAD of 1983]

\begin{tabular}{|c|c|c|c|c|c|c|c|}
\hline $\begin{array}{c}\text { Station } \\
\text { name }\end{array}$ & $\begin{array}{l}\text { Latitude } \\
\text { (degrees, } \\
\text { minutes, } \\
\text { seconds) }\end{array}$ & $\begin{array}{l}\text { Longitude } \\
\text { (degrees, } \\
\text { minutes, } \\
\text { seconds) }\end{array}$ & $\begin{array}{l}\text { Well depth } \\
\text { (feet) }\end{array}$ & Aquifer & $\begin{array}{c}\text { Date } \\
\text { sampled }\end{array}$ & $\begin{array}{c}\text { Specific } \\
\text { conductance } \\
(\mu S / \mathrm{cm})\end{array}$ & $\begin{array}{c}\text { Temperature } \\
\text { (degrees } \\
\text { Celsius) }\end{array}$ \\
\hline \multicolumn{8}{|c|}{ Arkansas County } \\
\hline 03S04W26CDA1 & 342421 & 912438 & 666 & Sparta & $04 / 18 / 2005$ & 349 & 23.6 \\
\hline 04S01W04CBD1 & 342225 & 910808 & 713 & Sparta & $04 / 15 / 2005$ & 845 & 24.0 \\
\hline 05S03W04ADB1 & 341734 & 912007 & 768 & Sparta & $04 / 14 / 2005$ & 396 & 23.7 \\
\hline 07S03W06ABC1 & 340702 & 912248 & 720 & Sparta & $04 / 14 / 2005$ & 212 & 22.9 \\
\hline \multicolumn{8}{|c|}{ Ashley County } \\
\hline 15S07W32CDD1 & 332118 & 915101 & 1,000 & Sparta & $03 / 23 / 2005$ & 875 & 24.8 \\
\hline \multicolumn{8}{|c|}{ Bradley County } \\
\hline 13S09W06ACB2 & 333647 & 920417 & 1,022 & Sparta & 03/18/2005 & 365 & 23.1 \\
\hline 13S11W17BCD1 & 333454 & 921607 & 680 & Sparta & $03 / 18 / 2005$ & 444 & 23.2 \\
\hline \multicolumn{8}{|c|}{ Calhoun County } \\
\hline 13S13W32CDA1 & 333227 & 922742 & 450 & Sparta & 03/17/2005 & 432 & 23.1 \\
\hline 14S13W12CCB1 & 333040 & 922404 & 613 & Sparta & 03/17/2005 & 446 & 23.2 \\
\hline \multicolumn{8}{|c|}{ Cleveland County } \\
\hline 09S11W01DCA1 & 335729 & 921134 & 558 & Sparta & $03 / 29 / 2005$ & 278 & 22.5 \\
\hline 10S09W35ACD1 & 334758 & 915957 & 618 & Sparta & $03 / 29 / 2005$ & 239 & 22.8 \\
\hline 11S11W16AAB1 & 334543 & 921423 & 815 & Sparta & $03 / 29 / 2005$ & 370 & 22.6 \\
\hline \multicolumn{8}{|c|}{ Columbia County } \\
\hline 17S19W15AAB1 & 331546 & 930318 & 580 & Sparta & 03/09/2005 & 354 & 24.1 \\
\hline 18S22W27DDD1 & 330835 & 932159 & 516 & Sparta & 03/09/2005 & 239 & 21.7 \\
\hline 19S23W11CDA2 & 330609 & 932744 & 385 & Sparta & 03/09/2005 & 189 & 21.2 \\
\hline \multicolumn{8}{|c|}{ Craighead County } \\
\hline 14N04E22CBD1 & 354929 & 903921 & 240 & Memphis & 04/06/2005 & 131 & 19.0 \\
\hline 14N04E28DBD1 & 354837 & 903953 & 210 & Memphis & 04/06/2005 & 158 & 21.9 \\
\hline \multicolumn{8}{|c|}{ Crittenden County } \\
\hline 06N09E23AAB1 & 350745 & 900553 & 338 & Memphis & $04 / 05 / 2005$ & 240 & 22.9 \\
\hline \multicolumn{8}{|c|}{ Cross County } \\
\hline 09N03E22ABD1 & 352404 & 904518 & 350 & Memphis & $04 / 05 / 2005$ & 340 & 25.3 \\
\hline
\end{tabular}


64 Status of Water Levels and Selected Water-Quality Conditions in the Sparta-Memphis Aquifer in Arkansas and the Status of Water Levels in the Sparta Aquifer in Louisiana, Spring 2005

Appendix 3. Specific conductance and temperature data collected from wells completed in the Sparta-Memphis aquifer in Arkansas, spring 2005. - Continued

[ $\mu \mathrm{S} / \mathrm{cm}$, microsiemens per centimeter at 25 degrees Celsius; Horizontal datum is NAD of 1983]

\begin{tabular}{|c|c|c|c|c|c|c|c|}
\hline $\begin{array}{c}\text { Station } \\
\text { name }\end{array}$ & $\begin{array}{c}\text { Latitude } \\
\text { (degrees, } \\
\text { minutes, } \\
\text { seconds) }\end{array}$ & $\begin{array}{l}\text { Longitude } \\
\text { (degrees, } \\
\text { minutes, } \\
\text { seconds) }\end{array}$ & $\begin{array}{c}\text { Well depth } \\
\text { (feet) }\end{array}$ & Aquifer & $\begin{array}{c}\text { Date } \\
\text { sampled }\end{array}$ & $\begin{array}{c}\text { Specific } \\
\text { conductance } \\
(\mu \mathrm{S} / \mathrm{cm})\end{array}$ & $\begin{array}{c}\text { Temperature } \\
\text { (degrees } \\
\text { Celsius) }\end{array}$ \\
\hline \multicolumn{8}{|c|}{ Cross County-Continued } \\
\hline 09N04E30DCA1 & 352232 & 904218 & 1,132 & Memphis & $04 / 05 / 2005$ & 480 & 22.7 \\
\hline \multicolumn{8}{|c|}{ Dallas County } \\
\hline 07S14W31AAA & 340425 & 923334 & 545 & Sparta & 03/07/2005 & 129 & 21.1 \\
\hline 09S16W19CAA1 & 335605 & 924701 & 28.2 & Sparta & 03/07/2005 & 99.3 & 21.0 \\
\hline 10S13W34ACA2 & 334829 & 922458 & 888 & Sparta & 03/07/2005 & 269 & 24.0 \\
\hline \multicolumn{8}{|c|}{ Desha County } \\
\hline 09S02W26AAC1 & 335346 & 911521 & 626 & Sparta & $03 / 24 / 2005$ & 260 & 22.5 \\
\hline 10S04W11CBC1 & 335034 & 912905 & 830 & Sparta & $03 / 24 / 2005$ & 253 & 25.6 \\
\hline 12S03W26CBB1 & 333749 & 912259 & 819 & Sparta & $03 / 24 / 2005$ & 385 & 24.4 \\
\hline \multicolumn{8}{|c|}{ Drew County } \\
\hline 12S06W30BBD1 & 333807 & 914543 & 779 & Sparta & $03 / 23 / 2005$ & 287 & 23.0 \\
\hline 13S05W36ACB1 & 333151 & 913408 & 692 & Sparta & $03 / 23 / 2005$ & 343 & 22.3 \\
\hline \multicolumn{8}{|c|}{ Grant County } \\
\hline 05S13W03CAA1 & 341844 & 922400 & 569 & Sparta & $04 / 20 / 2005$ & 93.4 & 21.0 \\
\hline 05S14W06DCC1 & 341843 & 923327 & 370 & Sparta & $04 / 21 / 2005$ & 107 & 21.8 \\
\hline 05S15W05ABD1 & 341924 & 923827 & 190 & Sparta & $04 / 21 / 2005$ & 64.4 & 19.4 \\
\hline 06S15W26ACA1 & 341022 & 923538 & 172 & Sparta & $04 / 20 / 2005$ & 50.0 & 18.6 \\
\hline \multicolumn{8}{|c|}{ Jefferson County } \\
\hline 03S11W22ABC1 & 342651 & 921058 & 707 & Sparta & $04 / 13 / 2005$ & 91.0 & 22.0 \\
\hline 04S07W17BCC1 & 342140 & 914742 & 756 & Sparta & $04 / 12 / 2005$ & 153 & 22.7 \\
\hline 04S11W14BAD1 & 342220 & 921000 & 854 & Sparta & $04 / 13 / 2005$ & 93.2 & 22.8 \\
\hline 05S10W16DBD & 341635 & 920534 & 865 & Sparta & $04 / 12 / 2005$ & 161 & 20.7 \\
\hline \multicolumn{8}{|c|}{ Lafayette County } \\
\hline 19S23W29BDB1 & 330352 & 933103 & 250 & Sparta & 03/08/2005 & 397 & 24.2 \\
\hline \multicolumn{8}{|c|}{ Lee County } \\
\hline 03N03E28CDB1 & 345006 & 904749 & 591.5 & Sparta & $04 / 04 / 2005$ & 1,356 & 20.5 \\
\hline \multicolumn{8}{|c|}{ Lincoln County } \\
\hline 07S07W30CDC1 & 340444 & 915043 & 1,350 & Sparta & $04 / 11 / 2005$ & 220 & 28.3 \\
\hline
\end{tabular}


Appendix 3. Specific conductance and temperature data collected from wells completed in the Sparta-Memphis aquifer in Arkansas, spring 2005. - Continued

[ $\mu \mathrm{S} / \mathrm{cm}$, microsiemens per centimeter at 25 degrees Celsius; Horizontal datum is NAD of 1983]

\begin{tabular}{|c|c|c|c|c|c|c|c|}
\hline $\begin{array}{c}\text { Station } \\
\text { name }\end{array}$ & $\begin{array}{c}\text { Latitude } \\
\text { (degrees, } \\
\text { minutes, } \\
\text { seconds) }\end{array}$ & $\begin{array}{c}\text { Longitude } \\
\text { (degrees, } \\
\text { minutes, } \\
\text { seconds) }\end{array}$ & $\begin{array}{c}\text { Well depth } \\
\text { (feet) }\end{array}$ & Aquifer & $\begin{array}{c}\text { Date } \\
\text { sampled }\end{array}$ & $\begin{array}{c}\text { Specific } \\
\text { conductance } \\
(\mu \mathrm{S} / \mathrm{cm})\end{array}$ & $\begin{array}{c}\text { Temperature } \\
\text { (degrees } \\
\text { Celsius) }\end{array}$ \\
\hline \multicolumn{8}{|c|}{ Lincoln County-Continued } \\
\hline 08S05W35ACC1 & 335907 & 913337 & 836 & Sparta & $04 / 11 / 2005$ & 245 & 25.9 \\
\hline 08S08W35DBB1 & 335858 & 915222 & 974 & Sparta & $04 / 11 / 2005$ & 198 & 26.3 \\
\hline 08S08W35DCB1 & 335851 & 915217 & 1,062 & Sparta & $04 / 11 / 2005$ & 193 & 22.3 \\
\hline 09S07W07DAD1 & 335634 & 915128 & 1,052 & Sparta & $04 / 11 / 2005$ & 420 & 24.6 \\
\hline \multicolumn{8}{|c|}{ Monroe County } \\
\hline 01N03W14CCB1 & 344144 & 911801 & 595 & Sparta & $03 / 31 / 2005$ & 893 & 20.2 \\
\hline 04N02W30BAD1 & 345617 & 911515 & 285 & Memphis & $03 / 31 / 2005$ & 777 & 18.3 \\
\hline \multicolumn{8}{|c|}{ Nevada County } \\
\hline 14S21W04CCB1 & 333251 & 931708 & 210 & Sparta & 03/08/2005 & 205 & 20.1 \\
\hline 14S21W20AAB1 & 333050 & 931723 & 190 & Sparta & 03/08/2005 & 194 & 20.2 \\
\hline \multicolumn{8}{|c|}{ Ouachita County } \\
\hline 12S19W14AAA1 & 334143 & 930105 & 60 & Sparta & 03/17/2005 & 32.7 & 17.9 \\
\hline 13S19W28BCD1 & 333434 & 930418 & 52 & Sparta & $03 / 22 / 2005$ & 56.3 & 20.5 \\
\hline 15S18W36ADD1 & 332311 & 925436 & 220 & Sparta & $03 / 22 / 2005$ & 382 & 20.9 \\
\hline 15S19W10DCC1 & 332618 & 930318 & 375 & Sparta & $03 / 23 / 2005$ & 191 & 20.3 \\
\hline \multicolumn{8}{|c|}{ Phillips County } \\
\hline 02S02E01ADC1 & 343323 & 905056 & 686 & Sparta & $03 / 31 / 2005$ & 985 & 20.7 \\
\hline 03S05E05BAB 1 & 342755 & 903621 & 514 & Sparta & $03 / 31 / 2005$ & 782 & 18.9 \\
\hline 04S02E25CCC1 & 341824 & 905121 & 930 & Sparta & $03 / 31 / 2005$ & 1,240 & 22.0 \\
\hline \multicolumn{8}{|c|}{ Poinsett County } \\
\hline 11N03E25BDD1 & 353325 & 904323 & 250 & Memphis & 04/06/2005 & 401 & 19.3 \\
\hline \multicolumn{8}{|c|}{ Prairie County } \\
\hline 02N04W19ACB1 & 344649 & 912802 & 482 & Sparta & $03 / 31 / 2005$ & 349 & 19.1 \\
\hline \multicolumn{8}{|c|}{ Union County } \\
\hline 16S15W20DAA1 & 331860 & 923958 & 603 & Sparta & 03/15/2005 & 553 & 23.7 \\
\hline 16S18W34ABC2 & 331806 & 925709 & 465 & Sparta & 03/15/2005 & 338 & 21.7 \\
\hline 18S14W06CCD1 & 331039 & 923531 & 783 & Sparta & $03 / 15 / 2005$ & 742 & 23.4 \\
\hline 18S16W11DAB1 & 331011 & 924316 & 767 & Sparta & 03/15/2005 & 536 & 23.1 \\
\hline
\end{tabular}


66 Status of Water Levels and Selected Water-Quality Conditions in the Sparta-Memphis Aquifer in Arkansas and the Status of Water Levels in the Sparta Aquifer in Louisiana, Spring 2005

Appendix 3. Specific conductance and temperature data collected from wells completed in the Sparta-Memphis aquifer in Arkansas, spring 2005. - Continued

[ $\mu \mathrm{S} / \mathrm{cm}$, microsiemens per centimeter at 25 degrees Celsius; Horizontal datum is NAD of 1983]

\begin{tabular}{|c|c|c|c|c|c|c|c|}
\hline $\begin{array}{c}\text { Station } \\
\text { name }\end{array}$ & $\begin{array}{c}\text { Latitude } \\
\text { (degrees, } \\
\text { minutes, } \\
\text { seconds) }\end{array}$ & $\begin{array}{l}\text { Longitude } \\
\text { (degrees, } \\
\text { minutes, } \\
\text { seconds) }\end{array}$ & $\begin{array}{c}\text { Well depth } \\
\text { (feet) }\end{array}$ & Aquifer & $\begin{array}{c}\text { Date } \\
\text { sampled }\end{array}$ & $\begin{array}{c}\text { Specific } \\
\text { conductance } \\
(\mu S / \mathrm{cm})\end{array}$ & $\begin{array}{c}\text { Temperature } \\
\text { (degrees } \\
\text { Celsius) }\end{array}$ \\
\hline \multicolumn{8}{|c|}{ Woodruff County } \\
\hline 05N02W31DCB1 & 350028 & 911456 & 250 & Memphis & 04/04/2005 & 183 & 19.6 \\
\hline
\end{tabular}




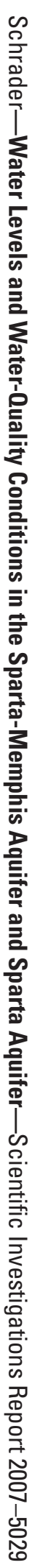

8 Printed on recycled paper 